\title{
ACADEMIC FREEDOM AND THE FIRST AMENDMENT IN THE SUPREME COURT OF THE UNITED STATES: AN UNHURRIED HISTORICAL REVIEW
}

\author{
William W. Van Alstyne*
}

\section{INTRODUCTION}

In 1940, the American Association of University Professors ("AAUP") and the Association of American Colleges ("AAC") put forth their 1940 Statement of Principles on Academic Freedom and Tenure. ${ }^{1}$ In the half century since its original issuance, the 1940 Statement has become well known in higher education in the United States, and its principles of academic freedom are widely observed. It has been incorporated expressly or by reference into many faculty handbooks in American colleges and universities, endorsed by more than one hundred national learned and professional associations, and relied upon in a number of state and federal courts. It is, overall, the general norm of academic practice in the United States.

As a general legal proposition, however, the 1940 Statement is an example of very soft law. Generally speaking, the 1940 Statement is not policed by courts. Rather, it is policed principally by Committee A of the AAUP ${ }^{2}$ and by publication of AAUP's ad hoc committee investigation case reports in the AAUP's professional journal. And while this may understate the 1940 Statement's influence in some respects (for example, as when a university has adopted it and made it part of the faculty's contractual guarantee), the 1940 Statement is certainly not hard law in the ultimate sense one differently associates, say, with the first amendment to the Constitution with its general protection of free speech. That fixed constitutional provision, even if limited

Copyright $\odot 1990$ by Law and Contemporary Problems

- William R. Perkins Professor of Law, Duke University School of Law; Past President and General Counsel, American Association of University Professors.

1. 1940 Statement of Principles on Academic Freedom and Tenure ("1940 Statement") in Policy Documents and Reports 3 (AAUP, 1984) ("1984 Red Book"); see Appendix B, 53 L \& Contemp Probs 407 (Summer 1990).

2. For an explanation of the function of Committee A, see generally Louis Joughin, ed, Academic Freedom and Tenure: A Handbook of the American Association of University Professors (Univ of Wis Press, 1967). 
to acts of government, as it is, ${ }^{3}$ is at the opposite end of the legal order from the precatory law of the AAUP and AAC. In comparison with the soft law of the 1940 Statement, the first amendment is hard law indeed. The 1940 Statement instructs institutions of higher education respecting the kind of disposition they ought, in the opinion of the Statement's sponsoring and endorsing learned societies, to take toward academic freedom. As already noted, however, the 1940 Statement generally requires affirmative institutional action of some sort to carry its provisions into legal effect (for example, incorporation by reference into college or university bylaws, into letters of faculty appointment, or collective bargaining agreements). No such step is required in respect to the first amendment, of course. The Bill of Rights, including the first amendment, is quite different from the 1940 Statement. The first amendment is, after all, part of our fundamental law. Compliance, therefore, is not optional; its protections are enforceable in every court in the United States.

Even so, the first amendment is in its own way very much like the 1940 Statement: the first amendment's immediate use value is in large measure derived from the case law that has grown up around it, as has happened also with the 1940 Joint Statement and Committee A. What the courts understand the first amendment to say, rather than what one may otherwise suppose it provides, tends necessarily to occupy the main ground in working through its various applications and use. Given the role courts have occupied in the American constitutional order at least since Marbury $v$. Madison ${ }^{4}$ was decided in 1803, the case law of the first amendment provides the basic, though not exclusive, road map in tending to guide first amendment disputes. The AAUP's Committee A case law (that is, the very large body of published case

3. The first amendment provides: "Congress shall make no law respecting an establishment of religion, or prohibiting the free exercise thereof; or abridging the freedom of speech, or of the press; or of the right of the people peaceably to assemble, and to petition the Government for a redress of grievances." As suggested by its language, the first amendment is not addressed to the states. The Supreme Court confirmed that impression in 1833. Barron $v$ Mayor and City Council, 32 US (7 Pet) 243, 247-51 (1833) (The Bill of Rights was proposed and ratified as a set of affirmative restrictions on the national government only; it has no application to the states.). With the ratification of the 14 th amendment in 1868, arguments came to be advanced that the 14 th amendment incorporated some of the protections the Bill of Rights had furnished against the national government as restraints equally binding thereafter on the states. (For one recent and elaborate review of this subject, see Michael K. Curtis, No State Shall Abridge: The Fourteenth Amendment and the Bill of Rights (Duke Univ Press, 2d ed 1987)). In 1925, the Supreme Court accepted that view in respect to the first amendment, in dicta. Gitlow $v$ New York, 268 US 652, 666 (1925). In 1931, the identification of the full free speech and free press clause to the due process clause of the 14 th amendment was employed by the Court to hold invalid a state law. See Near v Minnesota, 283 US 697, $701-33$ (1931). See also DeJonge v Oregon, 299 US 353, 356-66 (1937). Since that date, the 14th and first amendments have been treated by the Supreme Court as framing parallel, binding restrictions on the national and state governments, although neither by itself applies to private entities not operating as agencies of the state.

4. 5 US (1 Cranch) 137 (1803). Marbun affirmed the Supreme Court's pivotal role in applying the Constitution, much as Bishop Hoadley had addressed the pivotal role of judges in England in his sermon preached before the King in 1717 ("Whoever hath an absolute authority to interpret any written or spoken laws, it is he who is truly the lawgiver, to all intents and purposes, and not the person who first spoke or wrote them."). See William B. Lockhart, et al, Constitutional Law: CasesComments-Questions 1 (West, 6th ed 1986). 
reports that used to appear in the AAUP Bulletin and that now appear in the AAUP's publication Academe) has functioned informally in an equivalent fashion in respect to the 1940 Statement. This informal case law has provided specific clarification and application of that fifty-year-old, two-page declaration. Roughly speaking, albeit of course at a much softer level of authority, Committee A has provided the guiding case law of academic freedom identified with the 1940 Statement comparable to that provided by the Supreme Court.

However, there is no reason a priori to expect these two bodies of case law to share any substantial common ground. Rather, the more reasonable assumption would be that the Supreme Court case law of the first amendment and the informal Committee A case law of the 1940 Statement would move along separate, even if roughly parallel, paths: the first dealing with large matters of free speech, government censorship, and government power to punish what people say, the second dealing with academic freedom as a tight bundle of interests distinct unto itself. In fact, however, this is not quite true. Rather, while the first amendment and the 1940 Statement are indeed differently grounded, their case law has tended very substantially to overlap. In fact, a large portion of the previously purely soft law of academic freedom has found a niche in the hard law of the Constitution through the usages of academic freedom in the Supreme Court. It is this process we shall shortly follow in an unhurried review.

Beyond this major, largely post-World War II development, moreover, the Supreme Court has also taken some of the values narrowly represented in the 1940 Statement and expanded upon them in a variety of ways. For example, the 1940 Statement addressed itself to academic freedom as an imperative in higher education. Consistent with some trends in first amendment case law, however, academic freedom has secured some purchase for public school teachers as well. As a different example, whereas "academic freedom" is defined in the 1940 Statement as the "[f]reedom of teaching" (and of faculty research and faculty extramural activities of certain kinds), ${ }^{5}$ some Court decisions speak of academic freedom in respect to students, and not solely those who teach. As still a third example, although academic freedom is usually treated (in the 1940 Statement) as a matter of individual freedom, usually that of individual teachers to address matters of professional interest without threat to their jobs, ${ }^{6}$ some Court decisions apply a first amendment notion of academic freedom much more corporately, that is, to the university or the college as an entity. The university, it is thought, may claim a certain corporate academic freedom to set its own institutional course-in

5. Of which more mention will be made later on. See, for example, note 112 and accompanying text.

6. The standard dictionary definition is of this sort. See, for example, American Heritage Dictionary 70 (Houghton-Mifflin, 1985) ("academic freedom" defined as: "Liberty to pursue and teach relevant knowledge and to discuss it freely without restriction from school or public officials or from other sources of influence"). 
curriculum, in admissions, in appointments-sheltered from government to some degree as a matter of constitutional (academic freedom) right.

Conversely, however, even in respect to these examples, the pathway of academic freedom's definitional development has tended to be a two-way street; in some measure these developments have taken place equally within the AAUP as within the doctrines of the Supreme Court. So, for instance, while the AAUP has not attempted to police its newer Joint Statement in the same case law investigating-and-reporting manner Committee A employs for the 1940 Statement (its resources are too limited to do so), the AAUP nonetheless did help fashion a Joint Statement on Rights and Freedoms of Students in 1967.7 So, too, the AAUP has involved itself in matters of institutional academic freedom and diversity, and has appeared a substantial number of times to support the claims of first amendment academic freedom by public school teachers. The AAUP's own notions of the varieties of academic freedom, like the notions of the Supreme Court, have become more complex over time. Indeed, the AAUP's Policy Documents and Reports, the "Red Book" (its collection of basic policy statements and documents), addresses a far broader range of subjects than those just touched upon. The Red Book currently collects 179 pages of policy statements and documents: 177 pages more, that is, than the original two-page 1940 Statement presumed to do. The phrase "academic freedom" has thus become one of extended usage for the AAUP as well as for courts interpreting and applying the first amendment during the past half century or so.

Nonetheless, it is principally the latter-the usages of academic freedom in the Supreme Court-we mean to trace, rather than the formulations of the AAUP. To do that most usefully, however, we do not begin with the Supreme Court's modern decisions, but with its past decisions. Not by chance, they are linked to the origins of the AAUP.

Linking Academic Freedom to the First Amendment: A Short, Historical SKetch

A

At the turn of the twentieth century, the first amendment was virtually in a state of pre-history so far as academic freedom was concerned. Indeed, academic freedom to one side, the first amendment had no real immediate significance for free speech in general, never mind anything more specialized or arcane as Lehrfreiheit ("freedom to teach") or Lernfreiheit ("freedom to learn"), in the United States.

The first amendment had no general bite in 1900 because of the American judiciary's extremely cramped view of the amendment's scope. Despite its unqualifiedly strong language ("Congress shall make no law abridging the

7. AAUP et al, Joint Statement on Rights and Freedoms of Students, in Policy Documents and Reports 153 (AAUP, 1990) ("1967 Statement"); see Appendix C, 53 L \& Contemp Probs 411 (Summer 1990). 
freedom of speech or of the press" 8 ), the amendment was deemed to furnish no more than fig leaf protection from anything other than certain kinds of governmentally imposed licensing or permit systems. In a word, the amendment applied almost solely to some few forms of prior restraint.

The prevailing Supreme Court jurisprudence of the first amendment amounted to little more than a restatement of William Blackstone's eighteenth century Commentaries on the Laws of England, ${ }^{9}$ predating the Constitution and the first amendment. Blackstone, summarizing the common law of the eighteenth century, reported approvingly that restrictions on speech having any bad tendency in the view of public authority were quite commonplace. Other than restrictions involving some sort of press licensing system of the sort abandoned in England in 1691, Blackstone noted, it was thought to be pretty much up to Parliament and the customs of England to decide what kinds of speech might or might not be allowed. In a word, the freedom of the press (and so, too, of speech) was its freedom from having to satisfy crown censors. It was not a freedom from criminal or civil sanctions, imposed after the fact in light of the scandal of one's actual remarks.

Most judicial interpretations of the first amendment adhered sedulously to Blackstone-they enacted Blackstone's Commentaries into constitutional law. The usual judicial assumption was that the freedom of speech and of the press that the first amendment protected from abridgments by Congress was merely that freedom familiarly allowed at common law and nothing more. This view is accurately captured in a much-quoted dictum by Justice Holmes, writing for the Supreme Court in 1907: "[T] he main purpose of such constitutional provisions is 'to prevent all such previous restraints upon publications as had been practiced by other governments,' and they do not prevent the subsequent punishment of such as may be deemed contrary to the public welfare." 10 This extremely narrow interpretation of the first amendment (and, incidentally, equally of the fourteenth amendment-it is the latter that is applicable to the states), left the amendment practically useless. And so far as academic freedom might be an issue as a subset of freedom of speech, there was even more to be discouraged about.

The additional source of discouragement developed separately from a strand of constitutional analysis specially applicable to employment relationships, including public employment (that is, employment by the state). All employers were deemed to be unconstrained by the Constitution insofar as they might require that one suspend one's freedom of speech as a

8. Compare, for example, US Const, 4 th amend (forbidding only unreasonable searches and seizures). In most constitutions that contain free speech and free press clauses, the rights are heavily qualified. See, for example, article 100 of the Norwegian Constitution (second oldest after the United States Constitution, adopted in 1814) (freedom of publication protected unless it expresses "contempt of religion [or] morality," in which case it is not).

9. See Edward Christian, ed, Blackstone's Commentaries, Book 4 (Of Public Wrongs) 150-53 (Robert H. Small, 1825).

10. Patterson v Colorado, 205 US 454, 462 (1907) (first emphasis in original; second emphasis added). 
condition of holding an appointment or job. The law (that is, the body of constitutional law applicable to this subject) was only too clear: when a speech restriction limiting what one might say or write was set forth in advance as a condition of one's employment, it was not thought to raise a first amendment question at all. One was free to accept the position or not, on the terms offered; if one accepted, one was accordingly bound.

This view, too, is reflected in a case decided by Holmes in 1892, while he was still serving on the Massachusetts Supreme Court. Dismissing the appeal of a New Bedford policeman who had been fired following some public remarks critical of how the department was run, Holmes drew a distinction that was to have a lasting effect:

The petitioner may have a constitutional right to talk politics, but he has no constitutional right to be a policeman. There are few employments for hire in which the servant does not agree to suspend his constitutional right of free speech, as well as of idleness, by the implied terms of his contract. The servant cannot complain, as he takes the employment on the terms which are offered him. ${ }^{11}$

Holmes hedged only trivially on the distinction. In dicta, he suggested that if the conditions thus imposed incidentally to public employment were unreasonable in some extreme sense (that is, that the conditions seemed utterly gratuitous), the courts might intervene on substantive due process grounds. Seldom, however, would that extreme instance be deemed to have occurred; indeed, Holmes gave no example of what he had in mind.

Plainly, these views and precedents would leave any claim of mere academic freedom stranded as a constitutional matter; indeed, they left freedom of speech stranded at large. And, in fact, these views of the first and fourteenth amendments carried over for decades into the twentieth century, as a large number of cases would show.

Blackstone's bad tendency test held sway under the first amendment until well after World War I. ${ }^{12}$ The add-on employment waiver rationale was applied by the courts until well after World War II. ${ }^{13}$ It will serve our purpose here to note one famous case particularly on point-the original Scopes Monkey Trial case ${ }^{14}$ in which Clarence Darrow and Arthur Garfield Hayes argued quite vainly on the constitutional issue in the Tennessee Supreme Court in 1927.

At issue in Scopes was whether John Scopes, a Tennessee public high school teacher, could be fined or jailed for teaching "any theory that denie[d] the story of the divine creation of man as taught in the Bible," in violation of a state statute governing his conduct as a teacher in the Tennessee public schools. ${ }^{15}$ Could he discuss the theory that man may have developed not all

11. McAuliff $v$ Mayor of New Bedford, 155 Mass 216, 220, 29 NE 517, 518 (1892).

12. For a useful review, see generally David M. Rabban, The First Amendment in Its Forgotten Years, 90 Yale L J 514 (1981)

13. See, for example, Bailey v Richardson, 182 F2d 46 (DC Cir 1950), aff'd by an equally divided Court, 341 US 918 (1951).

14. Scopes $v$ State, 154 Tenn 105, 289 SW 363 (1927).

15. 154 Tenn at $108,289 \mathrm{SW}$ at 364 . The statute, incidentally, was not limited to public school teachers. Rather, it applied to "all the Universities, Normals and all other public schools supported in 
at once in perfect form, as a creation of God, but over time, from earlier life forms through the cumulative effects of mutation, reproduction, and natural selection, as Darwin had proposed? The statute gave fair warning that he could not. Violations, moreover, were punishable as a crime (apart from providing grounds for dismissal). Scopes was duly convicted and fined following a full jury trial.

Scopes' criminal conviction was in fact reversed in the state supreme court because of a technical sentencing error committed in the trial court; since Scopes agreed to leave the state, there was no subsequent reprosecution or appeal. But in reversing, the Tennessee Supreme Court left no doubt about the futility of arguing any constitutional objections to the act, whether as applied to a public school teacher or to a state university professor:

[Scopes] was under contract with the State to work in an institution of the State. He had no right or privilege to serve the State except upon such terms as the State prescribed. His liberty, his privilege, his immunity to teach and proclaim the theory of evolution, elsewhere than in the service of the State, was in no wise touched by this law.

The Statute before us is not an exercise of the police power of the State undertaking to regulate the conduct and contracts of individuals in their dealings with each other.[ $\left.{ }^{16}\right]$ On the other hand it is an Act of the State as a corporation, a proprietor, an employer. It is a declaration of a master as to the character of work the master's servant shall, or rather shall not, perform. In dealing with its own employees engaged upon its own work, the state is not hampered by the limitations of . . . the Fourteenth Amendment to the Constitution of the United States. ${ }^{17}$

Between the general bad tendency test on the one hand, and the additional doctrine represented by Scopes (that the state is not hampered by the fourteenth amendment in directing the work of its appointees and staff), very little by way of protected free speech was left unaccounted for, to say nothing of academic freedom as such. To be sure, as we have noted, private schools and private universities (that is, those not receiving public monies) could choose to provide for something roughly called "academic freedom," if they wished. That would be up to them. ${ }^{18}$ But even insofar as it was up to them, obviously the issue would turn on trustee tolerance-to control or not control what its faculty might do-and nothing else. It was not a matter of first amendment law.

whole or in part" by public funds. Tennessee Anti-Evolution Act, 1925 Tenn Pub Acts 27 (emphasis added).

16. If the statute had been extended to reach teachers in private schools and private colleges, however, it is not clear they would have fared any better than Scopes in a free speech claim. Remember that at this time the first amendment standard of judicial review would require the court to examine the restrictive state law solely under the prevailing bad tendency test. Under that test the state would need to show only that some not unreasonable view of public welfare would be advanced by forbidding such teaching, whether or not it was acceptable to the private school or college. But see Meyer v Nebraska, 262 US 390 (1923), and Bartels v lowa, 262 US 404 (1923) (further discussed in notes 24-33 and accompanying text).

17. Scopes, 154 Tenn at 109-12, $289 \mathrm{SW}$ at 364-65 (emphasis and brackets added).

18. Under the prevailing bad tendency first amendment test, however, and despite the dicta of the Tennessee Supreme Court, even this statement may be too broad. See the brief discussion in note 16. 
Throughout this period, however, significant developments in shaping academic freedom nonetheless took place. What academic freedom required was some compelling justification, at least as a strongly defensible professional imperative in higher education, even if (perhaps especially if) there was no immediate prospect of finding support in hard law.

Part of that case had already been made over decades, indeed over centuries, of course; in some measure academic freedom was already reflected in the practices of a number of institutions in the United States. Part of it was developed with a new spirit from the impact of writings such as John Stuart Mill's already classic Essay on Liberty ${ }^{19}$ published in 1859, whose chapter on "Liberty of Thought and Discussion" would eventually also influence the Supreme Court. Part could be (and was) adapted from earlier sources (for example, "The Areopagitica," 20 Milton's essay of 1643, urging the usefulness of permitting "truth and falsehood" to grapple without press censorship), and even earlier discourses on the freedom of the mind as well.

But freedom of the mind and freedom of speech had always had their limits, as Milton as well as Blackstone noted (and approved), including limits public bodies enacted for reasons they deemed socially worthwhile. If writings such as Mill's were felt to be interesting and provocative, many also thought them naive and oblivious to other interests that might more dearly matter. To many, moreover, there seemed little reason to grant academics more latitude than anyone else. As Glenn Morrow was to explain years later:

The justification of academic freedom cannot be based merely on the right to freedom of thought and expression enjoyed by all citizens of a liberal society, for academic freedom implies immunity to some natural consequences of free speech that the ordinary citizen does not enjoy. . . . The justification of academic freedom must therefore be sought in the peculiar character and function of the university scholar [if it is to be found at all]. ${ }^{21}$

In the general view of freedom of speech, one will recall, the bad tendency test was applied. Insofar as trustees, philanthropists, and others concerned with colleges and universities-whether private or public-might feel a duty to disallow teaching, research, or publication contrary to common notions of truth, faith, order, and good taste, nothing in general legal philosophy or first amendment jurisprudence provided any reason for self-restraint. There was, that is, very little reason to accept any self-denying ordinance of noninterference, whether one was a legislator or a trustee. To stand aloof in either role might merely imply an effete indifference to the public good. Viewed this way, noninterference would constitute the irresponsible stance.

An answering rationale needed to come, as Morrow suggested, from an enlarged notion of what one deems to be the public good of a university,

19. See Philip Wheelwright, ed, Jeremy Bentham, James Mill, J.S. Mill: Selected Writings (Doubleday, 1935).

20. See Don W. Wolfe, ed, 2 Complete Prose Works (Yale Univ Press, 1982).

21. Glenn R. Morrow, Academic Freedom, in David L. Sills, ed, International Encyclopedia of the Social Sciences 4, 6 (MacMillan \& Free Press, 1968). 
whether public or private: that is, of what a university should be doing, and what defines the duties (never mind the rights) of its faculty. Borrowed only partly from English universities, the developments being shaped gained ground in the United States more substantially from the example of particular German research institutes, in which a number of American scholars received their graduate education and in which Lehrfreiheit was already an established and familiar term. ${ }^{22}$

A faculty, especially a research faculty, is employed professionally to test and propose revisions in the prevailing wisdom, not to inculcate the prevailing wisdom in others, store it as monks might do, or rewrite it in elegant detail. Its function is primarily one of critical review: to check conventional truth, to reexamine ("re-search") what may currently be thought sound but may be more or less unsound. Its purpose is likewise to train others to the same critical skills. Such a faculty inquires-as an obvious sort of example-whether original and seemingly authoritative sources have been mistranslated or misunderstood. Such a faculty likewise labors to enlarge the field of experimental data and to make itself useful by publishing the results. It seeks through its own sets of disciplines and conventions to examine its own culture's characteristics as well as those of other societies, past and present, even as an outsider would be prepared to examine them, that is, without special affection or predisposition of the sort likely to cloud the integrity of the work. Its successes in these endeavors are the measure of its chief work, and also of its most important social assignment. This is what a professional faculty is meant to do. Much like the office of devil's advocate within a church (that, while faithful, desires also not to confer sainthood unrigorously and so charges someone to check itself from error), universities are licensed truthhunters defined and bound by academic freedom. As Arthur Lovejoy (a founder of the AAUP in 1913) observed in the 1930 edition of the Encyclopaedia of the Social Sciences, the ultimate social good of a university "is rendered impossible if the work of the investigator is shackled by the requirement that his conclusions shall never seriously deviate from generally accepted beliefs or from those accepted by the persons, private or official, through whom society provides the means for the maintenance of universities." 23

22. See Richard Hofstadter \& Walter P. Metzger, The Development of Academic Freedom in the United States 377-407 (Columbia Univ Press, 1955); Charles Franklin Thwing. The American and the German University: One Hundred Years of History ch 3 (Macmillan, 1928); Leo Rockwell, Academic Freedom. German Origin and American Development, 36 AAUP Bull 225-36 (1950). " Lehrfreiheil' meant that associate and full professors, who were salaried government officials working in universities supported by the state . . could determine the contents of their courses and impart the findings of their inquiries without seeking ministerial approval or fearing ministerial reproof." Matthew W. Finkin, On "Institutional" Academic Freedom, 61 Tex L Rev 817, 822 (1983), quoting Walter P. Metzger.

23. More than a half century later, in the spring of 1988 , the House of Lords adopted a bill defining academic freedom in a manner closely fiting Lovejoy's rationale ("academic freedom" proposed for the protection of teachers as "freedom within the law to question and test received wisdom, and to put forward new ideas and controversial or unpopular opinions, without placing themselves in jeopardy of losing their jobs or privileges") (emphasis added). David Walker, In a Rare Rebellion, British Lords Demand Academic-Freedom Law, in Chron Higher Educ A1, A43, col 3 (June 1, 1988). Compare 
C

Before this claim of vocational freedom could be coupled with the first and fourteenth amendments, however, a number of things needed to change. For one thing, the flaccidness of the prevailing first amendment bad tendency test would require overhaul, as would the master/servant metaphor. These changes eventually did occur (we shall shortly note how and when), but before they did, a separate development in constitutional case law took hold. We turn first to this sidebar development before resuming the tracery of first amendment doctrine in the Supreme Court. We do so because the first serious Supreme Court protection of what one might now consider academic freedom did not arise out of the first amendment at all. Rather, it came from the judicial application of pre-existing legal doctrines. The partial deliverance of academic freedom came at the hands of an activist, conservative Supreme Court defending private options against the state.

In 1920, a number of midwestern state legislatures moved to stem what they regarded as the regrettable tendency of youngsters from immigrant families to learn and speak only a foreign language rather than English. Iowa and Nebraska were among these states, and each by general statute in 1919 forbade any school instruction in any language other than English before the eighth grade.

The two cases reaching the Supreme Court testing these laws differed from Scopes, however, in that the Iowa and Nebraska laws did not limit the teaching restriction solely to the public schools; rather, they mandated English-only instruction in all private schools as well. Both cases in fact involved criminal conviction of men who taught reading German in private Lutheran schools: Robert Myer in Nebraska and August Bartels in Iowa. ${ }^{24}$ The Scopes rationale, dismissing Scopes as a mere employee confined to do the state's work on such terms as the state might decide (as master to servant), did not apply. Rather, the cases were as Scopes might have been had Scopes been a teacher in a private school, proceeding exactly as the school employed him to do, though not as the state legislature wished.

The Nebraska and Iowa statutes were not impugned on grounds of interfering with Meyer's or Bartels' first or fourteenth amendment freedom of speech, however. Nor is it easy to see how they might have been cast as free speech claims, since neither Meyer nor Bartels was affected other than as a teacher, that is, as a person for hire, furnishing foreign language instruction,

Lovejoy's definition in Edwin R. A. Seligman, ed, 1 Encyclopaedia of the Social Sciences 384 (Macmillan, 1930):

Academic freedom is the freedom of the teacher or research worker in higher institutions of learning to investigate and discuss the problems of his science and to express his conclusions, whether through publication or in the instruction of students, without interference from political or ecclesiastical authority, or from the administrative officials of the institution in which he is employed, unless his methods are found by qualified bodies of his own profession to be clearly incompetent or contrary to professional ethics.

24. See Teaching of Foreign Languages in the State of Nebraska, 1919 Neb Laws 249; Iowa Language Act, 1919 Iowa Acts 198; Meyer, 262 US at 397; Bartels, 262 US at 409. 
albeit in a privately operated school. As of the date of these cases, moreover, the Supreme Court had not even held that the first amendment necessarily applied to the states as distinct from its application to acts of Congress. That decision, identifying freedom of speech as a specific liberty equally protected against state action by the fourteenth amendment, did not come until 1925, incidental to a political sedition prosecution, Gitlow v. New York. ${ }^{25}$ Even after Gitlow, the Court still continued to apply the mere bad tendency test. ${ }^{26}$

The free speech clause was not relied upon in either case; neither did Meyer or Bartels successfully challenge the statutes on the ground that they interfered with the free exercise of religion, even though the laws dictated instructional practices of religious (Lutheran) schools. In the particular circumstances, however, it was difficult to make a free exercise claim, for in neither case was it alleged that giving or receiving instruction in German was a requirement of Lutheran faith. ${ }^{27}$

The emphasis in both Meyer and Bartels was, rather, on substantive due process principles generally. ${ }^{28}$ The Court summed up the collective effects of the Iowa and Nebraska statutes: their restriction against any private school offering any program of foreign language instruction to any student prior to the eighth grade; their antivocational restriction of teachers like Meyer and Bartels, now cut off from fulfilling teaching contracts willingly entered into by the private schools; their effective foreclosure of families from choosing any school able to teach their children anything in their own language before the eighth grade. And to what end? Certainly not as a necessary means of assuring an adequate facility in English, since that might be done by less draconian means. ${ }^{29}$ The unnecessary excess of the states' laws, merely in order to assure basic English literacy, ${ }^{30}$ was deemed to be unwarranted by any

25. 268 US 652 (1925).

26. In brief, in Gitlow the Court did make the connection firming up the equivalence of 14 th and first amendment protection; but the majority nonetheless affirmed the particular defendant's criminal conviction (by applying the first amendment's mere bad tendency test).

27. As a matter of historical interest, the first case presenting such an additional and successful claim of "free exercise" of religion did arise a few years later in Pierce y Society of Sisters, 268 US 510 (1925), where the Court relied partly on the religious freedom clause to invalidate the particular state law. In Pierce, the Court held that parents cannot be compelled to enroll their children in public, rather than parochial, schools providing additional religious instruction-assuming only that the parochial school meets reasonable minimum state educational and safety standards.

28. See also Farrington v Tokushige. 273 US 284, 298-99 (1927) (Meyer and Bartels applied in behalf of private schools similarly restricted in a federal territory, Hawaii, citing the due process clause of the fifth amendment and treating it substantively the same as the due process clause of the 14 th amendment, in Meyer.).

29. Note that the laws altogether closed off an entire area of learning freedom (Lernfreiheil) at a single stroke. The statutes did not seek their objective affirmatively, for example, by providing that children be suitably tested for English and given remedial instruction if found deficient. Rather, they operated by forbidding any foreign language instruction prior to the eighth grade, period, whether one already was well versed in English or not. See 1919 Neb Laws 249; 1919 lowa Acts 198 (cited in note 24).

30. Following so shortly on World War I, these laws were also very possibly driven in part by an anti-German animus and not solely by an unalloyed solicitude for the educational welfare of immigrant family children. 
proper police power interest. The Court reversed the criminal convictions of Meyer and Bartels.

Meyer and Bartels mark an important first boundary in our review of academic freedom. They do so by distinguishing between what the state may decide to do in its own financing (that is, its administration of public, taxfurnished educational resources) and what it may not necessarily forbid at large. The foundation of the decision was not the first amendment, but the cases are still vital to the autonomy (and academic freedom) of private universities and schools. ${ }^{31}$

Principally, the Court relied upon the 1905 case of Lochner $v$. New York, ${ }^{32}$ in which it had likewise intervened against police power claims of the welfare state. Lochner was a decision that many regarded as both infamous and wrong (Holmes dissented in Lochner, but then he also dissented in Meyer and in Bartels). Perhaps it was, yet its standard of judicial review is critical in Meyer and well worth taking into account.

In Lochner, the Supreme Court invalidated a New York law forbidding employment of persons in private commercial bakeries for more than ten hours each day. The Court struck down the law as a violation of the right of employees and employers to decide such matters for themselves At the time it was decided, Lochner was widely condemned as a judicial embrace of social Darwinism. In subsequent decades, moreover, judges practically vied with one another in denouncing its allegedly procapitalist view of the due process clause of the fourteenth amendment. ${ }^{33}$ What is relevant about the Lochner reference in Meyer, however, is the strong view it reflects respecting the role of the judiciary in applying the fourteenth amendment to protect private choice and personal liberty from the general tendency of the public welfare state. Absent that strong view of the Court's role in protecting private liberty under the fourteenth amendment, neither Meyer nor Bartels would have been decided as they were. Rather, the criminal convictions of Meyer and Bartels would have been sustained, exactly as Justice Holmes voted to do.

Although the measure of judicial review in Meyer ("activist" or "interventionist" review, as it is sometimes dismissively described) was drawn from Lochner, it would be a mistake to consider Meyer merely as of a piece with Lochner, that is, as an example of the social Darwinist thought that had already

31. See also the interesting thesis of Robert Bork in his book, The Tempting of America: The Political Seduction of the Law 47-49 (Free Press, 1990) (proposing a first amendment perspective for Meyer $v$ Nebraska insofar as the state law may have sought "to prevent the teaching of ideas not officially approved"). A noted conservative nominee to the Supreme Court, Judge Bork was opposed because his professional views of correct constitutional interpretation would repudiate the Supreme Court's jurisprudence of "substantive due process," and therefore presumably leave state governments unimpeded in enacting laws of the sort held invalid in Meyer. As his brief comments on Meyer may suggest (in this lengthy book replying to his critics), depending on the perspective one brings to the first amendment as a separate and sometimes subtle constraint on government power to induce academic conformity, the assumption may have been quite unsound.

32. 198 US 45 (1905).

33. See generally Robert G. McCloskey, Economic Due Process and the Supreme Court: An Exhumation and Reburial, 1962 Sup Ct Rev 34. 
led the Court to invalidate a large number of economic and social regulations in general. Aspects of Meyer have endured long after the demise of Lochner. They have developed separately, as a major element in academic freedom cases in the United States, though the Lochner profile of judicial review (in second-guessing economic regulations) under the fourteenth amendment has generally been abandoned by the Court.

The continuing issue foreshadowed in Meyer is the issue we noted earlier: what useful constitutional limitations are there, if any, that constrain government from superimposing its will on educational institutions to prescribe who shall (or shall not) be admitted, what shall (and shall not) be studied, and who may (and may not) teach in private as well as in public institutions? Meyer by no means settled that large question. It did, however, take the question seriously, that is, the Court submitted it to active, toughminded, substantive due process review. Moreover, at one place in its brief opinion, the Meyer majority turned to the point directly. It noticed the similarity of the laws at issue to the authoritarianism laid down in Plato's Republic: classifying the young, removing each from any family preference respecting their education, and rearing them in the image of (that is, for the best needs of) the state. In terms of academic freedom, Meyer v. Nebraska is even today a front-line constitutional case.

Indeed, Meyer is worthy of immediate juxtaposition with an earlier case in which its strong reasoning was not applied, Berea College v. Kentucky, decided by the Supreme Court in 1908. ${ }^{34}$ The decision affecting Berea College reflected no Court "activism." The state was allowed to have its way.

In the legislation that precipitated Berea College, the State of Kentucky asserted a police power interest "to preserve race identity" (the words are the state's own; I quote from the summary of its argument before the Court). ${ }^{35}$ It legislated that interest, first, by providing for racially separate public schools, then, as to private schools and colleges, by providing that each could admit either white or negro students, but not both.

As in Meyer, counsel for Berea College did not address the state law as applied to the public schools. What the state might do in structuring public education was not at issue (nor could it have been at the time, given the state of equal protection law prior to Brown $v$. Board of Education, ${ }^{36}$ still nearly a half century away). Rather, the college stressed its separate claims as an educational institution: to determine its own policies, unprepossessingly, as it wished. It likewise stressed the claims of the teachers who chose to teach there, and of its students, who evidently preferred to enroll there, not despite but because of what it was. In short, in all salient respects, the college's position was strikingly similar to the position later (and successfully) advanced in Meyer. In modern terms, it would be called a strong institutional academic freedom claim: an institutional freedom to provide such standards of

34. 211 US 45 (1908).

35. Id at 51 .

36. 349 US 294 (1954). 
admission, curriculum, and instruction as the faculty and college feel most worthy to offer those willing to seek its education, notwithstanding the state's wish to compel it to conform.

In Berea College, unlike Meyer, the Supreme Court gave the college's fourteenth amendment appeal short shrift. It sustained the state law, requiring Berea College to admit student only on the terms the state suggested, or to close its doors. As in his dissent in Meyer, Justice Holmes agreed, altogether consistently with his dour general view that neither the first nor the fourteenth amendment meant very much.

Berea College did, however, yield a dissent that is worth quoting. Justice Harlan (with Justice Day concurring in his dissent) took strong exception to the majority's weak view of the fourteenth amendment. His dissent in Berea College reads this way: "I am under the opinion that in its essential parts the statute is an arbitrary invasion of the rights of liberty and property guaranteed by the Fourteenth Amendment against hostile state action and is, therefore, void." 37 Harlan then went on to say:

The capacity to impart instruction to others is given by the Almighty for beneficent purposes and its use may not be forbidden or interfered with by Governmentcertainly not, unless such instruction is, in its nature, harmful to the public morals or imperils the public safety. . . If pupils, of whatever race-certainly, if they be citizens-choose with the consent of their parents, or voluntarily, to sit together in a private institution of learning while receiving instruction which is not in its nature harmful or dangerous to the public, no government, whether Federal or state, can legally forbid their coming together, or being together temporarily, for such an innocent purpose. ${ }^{38}$

At the same time, Justice Harlan distinguished the difference of public schools on the then conventional rationale: "Of course what I have said has no reference to regulations prescribed, for public schools, established at the pleasure of the State and maintained at the public expense."39

Even given its date (and the general state of fourteenth amendment law of that time), Berea College was a devastating decision. What the state insisted on in respect to admission and educational practice in public schools and colleges, the Court held, it could impose on others, foreclosing them from pursuing their own educational principles and ethical norms. This was not the judicial philosophy reflected in Meyer. Indeed, between the very different attitudes toward state power reflected by Meyer and by Berea College, there is no common principle obviously at work. Meyer provided an outpost of professional and institutional academic freedom Berea College was altogether denied. We shall have occasion to return to the general theme of Meyer. In the meantime, we need to pick up where we were.

37. 211 US at 67

38. Id at 67-68.

39. Id at 69 . 
D

To recapitulate briefly, we had noted, first, that successful academic freedom claims did not develop naturally or easily as an incident of early twentieth century first amendment doctrine. Rather, they developed largely without benefit of the first amendment, generally under private auspices and in response to the vacuum of doctrine associated with the first amendment as hard law. Second, we noted that beginning in 1913, the AAUP sought to gain some purchase against the law by pressing forward with the idea of the university as an institution necessarily characterized by academic freedom, in other words, in which academic freedom is inseparable from academic work. From then on, the AAUP sought to advance this characterization of higher education in the United States. And in significant measure, that effort succeeded, even while the law of the Constitution tended to lag behind.

Nevertheless, even in the 1920s, two constitutional developments (additional to Meyer) did take place in the Supreme Court, each of which was to have major effects we will trace to the present. The first was the development of the doctrine of "unconstitutional conditions"; the second was the defection of Justice Holmes (and Justice Brandeis) from the bad tendency test in favor of a more robust view of the first amendment.

1. The Collateral Doctrine of Unconstitutional Conditions. The basic doctrine of unconstitutional conditions is straightforward. Professor Tribe states it succinctly: "The . . . doctrine of 'unconstitutional conditions' holds that government may not condition the receipt of its benefits upon the nonassertion of constitutional rights even if receipt of such benefits is in all other respects a 'mere privilege'."40 The doctrine appears full-blown originally in a 1926 Supreme Court opinion by Justice Sutherland, Frost EF Frost Trucking Co.

v. Railroad Commission:

It would be a palpable incongruity to strike down an act of state legislation which, by words of express divestment, seeks to strip the citizen of rights guaranteed by the federal Constitution, but to uphold an act by which the same result is accomplished under the guise of a surrender of a right in exchange for a valuable privilege which the state threatens otherwise to withhold. . . It is inconceivable that guaranties embedded in the Constitution of the United States may be thus manipulated out of existence. ${ }^{41}$

The doctrine thus holds that government may not exploit its leverage with citizens or other persons with whom it comes into contact; it may not trade off waivers for scarce opportunities or goods it happens to control. In a word, government may not act to buy an estoppel of constitutional rights.

On its face, the doctrine strongly counters the employment waiver rationale Justice Holmes relied upon in the New Bedford policeman's case in

40. Laurence H. Tribe, American Constitutional Law 681 (Foundation Press, 2d ed 1988) (emphasis added).

41. 271 US 583, 593-94 (1926). The phrase appears in a number of earlier cases, including Doyle v Continental Ins. Co., 94 US 535, 543 (1876) (Bradley dissenting) (“[T]hough a State may have the power ... of prohibiting all foreign corporations from transacting business within its jurisdiction, it has no power to impose unconstitutional conditions upon their doing so."). 
which Holmes suggested the policeman could take the job on the terms offered or turn it down, but not have it both ways. ${ }^{42}$ Sutherland's position puts an end to that view, basically once and for all. The doctrine of unconstitutional conditions simply cuts through the policeman's agreement. It relieves him of all inappropriate terms. It does so by superintending the bargain directly; it voids any and all unconstitutional terms of the government's deal. One cannot be discharged for failing to honor a condition that should not have been presented in the first place. The doctrine frees the individual to test the substantive validity of the terms themselves; it puts the government to the test of justification and disallows the defense of contract per se.

The Frost case was more of a piece with Lochner than with academic freedom or first amendment rights: it dealt purely with business interests and an effort by a state to impose conditions of public service in exchange for a valuable advantage the state threatened otherwise to withhold (the use of state highways and roads). ${ }^{43}$ But Frost has had a modern career more significantly associated with the first amendment, and its rationale bears directly on public teachers and state university personnel. Thus, although not itself an academic freedom case, Frost assuredly supplies an important link in this unhurried review.

An excellent example of the application of Frost, though not one involving academic freedom in any strict professional usage, is provided by Pickering $v$. Board of Education, a unanimous 1968 Supreme Court decision. ${ }^{44}$ The contrast Pickering provides with New Bedford and Scopes 45 is instructive of the change that dates from the Frost case, decided in 1926.

The case was brought by Marvin Pickering, a high school teacher in Will County, Illinois. In 1964, he had sent a signed personal letter to a local newspaper. The letter was highly critical of the way the Board of Education and the district superintendent of schools had handled proposals to raise new revenue for the schools. The Board then reviewed Pickering's continuing suitability in light of his letter, in a due process hearing, and concluded that his publication of the letter was " "detrimental to the efficient operation and administration of the schools of the district." "It directed that he be dismissed. ${ }^{46}$ The case was thus similar to the New Bedford case. The outcome in the Supreme Court was not.

The Supreme Court rejected the New Bedford rationale. Insofar as the state supreme court's affirmance of Pickering's dismissal seemed partly to turn on the notion that Pickering's teaching position could be circumscribed by the

42. See note 11 and accompanying text.

43. Frost, 271 US at 589; see also notes $32-33$ and accompanying text.

44. Pickering v Board of Educ. of Township High School Dist., 391 US 563 (1968). See also Perry $v$ Sinderman, 408 US 593 (1972); Givhan v Western Line Consolidated School Dist., 439 US 410 (1979); Mt. Healthy City School Dist. Board of Educ. v Doyle, 429 US 274 (1977); Rankin v McPherson, 483 US 378 (1987). But see Connick v Myers, 461 US 138 (1983).

45. See notes 11,14 and accompanying text.

46. Pickering, 391 US at 564-65. 
requirement that he refrain from adverse public comment on the local public school administration, the Supreme Court simply demurred:

To the extent that the Illinois Supreme Court's opinion may be read to suggest that teachers may constitutionally be compelled to relinquish the First Amendment rights they would otherwise enjoy as citizens to comment on matters of public interest in connection with the operation of the public schools in which they work, it proceeds on a premise that has been unequivocally rejected in numerous prior decisions of this Court. ${ }^{47}$

The Court thus enabled Marvin Pickering to object that such a compelled agreement was void as an "unconstitutional condition." The case fits neatly within the analysis we have previously derived from Justice Sutherland's opinion in Frost.

Nevertheless, the doctrine of unconstitutional conditions, helpful as it is and significant as it has been, has also been misunderstood even in subsequent decisions of the Supreme Court. The confusions that have grown up around it result partly, though not entirely, from the wishful belief that it solves more problems than it does. Its limitation is simply a variation on the maxim that water rises no higher than its original source. Concretely, the doctrine does not instruct one in understanding whether a specific condition is unconstitutional; rather, it requires the government to show adequate justification for what it presumes to do, and to make that showing "on the merits." In brief, the doctrine declares that any answer of the sort that the petitioner (whoever the petitioner is) agreed to or at least had notice of the restriction, is never sufficient to carry the government's case. The government must defend the constitutionality of the condition on its merits, and not on the ground that it bought the right to impose the restriction.

To restate the doctrine slightly differently, it means that government cannot exempt itself from the constitutional restraints that otherwise apply to its actions merely because, were one to treat the same matter as one of private party contractual agreement, a private party would be relieved of any further obligation to continue to furnish work or pay if the other party willfully failed to observe the conditions openly attached in advance. The main point of the doctrine is that government is never a private party. Its arrangements, whatever they are, are always circumscribed by restrictions in the Constitution. These restrictions apply irrespective of the form in which the government acts, whether it acts as an employer, or as a seller or buyer of goods. They apply when it acts as administering agency of a public university, or as a provider of state or federal funds. They apply when it determines who can teach and who cannot.

In part, moreover, the doctrine of unconstitutional conditions is also a variant of two other closely related doctrines in American constitutional law regarding unconstitutional purpose in the actions of government. The point often appears in the form of a judicial statement that "what government is forbidden to do directly, it is equally forbidden to do by indirection."

47. Id at 568 . 
Sometimes it is put in terms of "the purpose and (intended) effect" of the government's act. And sometimes it is put, even as Sutherland suggested in Frost, that the government has acted to do one thing "under the guise" of doing something else. ${ }^{48}$ In the end, it comes to the same point.

Specifically, the word "guise" in the Sutherland quotation does suggest that the government is in fact acting by indirection (by some manipulative means-to adopt contract terms, waivers, contractual submission and the like) in order to achieve an end it is not entitled to seek. The very idea is thus one of overreaching for a degree of control over others the government is not otherwise permitted to assert consistent with the first amendment, but which overreaching, incorrigibly, it continues to pursue.

But this valuable point to the doctrine is also subject to its own misunderstanding if one inflates it to mean that whenever the government acts, it is always deemed to act solely for some ulterior end and never from any bona fide concern linked to the position one holds that might be sufficient to sustain the conditions attached. Such a conclusive presumption of improper purpose cannot be and in fact is not maintained in the courts. To the contrary, if the government can show a bona fide concern fairly linked to the position and the condition in question, the condition may not be a guise for anything else and may not be unconstitutional at all. Rather, if shown to be warranted by the circumstances, the condition will be sustained. Such a condition is not an unconstitutional condition. If it needs a name, moreover, there is an obvious one: call it a constitutional condition, instead. ${ }^{49}$

Under these circumstances, whatever the conditions are (and, to be sure we have not as yet said what they may be in any particular case), it will necessarily follow that one must comply with the condition or be prepared to go elsewhere. Moreover, that such conditions may have been nonnegotiable from the outset may itself make no difference at all. Obviously the government is not required to trade what it need not yield; so its

48. 271 US at 593 .

49. Consider the following example. Suppose that the Supreme Court holds that mere membership in the Communist Party or the American Nazi Party (or any other party) cannot be outlawed. Suppose a state legislature, unimpressed by the Court's view that one's choice of political affiliation is protected by the first amendment, and determined to make such affiliation as difficult as it possibly can, adopts an act making ineligible for any employment by the state-including as a state university or public school teacher-any person holding membership in the proscribed parties. The statute fits Sutherland's description of a guise in the Frost case and should be held invalid. According to our stipulation of its purpose, the legislature seeks the destruction of political parties it considers a social menace. Forbidden to act directly, it has proceeded toward the same end indirectly, by withholding "a valuable privilege" from anyone not "surrendering" his or her constitutional right. The statute is invalid under the Frost doctrine.

Suppose, however, one stipulates a different objective, namely, a concern solely for national security in respect to highly classified secrets. And suppose one substitutes a statute narrowly drawn to that end. It is not obvious that a restriction on some such kinds of access determined in part by one's political affiliations would necessarily be held unconstitutional. Of course it is possible that this statute, too, is but a guise, that is, that the claim of national security concern is a legislative fraud. Nevertheless, absent very strong evidence to that effect, it is not likely to be presumed so and, if not presumed so, such an act, narrowly drawn, may be constitutional despite its marginal effect in discouraging certain political affiliations that are otherwise a matter of first amendment "right." Compare United States v Robel, 389 US 258 (1967); Wieman v Updegraff, 344 US 183 (1952). 
unwillingness to bargain over such matters (whatever they are) is neither here nor there. The matter is, indeed, at an end.

In substance, then, the doctrine of unconstitutional conditions helps police government actions without necessarily dictating how any particular case will come out. It does so, first, by enabling the petitioner to attack the condition, rather than being treated as having waived any objection to it; and second, by then putting the government to a suitable burden of having to prove a bona fide-constitutional-objective sufficient to sustain the condition as applied to the petitioner in the manner the government proposes, or otherwise give it up. But while these are crucial benefits of the doctrine (otherwise, government could simply buy up every constitutional right by estoppel), they are ultimately inconclusive in deciding real cases. The government may be able to carry its burden of justification for the condition. The question returns us to the first amendment. What justifications are sufficient to sustain restrictions on one's speech against first amendment objections, in one's relations with government? What is the basic first amendment test? What must government show? And how does that requirement of a showing finally bear on academic freedom?

2. From "Bad Tendency" to New York Times v. Sullivan via the Dissenting Opinions of Holmes and Brandeis: The Emergence of "The Central Meaning" of Free Speech. Mr. Justice Holmes, who served on the Supreme Judicial Court of Massachusetts for twenty years and then served on the United States Supreme Court for thirty more, has been brought into this essay at every turn of the discussion. Always, until now, however, he appears as judicial bête noir, always he votes against each constitutional claim, personifying in each instance the most skeptical, narrow view of constitutional rights. In each case we have looked at thus far-Frost and Berea College as well as Patterson, New Bedford, Lochner, and Meyer-Holmes voted to sustain the state's regulation against every constitutional claim. And, quite obviously, he seems never to have championed first amendment rights.

How can it be, then, that Holmes nonetheless came to be canonized as one of the greatest Justices ever to have served on the Supreme Court? Partly, indeed perhaps largely, because his view of the first amendment-and of the central meaning of freedom of speech-fundamentally and finally changed. ${ }^{50}$ Holmes was almost certainly the most philosophically inclined judge ever to occupy a seat on the Supreme Court. And, after two decades on the Court, he began to write altogether different kinds of epigrams than the sort he had authored in 1892; new epigrams very much like these: "The United States may give up the Post Office when it sees fit, but while it carries it on the use of the mails is almost as much a part of free speech as the right to use our

50. See David M. Rabban, The Emergence of Modern First Amendment Doctrine, $50 \mathrm{U}$ Chi L Rev 1205, 1303-20 (1983); David S. Bogen, The Free Speech Metamorphosis of Mr. Justice Holmes, 11 Hofstra L Rev 97 (1982). 
tongues."51 How different this sounds from the earlier, dismissive talk of "privileges" that government may subject to such conditions it sees fit to impose. Just so, here is another paragraph from a similar Holmes dissent written near the end of the same decade, in 1928: "[I]f there is any principle of the Constitution that more imperatively calls for attachment than any other it is the principle of free thought-not free thought for those who agree with us but freedom for the thought that we hate." 52 There is obviously a stronger commitment to free speech in this passage than in Holmes' earlier, somewhat disdainful, remarks.

Here is Holmes again in his most famous dissent in 1919, in Abrams $v$. United States:

[T]he best test of truth is the power of [a] thought to get itself accepted in the competition of the market. . . That at any rate is the theory of our Constitution. It is an experiment, as all life is an experiment. . . . While that experiment is part of our system I think that we should be eternally vigilant against attempts to check the expression of opinions that we loathe and believe to be fraught with death, unless they so imminently threaten immediate interference with the lawful and pressing purposes of the law that an immediate check is required to save the country. I wholly disagree with the argument ... that the First Amendment left the common law as to seditious libel in force. ${ }^{53}$

And here is Holmes dissenting (still again with Brandeis) in 1925: "If in the long run the beliefs expressed in proletarian dictatorship are destined to be accepted by the dominant forces of the community, the only meaning of free speech is that they should be given their chance and have their way."54 One even reasonably attentive to Holmes will see something new in passages such as these. In significant ways they will eventually lend strong support to academic freedom as well. But, more generally, Holmes suggests that any idea (including one that would reorganize the government as a proletarian dictatorship and terminate the Constitution itself) is as fully protected as any other. The first amendment itself does not take sides.

Holmes now philosophically resigns himself to the obvious in a larger sense: life must settle for proxies of truth. Indeed, life can only provide proxies as truth, each in turn being perpetually subject to displacement by other ideas that become more compelling proxies of truth, each proxy simply being whatever seems most correct to each of us, tested in comparison with alternatives equally unrestricted in their availability to us-an availability it is one function of freedom of speech to assure. The notion of bad tendency as a justification to restrict the availability of an idea threatening the status of

51. Milwaukee Publishing Co. v Burleson, 255 US 407, 437 (1920) (Holmes dissenting). Compare Lamont v Postmaster General, 381 US 301 (1965). (Lamont is an important case that takes Holmes' suggestion seriously; it holds that an Act of Congress burdening certain political mail violates the first amendment, despite the plenary power vested in Congress. Incidentally, Lamont is worthy of special remembrance; it is the first case ever to strike down an Act of Congress on first amendment grounds. Id at 305.)

52. United States $v$ Schwimmer, 279 US 644, 654-55 (1928) (Holmes dissenting).

53. 250 US 616, 630 (1919) (Holmes dissenting). Surely Holmes' position has moved from his 1908 view that the first amendment did little more than enact the common law whole.

54. Gillow, 468 US at 673 (Holmes dissenting). 
institutions, groups, established wisdom, or values through speech cannot survive this view of the first amendment. The status quo must always defend itself. The notion of bad tendency as a justification to restrict the availability of an idea is gone.

Within this central vision of the first amendment, the bad tendency test gives way under the Holmes rationale. The matter is further explained sharply in a later dissenting opinion by Justice Rutledge in 1944:

It is axiomatic that a democratic state may not deny its citizens the right to criticize existing laws and to urge that they be changed. And yet, in order to succeed in an effort to legalize polygamy[, for example,] it is obviously necessary to convince a substantial number of people that such conduct is desirable. But conviction that the practice is desirable has a natural tendency to induce the practice itself. Thus, depending upon where the circular reasoning is started, the advocacy of polygamy may either be unlawful as inducing a violation of law, or be constitutionally protected as essential to the proper functioning of the democratic process. ${ }^{55}$

The net of it is, then, that the natural tendency of one's freedom to present what is currently thought hateful and wrong as actually quite desirable and right, to induce breaches of law by those to whom the appeal is communicated-some of whom may then break the law as it is-is not enough to enable the state to chill or to punish the person making the case. Under this very strong view, even predictable increases in violations of existing laws, traceable to the efficacy of the criticism of the law, cannot be expensed to the critic of the existing law or of the prevailing social ethic, even though the lawbreakers themselves may still be punished. It is a social cost of free speech in a democratic state.

In so suggesting, moreover, Justice Rutledge was but elaborating usefully on an abrupt point made eighteen years earlier, in Whitney $v$. California, by Brandeis (who joined Holmes in the various dissents quoted above): "The fact [alone] that speech is likely to result in some violence or in destruction of property is not enough to justify its suppression." 56 This, indeed, is very strong stuff. It is also, however, the meaning of free speech in the United States. From this point and this principle, all modern doctrines descend. It is, moreover, not necessary to review a lengthy series of subsequent cases to illustrate the principle. One case most especially, New York Times Co. $v$. Sullivan, ${ }^{57}$ decided by the Court in 1964, shows in a single decision how greatly results have changed.

Sullivan was an ordinary civil libel proceeding brought in the Alabama state courts. False statements referable to Mr. Sullivan as a city commissioner in Montgomery, Alabama, had appeared in a political advertisement published by the New York Times (the advertisement solicited funds for a political cause). The text of the advertisement contained factual exaggerations about Sullivan's actions as city commissioner and about the extent of his participation in certain civil rights confrontations in Montgomery. The

55. Musser v Litah, 333 US 95, $101-02$ (1948) (Rutledge dissenting) (citations omitted).

56. 274 US 357,378 (1926) (Brandeis concurring).

57. 376 US 254 (1964). 
statements were deemed defamatory per se under the Alabama common law of libel, consistent with the state judge's instructions, and the jury awarded $\$ 500,000$ in general damages in favor of Sullivan and against the Times.

Sullivan might have been reversed under the Supreme Court's thenexisting first amendment doctrine. ${ }^{58}$ But the Supreme Court by-passed alternative grounds for reversing the judgment and proceeded to rewrite libel law in the United States. Directing its attention to the centrality of free speech and political issues in the United States, the Supreme Court held that, up to a certain point, even false press reports that may damage the public standing of a public official may be immune from civil or criminal redress. Indeed, the Court went on to hold, neither factual falsehood, nor actual harm (loss of job, shunning by the community), nor even lack of reasonable care in ascertaining the actual facts prior to publication, nor all in combination will necessarily be sufficient for a successful libel action. The first amendment, the Court held, not only disallows criminal prosecution of the publisher, ${ }^{59}$ but also bars a law providing for personal, civil redress. To overcome that bar, according to the Court's opinion in Sullivan, the plaintiff must meet a new (first amendment) standard of scienter. Specifically, as determined in a later case, St. Amant $v$. Thompson, the plaintiff must establish by evidence of convincing clarity that the defendant actually knew the factual statements were false and published them despite that knowledge or, at a minimum, published them as true even though the defendant "in fact entertained serious doubts as to the[ir] truth. . . .60 Negligent failure to check for falsehood is not enough. Sullivan grants a first amendment immunity to standards journalists themselves would regard as professional malpractice. In this respect most especially, it is a remarkable case. Moreover, the first amendment rule Sullivan announced has since been extended to other figures who attract political interest and its implicit risks of parody and of withering, sometimes cruel, ridicule, as well as of defamation. ${ }^{61}$ Sullivan has cut a wide first amendment swath through the law of torts, particularly libel and defamation.

58. There were several grounds on which the Supreme Court might have reversed without announcing the rule it did. Specifically, for example, the amount awarded by the jury bore no relationship to any evidence of actual damage to Sullivan's public standing in Montgomery, nor was there evidence of mental anguish or community shunning (no such specific evidence was required in cases alleging libel per se). Moreover, Sullivan was not mentioned by name in the advertisement, nor did the Times itself do anything other than publish the advertisement, that is, it had no direct hand in the advertisement's original preparation, nor did it represent anything on its own behalf as a source of news. Any award beyond purely nominal damages under these circumstances might well have been regarded as foreclosed by the first amendment. No broader issue need have been reached.

59. The first amendment assuredly does apply to bar such prosecutions. See, for example, Garrison v Louisiana, 379 US 64 (1964).

60. St. Amant $v$ Thompson, 390 US 727, 731 (1968) (decided subsequent to Sullivan and adding to its reasoning).

61. For its most recent extension and application, see Hustler Magazine, Inc. v Falwell, 485 US 46 , 56 (1988) (political advertisement parody depicting televangelist fictitiously as a drunken and incestuous hypocrite, held absolutely protected by first amendment regardless of emotional distress publisher may have meant to cause and was determined in fact to have caused). Husller holds that the first amendment protects a right of political ridicule virtually absolutely. Hustler is also a highly important terminal case in a very long historical line; it ends the last possible vestige of any valid law of seditious libel in the United States. 
Underneath, however, Sullivan is of a first amendment piece with the Holmes-Brandeis-Rutledge quotations we have abstracted from cases going back to the 1920s. The overall lesson is that neither the bad tendency, nor the "clear and present danger," nor yet the actual fact of some proximately resulting harms-even harms foreseeable to the author, the parodist, or the speaker as of the moment he or she looses her words on paper or sends them out into some public or private audience-will necessarily bring the utterer athwart of the law. Whether it will do so depends on what one sees to be the resulting cost to free speech. In Musser, Justice Rutledge's insightful dissent explored this concept of cost in a general way through the compelling example of speech advocating polygamy. ${ }^{62}$ In Sullivan, the Court likewise pursued the concept of costs to free speech and developed still an additional step: "That erroneous statement is inevitable in free debate, and that it must be protected if the freedoms of expression are to have the 'breathing space' that they 'need ... to survive' [seems obvious]."63 Thus, in the Court's view, even factual misstatements, including some that may be quite damaging to public officials or to other public figures, nonetheless receive a qualified first amendment immunity. Without extending our case law examples much further, perhaps we can now see where these first amendment trends will lead.

In the 1950s, Judge Learned Hand proposed a first amendment formula that tried to catch some of the developments we have rather casually reviewed. His formulation is useful as a general statement, and far removed from the original, bad tendency test. Even so, it needs careful reading; it is often misunderstood. Here is the general formulation Hand suggested: "In each case [courts] must ask whether the gravity of the 'evil,' discounted by its improbability, justifies such invasion of free speech as is necessary to avoid the danger." 64

Judge Hand's formulation is usually read as though it were a simple tort law formula for judges to apply. It is taken to say that if (but only if) one has fairly discounted the gravity of the evil to be avoided by the improbability of its likely happening as a result of someone's speech, so as not to exaggerate the need for the restraint on speech and so as not needlessly to interfere with speech, one may then invade free speech, albeit only to the extent necessary to avoid the danger. ${ }^{65}$

62. See note $\mathbf{5 5}$ and accompanying text.

63. 376 US at 271-72 (citations omitted). Critics of Sullivan (and there are many) do not disagree with the basic statement. Rather, the quarrel is whether the scienter standard exceeds any proper first amendment need, that is, that at least with respect to commercial publishers including newspapers, liability for negligent failure to check for falsity would be the appropriate line for the first amendment to draw where the plaintiff carries his or her burden under every other standard provided in Sullivan itself.

64. Dennis ข United States, 341 US 494, 510 (1951), citing opinion of Judge Learned Hand in United States v Dennis, 183 F2d 201, 212 (2d Cir 1950).

65. Alternatively, implicit in the formula is the suggestion that where for some reason the measures taken to avoid the evil fail, but if the test is otherwise satisfied, the law may provide appropriate redress for the actual harm that ensued. 
However, this reading goes too fast and takes too much for granted. One must read Judge Hand's statement more carefully. Judge Hand was framing a larger, harder question, and he did not say what the answer would necessarily be: courts must additionally ask whether $X$ danger of $Y$ evil justifies such invasion of free speech as may, admittedly, be necessary to avoid the danger; there is no implicit assumption that it necessarily will.

Moreover, from what we have reviewed thus far, it should now be apparent that the answer to Judge Hand's unanswered question turns out to be quite complicated under first amendment doctrine today. The short answer is that sometimes it will, but sometimes it won't, as the Court's holding in the Sullivan case illustrates, as Rutledge's example in Musser implies, and as the Brandeis quotation in Whitney declares. The answer is it won't, if the invasion leaves freedom of speech "too little space in which to breathe"- too little space to enable people to speak passionately for their beliefs or to seek through their speech to transfigure society, regardless of the direction they would try to take it by the political effects of their ideas and their appeals. In the hard law of the first amendment, the central meaning of first amendment in the United States today is found in the far greater substantiality of this constitutionally sheltered "breathing space" than was once provided. In the decades since 1907-1908 and Patterson, 66 constitutional doctrine has moved very far (farther than most Americans themselves understand) from the bad tendency test.

\section{E}

As an interlude to our discussion thus far, now that we have a more current and different grasp of freedom of speech under the first and fourteenth amendments, ${ }^{67}$ we can easily see how freedom of speech fits some fairly standard cases of the sort we already touched upon. We are now in a much better position than we were a few pages ago to examine how such cases might come out on the merits when reviewed in the Supreme Court since these changes occurred.

An excellent case for such an examination is Pickering $v$. Board of Education, ${ }^{68}$ our earlier case involving Marvin Pickering, the letter-writing high school teacher, which was decided in the Supreme Court just four years after New York Times $v$. Sullivan. Pickering's difficulties, one will recall, arose from the critical letter he wrote to a local newspaper, commenting on recent school bond measures that had failed despite strong and well-publicized school board endorsement and support.

Pickering's letter identified him as a local teacher, although he declared in the letter-albeit complainingly - that he was writing only "as a citizen, taxpayer and voter, and not as a teacher, since that freedom has been taken

66. See note 10 and accompanying text.

67. Bearing in mind that, since 1925 the first and 14 th amendments have been treated alike in respect to free speech.

68. 391 US 563; see note 44 and accompanying text. 
away from the teachers by the administration." 69 His letter harshly criticized the board's public representations made to encourage voter support for the bond issues; it suggested that some of them were untrue or at least misleading. His letter also argued that some past uses of funds were not in keeping with their original representation, for example, that more had been spent for athletics than for education, contrary to what had been said by the board. Overall, moreover, his letter laid a large portion of blame for the failure of the bond issues on the board and the school administration itself. Some specific statements in his letter (for example, on the cost of school cafeteria lunches) were false, although there was no suggestion that Pickering either knew or thought them to be inaccurate.

Previously, we limited our review of Pickering to a single, preliminary point, namely, a New Bedford-type claim made by the board in the state court that so long as Pickering continued to work as a public employee with notice that he did so under the constraint of forbearing from criticizing the schools, he could not complain of being terminated once he was shown in a fair hearing to have dishonored that condition. Under this view, recall, it was up to Pickering to determine the acceptability of the tradeoff; he could quit whenever he found it unacceptable, but he could not ignore it and expect to be kept on. We already noted the Court's rejection of that proposition under the Frost rationale. But we also noted something else: that the doctrine of unconstitutional conditions is often inconclusive of real cases; it begs the question of whether some conditions are not necessarily unconstitutional at all. Thus, a concrete example-regarding access to classified informationwas furnished in a passing footnote to make the point plain. ${ }^{70}$ Noting this inconclusiveness, we returned to the main track of first amendment doctrine. We return, re-examining Pickering, to see the final result reached under substantive first amendment law.

Pickering's letter identified him as a teacher. Moreover, he wrote about matters affecting the public schools about which readers might assume he was particularly well informed. In places, his letter was factually inaccurate. It was also sarcastic, insinuating, and rude. It was not addressed quietly or internally to make helpful or constructive suggestions to the elected members of the board. Rather, it was released into the local newspaper for its general ventilative effect. To be sure, there was no evidence of its community impact.

69. Pickering, 391 US at 578. Pickering's complete letter appears in the Appendix of the case, id at 575. As to his latter statement, the Supreme Court concluded that he had some factual basis for it to the extent that the Teachers Handbook required prior submission to a school principal and triplicate copies to a publicity coordinator in advance. Since the letter elsewhere indicated that this was the basis for Pickering's claim (that "freedom has been taken from the teachers by the administration"), the Court held that readers were merely invited to judge for themselves, that is to say, that the statement was clearly offered as Pickering's opinion, rather than as a revelation of false facts. Id at 570-71.

70. See note 49 (Access to highly classified information may be denied on considerations of national security, and even one's political affiliations that cannot be forbidden may nonetheless be taken into account in granting or withholding such access in certain circumstances, depending upon the degree of perceived serious risk.). 
Nonetheless, were there no suitable grounds for the board to expect something better of a teacher in Marvin Pickering's position? In Pickering, the Court first held-as we might expect-that a rule forbidding any teacher or other school employee to comment publicly on any matter affecting the local schools without administrative permission would be an unconstitutional prior restraint under the first amendment. Assisted now by Sullivan and our review in the preceding section, we can now go much further, however, and see how the result for Pickering was substantially more favorable than when weaker views of the first amendment prevailed. Specifically, here is how matters went.

The opening emphasis of the opinion is on the public subject matter of Pickering's letter: school taxes, referendum bond measures, and popular voting at scheduled elections, the stuff of the democratic process itself. ${ }^{71}$ Such public political speech, the Court insists, is highly protected overall; one cannot, as a condition of being a teacher, be forbidden to address such public issues publicly on the claim that school interests would be better served by a nonpartisan silence. Moreover, the critical, rather than neutral or supportive, tone of Pickering's views is "unequivocally reject[ed]" as providing grounds for his dismissal; 72 the first amendment does not allow the school board to require that he speak only favorably or neutrally, whether of itself or the alleged need for school bonds, as a condition of speaking at all.

Next, that Pickering was not merely critical in what he wrote but was also unpleasantly insinuating toward the board was treated by the Court as insufficient grounds to fire him for his public or professional incivility. "In these circumstances," Justice Marshall said, "we conclude that the interest of the school administration in limiting teachers' opportunities to contribute to public debate is not significantly greater than its interest in limiting a similar contribution by any member of the general public." 73 Thus the board could not seize upon Pickering out of frustration that, in their view, his letter did not represent them fairly or treat them courteously, though their feeling might itself be an understandable and even warranted reaction in light of the letter's tone. The board's interest in requiring general fairness, or even civility, was

71. Pickering, 391 US at 564-68. In contrast, a subsequent case, Connick v Myers, 461 US 138 (1983), draws a bright-line distinction that puts public employees at risk for voicing internal workrelated grievances principally related to their own status. Under Connick, the employee may be fired, without recourse at all under the first amendment, by those of whom or to whom they complain. The Court's desire to seek some de minimis limit on "mere internal complaint" cases (as it is inclined to call them) is understandable, but the line drawn by Connick is not. The difficulty with Connick is that its first amendment line is arbitrary and indifferent to any particularized facts as well as to the severity of the restriction at risk (dismissal). Connick's lesson is that public employees who may have a just complaint may be fired with impunity by the very person already abusing them simply for speaking about the matter, even assuming their complaint is entirely true. Indeed, they may be fired because it is true. In respect to academic personnel, moreover, since it is obvious that both general and specific "workplace conditions" are constitutive elements of getting work done in a literal sense, academic freedom itself implies the protection of some prerogative to speak about such matters. See, for example, Matthew W. Finkin, Intramural Speech, Academic Freedom, and the First Amendment, 66 Tex L Rev 1323, 1335-45 (1988).

72. Pickering, 391 US at 570 .

73. Id at $\mathbf{5 7 3}$. 
too insubstantial under the circumstances (that is, as the court noted, "not significantly greater than its interest in limiting a similar contribution by any member of the general public") ${ }^{74}$ The connection between the letter and Pickering's possible professionalism or lack thereof as a teacher (how he conducted himself in the classroom) was wholly speculative. The Court likewise noted that Pickering did not personally work for the board itself. ${ }^{75}$

Finally, the Supreme Court protected Pickering despite his factual mistakes, pursuant to the Sullivan rationale. As in Sullivan, the Court noted some margin of error is inevitable in such matters. The Court held that to cite Pickering's mistakes as creating the risk of dismissal when venturing into local, public, political debate would provide too little breathing space under the first amendment. The board could seek correction of the factual mistakes by recourse to the newspaper columns Pickering used. It could not, however, dismiss Pickering. In short, Pickering's free speech claim prevailed.

Pickering is thus an excellent illustration of how things have changed since 1908 , and of how much stronger the first amendment has become in a general way. It is now but a very short step to fit academic freedom within the first amendment. We turn at once to see how it was done.

\section{$\mathbf{F}$}

Academic freedom made its first express Supreme Court appearance in a dissent by Justice William Douglas, a former academic, in a 1952 case, Adler $v$. Board of Education. ${ }^{76}$ With Justice Black concurring in his dissent, Douglas invoked "academic freedom" three times, in a specific, first amendment usage. He also gave the phrase a distinguishing identity for general legal use.

At issue in Adler was a New York statute providing for the disqualification and removal from public employment of any person espousing the use of violence to alter the form of government in the United States. The act (the Feinberg Law $^{77}$ ) also provided that membership in any listed subversive group would constitute prima facie evidence that the person possessed the disabling trait. It further provided for disclaimer oaths and other detailed inquiries, as well as investigative hearings.

The majority of the Court sustained the statute from facial attack. In the main, it relied on the still-lingering right-privilege distinction, harkening all the way back to 1892; for that reason, the majority position was not to last. Fifteen years later, the right-privilege rationale no longer sufficed as a prop in the Supreme Court, and Adler was substantially overruled. ${ }^{78}$ Our interest is, correspondingly, limited to the Douglas dissent.

74. Id.

75. So the result might have been different had Pickering been an employee of the Board. Later cases press this point rather hard.

76. Adler $v$ Board of Educ. of the City of New York, 342 US 485, 508 (1952) (Douglas dissenting).

77. 1949 Laws of State of New York ch 360.

78. See Keyishian v Board of Regents, 385 US 589, 605-06 (1967), discussed at notes 107-08 and accompanying text. ("[C]onstitutional doctrine which has emerged since [Adler] has rejected its major premise. That premise was that public employment, including academic employment, may be 
Justice Douglas voted to hold the Feinberg law unconstitutional. His overall approach was of a piece with Meyer and Bartels, two cases we have previously reviewed. ${ }^{79}$ In Adler, however, Douglas expressly drew on the first amendment to shelter academic freedom. In Meyer, as we noted, the protection of academic freedom was merely an incident of substantive due process review. The analytic similarities of the cases-the majority opinion in Meyer and the Douglas dissent in Adler-are nonetheless striking.

In Meyer, the Court found fault, not with the stated object sought by legislature (to assure English literacy in youngsters regardless of the school in which they were enrolled), but with the means. Similarly, Justice Douglas did not find fault with the stated object of the Feinberg Law. ${ }^{80}$ Rather, he argued, the fault also lay with the means. In Meyer, the objection was that the device used by the legislature to achieve a proper end was unconstitutionally excessive. A similar objection, in Douglas's view, was equally applicable in Adler.

Douglas wrote that if the state did not mean to "raise havoc with academic freedom," 81 it must confine itself to limiting certain specific acts endangering public safety or putting public education at unfair risk. But the Feinberg Law, he insisted, was not so confined and was, rather, prejudicially restrictive in respect to those it disabled from teaching and excessive in how it would necessarily affect others as well. Declaring that " $[t]$ here can be no real academic freedom in [the] environment" of exclusion and of teacher fear generated by the Feinberg Law, 82 Douglas found fault with it in two intertwined respects. The first was that the per se employment disqualification of persons from academic appointment in any public school based on what they might espouse as individuals was inconsistent with one of the concerns of academic freedom because it eliminated a nonrandom,

conditioned upon the surrender of constitutional rights which could not be abridged by direct governmental action. . . . TThat theory was expressly rejected in a series of decisions following Adler." (citations omitted and emphasis added)).

79. Meyer, 262 US 390; Bartels, 262 US 404; see notes 24-34 and accompanying text.

80. The "stated object" is deliberately emphasized because, given the broad manner in which the statutes in Meyer and Adler were drawn, the question of what the legislature in each case actually meant to do is unclear. In Meyer, as discussed in note 30, there was reason to believe the legislature may have been acting only partly in good faith, that is to say, to improve English literacy but also to suppress the German language. The statute was efficiently drawn to do both. In Adler, there is the same double effect (improve national security but also suppress Communists) and possibly some of the same mixed legislative motives as well (in Adler, as in Meyer, the statute seems drawn to do both). So the problem in each case, commonplace in civil liberties litigation, is in large part this problem of double effects and the corresponding problem of how best for the judiciary to confine legislatures to legislate appropriately, limiting their legislation only to constitutionally permissible ends. The majority in Meyer and Douglas in Adler confronted this problem directly. But neither Holmes in Meyer nor the majority in Adler did. The general judicial approach since Adler is to subject statutes affecting first amendment rights to strict scrutiny, with no favoring assumption to the legislature that the breadth of the statute was required by the circumstances; rather, the necessity for such breadth must itself be shown to the satisfaction of the court. (For an oft-cited reference on the general role of judicial review and heightened scrutiny in first amendment cases, see United States $v$ Carolene Products Co., 304 US 144, 152 n4 (1938)).

81. Adler, 342 US at 509 (emphasis added).

82. Id at 510 (emphasis added). 
ideologically specific cohort from further consideration as teachers in any public school. ${ }^{83}$ So sweeping an exclusion, in Douglas's view, raised a serious academic freedom, first amendment concern. ${ }^{84}$ Additionally, the statute also operated as a source of intimidation to other teachers. "[The] system of spying and surveillance [provided for by the statute] with its accompanying reports and trials cannot go hand in hand with academic freedom," Douglas argued, taking into account the full apparatus of the Feinberg Law. ${ }^{85}$ "It produces standardized thought, not the pursuit of truth." 86 The problem of the Feinberg Law in this view was that it bore down threateningly on all teachers in the New York system. It would, in Douglas's view, compel teachers within the system to steer a wide course to keep from triggering the trip wires of the New York law. It was far different than a statute directed to acts of professional misconduct. Its chilling effect, lest one draw attention to oneself (for example, by the nature of the subject, the materials one might assign, or how one might propose to examine the subject in class), was obvious and substantial, in Douglas's view. ${ }^{87}$ A more narrowly crafted law was required to avoid the costs to academic freedom.

The Douglas dissent in Adler is notable beyond the fact that the phrase "academic freedom" appears for the first time in direct first amendment usage. Douglas also employed academic freedom as a distinct, identified subset of constitutional first amendment concern. He does not dismiss it as merely parasitic on a standard free speech claim. Within the framework Douglas provides, moreover, there remain almost no problems left to give it recognizable shape within standard first amendment law.

G

Later in the same term, Justice Felix Frankfurter (like Douglas, also a former academic) provided a concurring opinion that nearly completes the identification of academic freedom protection as a subset of first amendment

83. Id at 508-09.

84. The concern is that the exclusion self-selects all of a certain incidental political disposition just as, say, a Soviet exclusion of all individuals holding pro-capitalist attitudes from teaching eligibility would do, within their system, in an opposite way. This is an academic wrong, moreover, in that it is not merely an alternative way of framing a standard, personal free speech claim.

85. Adler, 342 US at 510-11 (emphasis added).

86. Id at 511 .

87. This may, incidentally, be a suitable place to note the connection of the 1940 Statement of Principles on Academic Freedom and Tenure (emphasis added) with Justice Douglas's position in Adler. Teachers perpetually subject to nonrenewal, by mere notice that their services are no longer required by the institution, may be kept on their toes by the uncertainty of reappointment from year to year. But the lack of tenure also undercuts academic freedom in a serious way; as did the law in Adler, albeit in a different fashion, the system presses teachers to steer away from any possible trip wire that might put them out on the street. Thus, the AAUP regards tenure, following a probationary period (up to seven years), with dismissal thereafter for cause as determined in some kind of pretermination academic due process hearing, a vital safeguard to academic freedom itself. (The alternative, in a manner of speaking, is a system that keeps those who teach on their knees.) See William R. Keast, Faculty Tenure (Jossey-Bass, 1973); Fritz Machlup, In Defense of Academic Tenure, 50 AAUP Bull 112 (1964); William W. Van Alstyne, Tenure: A Summary, Explanation, and "Defense," 57 AAUP Bull 328 (1971); Ralph S. Brown \& Jordan E. Kurland, Academic Tenure and Academic Freedom, 53 L \& Contemporary Problems 325 (Summer 1990). 
law. In Wieman v. Updegraff,, 88 the Supreme Court reviewed a state statute requiring compliance with a broad disclaimer oath as a condition of public employment. ${ }^{89}$ Frankfurter concurred in the decision holding the statute unconstitutional under the fourteenth amendment, but he wrote separately to say why the statute was invalid as applied to teachers in particular, apart from its unconstitutional effect on the associational rights of other public employees.

The statute applied to all persons seeking or holding public jobs. The particular case before the Supreme Court, however, had been brought on appeal by several state college faculty members. Justice Frankfurter held that the oath requirement was too broad to be sustained as to them in particular. His opinion, with Douglas concurring, marked out tightened boundaries limiting state control of public school and university faculty, on a specialized rationale. Frankfurter's objections in Wieman were based on vintage academic freedom premises, absorbed into first and fourteenth amendment law.

Closely tracking Douglas's opinion in Adler, Frankfurter used the same constitutional analysis to the state law at issue that Douglas had applied to the Feinberg Law. Here, as in Adler, the first objection was to the winnowing effect of the disclaimer oath on the pool of eligible appointees for public school or state university teaching. The oath's exclusion was a coarse means of checking legitimate public interests in determining professional competence or on-the-job integrity. At the same time, it was bound to have a parochializing effect downstream, shaping the scope of academic freedom as a practical matter. Related, but equally substantial, in Frankfurter's view, was the additional dampening effect of the oath on the remaining (already narrowed) field of academic personnel. The point is the same as the one Douglas emphasized in Adler: the intimidating effect of the regulation on all remaining academic personnel. Both branches of Frankfurter's objection are quickly noted in the following few words:

$[\mathrm{T}]$ he Fourteenth Amendment protects all persons, no matter what their calling. But, in view of the nature of the teacher's relation to the effective exercise of the rights which are safeguarded by the Bill of Rights and by the Fourteenth Amendment, inhibition of freedom of thought, and of action upon thought, in the case of teachers brings the safeguards of those amendments vividly into operation. Such unwarranted inhibition upon the free spirit of teachers affects not only those who, like the appellants, are immediately before the Court. It has an unmistakable tendency to chill that free play of the spirit which all teachers ought especially to cultivate and practice. ${ }^{90}$

Significantly, Frankfurter added an observation that warrants close attention: "The functions of educational institutions in our national life and the conditions under which alone they can adequately perform them are at the

88. 344 US 183 (1952).

89. The oath eliminated from any public employment any person affiliated with any listed subversive organization, whether or not the disqualified person was aware of whatever it was that made the organization subversive when he or she joined. The "[i]ndiscriminate classification of innocent with knowing activity," the Court held, cut too wide and arbitrary a swath. On that ground it was held invalid under the due process clause of the 14th amendment. Id at 191.

90. Id at 195 (emphasis added) (Frankfurter concurring). 
basis of these limitations upon State and National power."'91 What are "these" limitations? Obviously, they are those that he had just addressed: first and fourteenth amendment limitations on state and national power to narrow the width of academic eligibility or chill the professionalism of public school or public university faculty in performing their proper work.

What underlies these limitations? "The functions of educational institutions ... and the conditions under which alone [academic personnel] can adequately perform them," Frankfurter insisted.92 What functions? "The" functions include critical educational teaching functions, as Frankfurter understood those functions, of course.

Frankfurter's operating premises all sound very familiar by 1952 , the date of his opinion, in terms of the general case already long since made outside the Constitution (till now), to explain the imperatives of academic freedom. But in Wieman, Frankfurter concretely linked that case finally into the hard law of the first and fourteenth amendments as well. He soundly located in these amendments a strong set of constitutional restrictions on state and on national power in establishing and operating public educational institutions. Frankfurter's position in Wieman was no different with respect to public educational institutions than the Holmes dictum in the 1920s and Holmes's discussion of the post office. ${ }^{93}$ The government may give up the post office whenever it likes, Holmes had said, but may not presume to run it however it pleases, because, while the post operates, its use by each of us on fair first amendment terms is virtually as critical as the free use of our tongues. So, equally, Frankfurter suggested in Wieman, the government may give up public education whenever it likes, yet not conduct it other than according to conditions of academic freedom so long as it stays in the business of education. The premises of the first amendment require the protection of academic freedom in the structuring of state universities and public schools.

Five years later, Frankfurter reiterated and filled out these thoughts in Sweezy v. New Hampshire, decided by the Supreme Court in 1957.94 Sweezy arose out of investigative hearings conducted by the New Hampshire Attorney General pursuant to state legislative directives under the New Hampshire Subversive Activities Act. ${ }^{95}$ It is of a piece with Adler, Wieman, and a dozen other cases pulling and hauling at the first amendment during the 1950s when disloyalty investigations, oath requirements, and new employment restrictions loomed large.

New Hampshire Attorney General Louis Wyman had subpoenaed Paul Sweezy to answer questions including several inquiring into specific lectures he had given at the University of New Hampshire. At the hearings, Sweezy freely described himself as a "classical Marxist" and a socialist; he also

91. Id at 197 (emphasis added).

92. Id.

93. Burleson, 255 US at 437; see notes 51-54 and accompanying text.

94. 354 US 234 (1957).

95. NH Laws 1951 ch 193; now NH Rev Stat Ann, 1955, ch 588, §§ 1-16 
testified that he had never advocated the use of violence as a means of altering any government in the United States. However, Sweezy declined to divulge what he had discussed in his lectures at the university. He was cited for contempt and jailed until he would comply.

The majority opinion of the Supreme Court in Sweezy is only of passing interest, because it ultimately turned on a rather narrow ground. The Court noted that the questions asked of Sweezy skated very close to first amendment concerns of free speech and academic freedom (Chief Justice Warren's observations were strongly supportive of both kinds of first amendment claim). ${ }^{96}$ Then, however, the opinion moved away from that discussion to hold that there was insufficient evidence in the record to sustain the claim that the legislature wished the Attorney General to pursue its inquiry in the manner he had pressed against Sweezy. That being the case, the Court held, Sweezy's refusal to answer was not clearly in contempt of anything the legislature might have sought, so treating Sweezy as in contempt was a denial of due process of law. Justice Frankfurter (with Justice Harlan joining him) concurred in the result, but not in Chief Justice Warren's reasoning. Frankfurter's position required that the case turn on the substantive academic freedom first amendment claim Sweezy had advanced. Finding the state attorney general authorized by the state legislature to have proceeded as he did, Frankfurter went directly to the sole remaining question: did the first amendment shield Sweezy's refusal to answer questions probing the contents of his university lecture? Frankfurter and Harlan held, on first amendment academic freedom grounds, that it did.

The Frankfurter opinion extended his opinion in Wieman on academic freedom. In several respects it also anticipated the Sullivan holding about first amendment imperatives of adequate "breathing space." His point in Sweezy was not that teachers may never be required to account for their teaching; it was that the social imperatives of academic freedom operate through the first amendment to require close judicial superintendence of such inquiries because of their implicitly chilling effects. Thus, he held, only compelling need will excuse such an inquiry when it is pursued by political agencies, even including authorized committees of the state legislature and even when the university is one the state operates and funds.

The test Frankfurter proposed (and which he held had not been met in this case) was as follows: "Political power must abstain from intrusion into this

96. Chief Justice Warren's opinion did expressly invoke "academic freedom," and he distinguished it from general first amendment rights of political expression. "We believe that there unquestionably was an invasion of petitioner's liberties in the areas of academic freedom and political expression ...." Sweezy, 354 US at 250 (emphasis added). He also declared that "[t]he essentiality of freedom in the community of American universities is almost self-evident," and that academic freedom has a student, as well as a faculty, aspect: "Teachers and students must always remain free to inquire, to study and to evaluate, to gain new maturity and understanding; otherwise our civilization will stagnate and die." Id. Then, declaring that "[w]e do not now conceive of any circumstance wherein a state interest would justify infringement of rights in these fields," Warren nonetheless abruptly broke off the discussion ("[b]ut we do not need to reach such fundamental questions of state power to decide this case") and moved to another basis to decide. Id at 251. 
activity of freedom, pursued in the interest of wise government and the people's well-being, except for reasons that are exigent and obviously compelling."97 The phrase, "except for reasons that are exigent and obviously compelling," is not the usual standard an inquiring legislative committee need meet under the first amendment in order to overcome a first amendment-based refusal by a witness properly subpoenaed to respond to its questions. ${ }^{98}$ Frankfurter's standard is significantly more stringent, as he was at pains to acknowledge. His justification was a continuation of his concurrence in Wieman. It was directed to the social functions of universities and to the first amendment corollary of academic freedom that Frankfurter regarded as constraining the government when academic freedom is at stake:

When weighed against the grave harm resulting from governmental intrusion into the intellectual life of a university, such justification [as might ordinarily suffice in other settings] for compelling a witness to discuss the contents of his lecture appears grossly inadequate. ... These pages need not be burdened with proof, based on the testimony of a cloud of impressive witnesses, of the dependence of a free society on free universities. This means the exclusion of governmental intervention in the intellectual life of a university. It matters little whether such intervention occurs avowedly or through action that inevitably tends to check the ardor and fearlessness of scholars. ${ }^{99}$

Quoting at the end of his opinion from what, in 1957, he rightly called "perhaps the most poignant"100 statement on academic freedom yet to appear anywhere-a searing Statement of Remonstrance by The Open Universities in South Africa against their own government's actionsFrankfurter added the following:

A university ceases to be true to its own nature if it becomes the tool of Church or State or any sectional interest. A university is characterized by the spirit of free inquiry, its ideal being the ideal of Socrates-to follow the argument where it leads. . . It is the business of a university to provide that atmosphere which is most conducive to speculation, experiment and creation. It is an atmosphere in which there prevail the four essential freedoms of a university - to determine for itself on academic grounds who may teach, what may be taught, how it shall be taught, and who may be admitted to study. ${ }^{101}$

Returning to the case at hand, Frankfurter acknowledged that the particular intrusions posed by the limited questions Sweezy had been asked might seem minor and unthreatening, but insisted they were not. The overall chilling effect in the circumstances would be major, even if immeasurable. The justification given for the intrusions was neither exigent nor compelling under the circumstances. So, he held, considerations of first amendment academic freedom precluded Sweezy from being held in contempt. With Justice

97. Id at 262 (emphasis added).

98. Compare Sweezy with Braden v United States, 365 US 431 (1961) and with Wilkinson v United States, 365 US 399 (1961) (contempt convictions for refusing to answer legislative investigative committee questions upheld against first amendment objections, the standard of judicial review as applied not being as stringent as that required in Sweezy).

99. Sweezy, 354 US at 262.

100. Id.

101. Id at 262, 263, quoting The Open Universities in South Africa 10-12 (a statement of a conference of senior scholars from the University of Cape Town and the University of Witwatersrand). 
Harlan, he joined in the reversal of Sweezy's contempt conviction specifically on this ground.

In the dicta of the Chief Justice in Sweezy, and more concretely in the passages we have reviewed in Sweezy, Wieman, and Adler, distinct principles of academic freedom were linked directly to the protections of the first and fourteenth amendments. In academic life, the first amendment had come around.

\section{III}

Elaborating the Usages of "ACademic Freedom" in the SUPREME CourT

\section{A. (1957-1967)}

Within the decade following Sweezy, 1957-1967, a half-dozen decisions in the Supreme Court worked at the edges of the Adler, Wieman, and Sweezy doctrines expressly relating first amendment developments and academic freedom. Five of these cases principally involved public colleges and universities. The sixth touched public schools as well. The trend of the cases yielded a strengthened first amendment philosophy within the Court. Four of the six cases elaborated on academic freedom within the special protection of the first amendment. Only the first of these cases, Barenblatt v. United States, ${ }^{102}$ briefly faltered from Frankfurter's strongly stated position in Sweezy, although another also substantially bypassed a generalized academic freedom claim even while providing relief on an alternative ground. The other four moved strongly to verify claims of academic freedom marked out in first amendment metes and bounds.

Barenblatt $v$. United States, the first of these cases, was decided by a closely divided Court, five-to-four, in 1959. In Barenblatt, Justice Harlan wrote for a bare majority in sustaining a federal misdemeanor conviction of a former University of Michigan teaching fellow who had been prosecuted for contempt in refusing to answer questions during a public session of the House Committee on Un-American Activities. Several of the questions were directed to his possible knowledge of alleged Communist Party activities at educational institutions, including some seeking to determine the extent of his participation, if any, in Communist Party activities. Unlike Sweezy, none of the questions pressed him on any particular teaching or studying in which he may have been engaged, and the issue of academic freedom appears hardly to have been engaged.

Justice Harlan, finding the committee duly authorized to investigate the general subject, and finding also that the committee had reason to think the witness might have information pertinent to the inquiry, sustained the demand for answers against Barenblatt's first amendment objection. The

102. 360 US 109 (1959) 
majority opinion made no reference to academic freedom except as a footnote mention from an amicus brief filed by the AAUP. ${ }^{103}$

The dissent by Justice Black also yielded no useful focused discussion of academic freedom. Rather, the Black dissent launched an excoriating first amendment attack on the House committee generally. The case was adjudicated in generalized free speech terms. ${ }^{104}$ Barenblatt proved to be quite uneventful in the long run, either to extend Frankfurter's discussion in Sweezy or to cut it off.

Four years later, in Yellin $v$. United States, ${ }^{105}$ a similar contempt conviction of a witness who had declined to respond to questions-some of which bore on the witness's activities while at the University of Michigan-was overturned in the Supreme Court. Even so, the new five-to-four majority on the Court, though it held oppositely from Barenblatt, also deflected any academic freedom issue even more completely than the Barenblatt Court had done. The case overall is probably a better example of the Court still struggling to find its feet. The sole mention of "academic freedom" reported in the case went largely unaddressed. The case was disposed of in the noncomplying witness's favor, but on narrow procedural due process grounds. ${ }^{106}$

In contrast, in 1967, the New York Feinberg Law (previously upheld in the Adler case) was struck down on its face on substantive first amendment grounds in Keyishian v. Board of Regents. ${ }^{107}$ Moreover, the emphasis was not only once again centered on the first amendment; but the outcome also turned specifically on the professional effects of the law, that is, on its effects on teachers. The state law's requirement of an annual subversive-action

103. Id at $130 \mathrm{n} 29$. The AAUP amicus brief (October Term, 1958, No 35) argued that first amendment imperatives of academic freedom do not privilege teachers from accounting for their work, but suggested that the standards endorsed by Justice Frankfurter in the Sweezy case had not been fulfilled by the Committee, thus, that the contempt sanction ought not be sustained. Justice Harlan did not appear to dispute the point as established in Sweezy (he had, after all, joined Frankfurter's opinion in Sweezy); rather, his opinion implies that the issue was not necessarily engaged by the facts before the Court.

104. That is, the dissent, like the majority opinion, was occupied with the role of the House Committee on Un-American Activities overall and its broad threat to lawful dissent and political affiliation generally, rather than with the particular facts of the Barenblatt case. Justice Black did cite Sweezy, id at 139-40, as requiring proof of a compelling need before the committee could brush over a witness's first amendment interests; and he did conclude that no sufficiently compelling need had been established by the committee, but it was a secondary reproach at best. For a fresh view of Barenblatt generally, see Harry Kalven, $A$ Worthy Tradition 497-531 (Harper \& Row, lst ed 1988).

105. 374 US 109 (1963).

106. Id at 124. In Yellin, the witness was asked a number of questions in public session concerning his activities as a student at the University of Michigan and why he had provided no reference to having been at the University when he later applied for a steel-mill job. In declining to answer this and several other questions, Yellin read a statement in which he claimed privilege partly on grounds of academic freedom, id at 140 , but the objection is neither elaborated on nor further addressed by the Court. Rather, the majority of the Court held that Yellin could not be held in contempt for refusing to answer questions in any public session because a request that he had submitted to be heard solely in executive session had not been referred to the whole committee for consideration and voted on as provided by the committee's own rules. In short, the Court held that such procedural protections of witnesses, such as the Committee Rules, could not be ignored by the committee, even assuming the rules could be repealed or revoked at will.

107. 385 US $589,609,610$ (discussed in note 78 ). 
disclaimer affidavit, the scope of the required affidavit, and the heavy accompaniment of enforcement machinery laid in place for proceeding against those accused of taking the oath falsely, were held to be unconstitutional as applied to state university or public school teachers.

The analysis of the first amendment academic freedom abridgments of the Feinberg Law was undertaken by Justice Brennan in Keyishian. Overall, the analysis is of a piece with that of Justice Douglas in Adler, except that now it represented a majority position in applying the first amendment. Writing for a new majority, moreover, Justice Brennan placed the protection of academic freedom within the core of first amendment concerns and not at its margins. The paragraph in which he did so would be quoted repeatedly by the Court during the next twenty years:

\begin{abstract}
[A]cademic freedom . . . is of transcendent value to all of us and not merely to the teachers concerned. That freedom is therefore a special concern of the First Amendment, which does not tolerate laws that cast a pall of orthodoxy over the classroom. . . . The classroom is peculiarly the marketplace of ideas. The Nation's future depends upon leaders trained through wide exposure to that robust exchange of ideas which discovers truth out of a multitude of tongues, [rather] than through any kind of authoritative selection. ${ }^{108}$
\end{abstract}

In holding the law invalid as applied to those in public education, Keyishian marks an important rite of passage. What New York Times $v$. Sullivan had meant in respect to journalism in the United States-a landmark first amendment decision providing professional breathing room for critical journalism-Keyishian forcefully represents in respect to academic freedom, including the academic freedom of those holding appointment by the state.

Later in the same term in Whitehill $v$. Elkins, ${ }^{109}$ the Court voided a Maryland disclaimer oath on similar grounds. The Maryland act required teachers to swear as a condition of public university appointment that the oath taker was not engaged "in one way or another" (sic) in acts seeking the overthrow of the state or national government by force or violence. " 10 False swearing was made punishable as perjury. The opinion for the Court holding the requirement void was by Justice Douglas. He concluded that the oath act (and a section providing for the dismissal of those found on reasonable grounds to be subversive ${ }^{11}$ ) was too broad to be consistent with the first amendment obligations to secure adequate protection of academic freedom in public education.

108. Id at 603 (citations and quotation marks omitted, emphasis added). For examples of the steering effect of the Feinberg Law the Court found to conflict with academic freedom, see id at 601 ("The very intricacy of the plan and the uncertainty as to the scope of its proscriptions make it a highly efficient in terrorem mechanism. It would be a bold teacher who would not stay as far as possible from utterances or acts which might jeopardize his living by enmeshing him in this intricate machinery."). The opinion also draws heavily from Frankfurter's concurring opinions in Wieman, 344 US at 194-98, and Sweezy, 354 US at 255-67, in explaining the full first amendment rationale.

109. 389 US 54 (1967).

110. Maryland Subversive Activities Act, Art 85A Md Code Ann $\S \S 1,11,13$ (Michie 1969), repealed by Acts 1978, ch 257.

111. Id at $\$ 14$. 
As in Keyishian, Sweezy, Wieman, and Adler, moreover, Douglas's first amendment analysis focused on the law's impact on teachers and professors. ${ }^{112}$ As an example of the law's objectionable steering effect, Douglas observed that a faculty member, once having taken the oath, would need to avoid attending any international conference whose auspices were not totally known to him, simply from fear of drawing an investigation upon himself as having violated his oath. ${ }^{113}$ After quoting extensively from Sweezy, Douglas framed the dispositive objection this way:

The continuing surveillance which this type of law places on teachers is hostile to academic freedom. . . . The restraints on conscientious teachers are obvious. . . That very threat [posed by the breadth of the disclaimer oath] may deter the flowering of academic freedom as much as successive suits for perjury. ${ }^{114}$

And, finding the breadth of the disability unwarranted because any proper governmental concerns with security or with professional integrity could be composed by more narrowly drawn rules not imposing these in terrorem effects on academic freedom, the Court held the Maryland statutes void.

In Whitehill, Douglas thus employed the reference to academic freedom as a reference to an understood, settled first amendment shield against the state in its superintendence and control of public education, much in keeping with his views dating from Adler, as well as in keeping with Justice Brennan's Keyishian opinion in the same term of the Court. The proper fit, identifying academic freedom with the first amendment, was made. The measured protection of academic freedom from hostile state action had become a settled feature of first amendment law.

Intermediately during this decade (1957-1967), moreover, two other cases were resolved by the Supreme Court in which "academic freedom" appears, although less centrally than in either Keyishian or Elkins. Both cases also resulted in holding state statutes invalid on first and fourteenth amendment grounds. The more relevant of the two cases, Baggett $v$. Bullitt, decided in $1964,{ }^{15}$ had been brought by sixty-four members of the faculty, staff, and student body at the University of Washington, who sued for declaratory judgment and injunctive relief from two state laws, the first of which applied to all public employees, and the other only to teachers. The latter required a broad affirmative oath "by precept and example [to] promote respect for the

112. That is, the objectionable effects are those bearing on the affected persons' professional work as teachers (the "academic freedom" effects of the law). The obverse side of the same regulatory coin would be the objectionable "free speech" effects of the law, that is, the extent to which, insofar as one becomes a teacher subject to the disclaimer oath, one must then steer clear of political associations and activities others remain free to pursue. For an elaboration of the distinction, see William W. Van Alstyne, The Specific Theory of Academic Freedom and the General Issue of Civil Liberty, in Edmund Pincoffs, ed, The Concept of Academic Freedom (Univ of Texas, 1972). For an example of a federal regulation limiting first amendment rights of public employees but clearly not implicating academic freedom, see United States Civil Service Commission $v$ National Ass' $n$ of Letter Carriers, 413 US 548 (1973) (congressional restriction of civil service employees from certain forms of active personal involvement in political campaigns, upheld).

113. 389 US at 60 .

114. Id at 59 (emphasis added).

115. 377 US 360 (1964). 
flag and the institutions of the [United States and the] State."116 The companion statute, applicable to all public employees, imposed a broad disclaimer oath denying that the employee was a "subversive person," defined as one who knowingly joins or knowingly remains a member of any group that "advocates, abets, advises, or teaches any person" seeking to alter the form of state or national government by force or violence.

As neither statute had yet been construed by the state supreme court, Justices Harlan and Clark thought the case premature. In their view, the statutes were open to a narrow interpretation that might disarm them of any undue chilling effects. Writing for seven members of the Court, however, Justice White disagreed and held the statutes void in light of their immediate impact on those required to take and abide by the oaths. Moreover, the examples Justice White gave of the objectionable downstream effects likely to be generated by the statutes were examples of professional, anti-academic freedom steering effects, ${ }^{117}$ as distinct from ordinary anti-free speech effects. Significantly, too, in voiding the acts, Justice White noted:

Since the ground we find dispositive immediately affects the professors . . . and the interests of the students at the University in academic freedom are fully protected by a judgment in favor of the teaching personnel, we have no occasion to pass on the standing of the students to bring this suit. ${ }^{118}$

This passing remark merits more than a few words of its own. Students were not subject to either of the statutes, that is, students were not subject to any oath or other constraint under either statute. Yet students had presumed to appear as parties in interest to have both statutes declared void. What was their standing to do so? It was certainly not to stand in for the faculty (several faculty were already plaintiffs in the case). But the students claimed a separate (albeit related) standing because of what they alleged to be the direct effects of the laws on their own academic freedom. That is, the students claimed that the faculty would be inhibited by in terrorem effects of the oath from giving a full professional account of themselves in educational relationships with the students. Their claim as students was that it was not constitutionally permissible for the State of Washington to attempt to structure their education by putting the faculty under duress to compromise their professional interaction with students. Taken on its own terms, their claim of learning freedom was straightforward and strong. Justice White did not treat it as frivolous. To the contrary, his point is that since the academic freedom interests of the students were vindicated through the judgment in favor of the faculty plaintiffs, it was not necessary to determine whether the students could

116. 1955 Act, Wash Laws 1955, ch 377, 1931 Act, Wash Laws 1931, ch 103.

117. 377 US at 369-72 (examples include a faculty editor's reluctance to edit any scholarly journal with articles by Communist scholars from apprehension of appearing to act inconsistently with his oath; a reluctance to consult with such persons or attend a convention or present a paper with such persons present; an inhibition in class on any critical treatment of existing institutions, as inconsistent with the separate oath committing one affirmatively to promote respect for such institutions by precept and example).

118. Id at $366 \mathrm{n} 5$. 
have successfully maintained the action even if no faculty had been willing to come forward (perhaps from fear of targeting themselves). ${ }^{119}$

The student academic freedom claim, so identified in Baggett, albeit obliquely, is notable. It is not in tension with the claim of academic freedom advanced in the same case by the affected faculty. Rather, the two are exactly consistent in seeking an educational environment in which the good faith critical professional skills of the faculty are not foreclosed by hostile state action from being available to the students in the manner of instruction they receive and their professional interaction with the faculty. We shall shortly see several other cases where the argument is taken up (it might usefully have appeared much earlier, for example, in Scopes). The last case we note between 1957 and 1967, however, was not litigated along such lines.

At issue in the remaining case of this period, Shelton $v$. Tucker, ${ }^{120}$ decided in 1960, was an Arkansas statute ${ }^{121}$ requiring every teacher in each statesupported school or college annually to submit a list of all organizations in which the teacher had held membership or to which the teacher had contributed financially during the preceding five years, as a condition of continuing eligibility for (re)appointment each year. A number of noncomplying public school teachers and state college faculty members sued to have the requirement enjoined. Unlike any of the cases thus far reviewed, the requirement assailed in Shelton simply sought the requested information; that is, it did not probe the teaching of the faculty, impose any sort of disclaimer oath, or render anyone ineligible on grounds of any particular affiliation (knowing or otherwise). Nonetheless, on a closely divided (five-tofour) vote, the Supreme Court struck the statute down on first amendment overbreadth grounds.

Four Justices, including Frankfurter, found nothing facially amiss with the state requirement. In certain respects, moreover, the generality of the annual reporting requirement was arguably a point in its favor; the requirement did not imply that only certain affiliations or some affiliations more than others might trigger additional investigation and inquiry. Nor did it steer one away from certain groups, causes, parties, or political action groups.

For Justice Frankfurter (joined by Justices Harlan, Whittaker, and Clark), this was enough to conclude that the suit was premature. In the event that any public school or state college faculty members might be able to show subsequently that any of them, after complying, were not renewed in the course of annual review because of hostile use by school administrators of the information disclosed as an incident of the required annual listing, it would be

119. The claim, in first amendment terms, is entirely as appropriate for the students to assert in this kind of setting as an equivalent claim brought on behalf of students to contest the racial assignment of teaching staff also affecting the conditions of the education the state chooses to provide. For an example of just such a claim, see Rogers $v$ Paul, 382 US 198 (1965). And for an insightful general discussion, see Henry P. Monaghan, Third Party Standing, 84 Colum L Rev 277, 297-304 (1984).

120. 364 US 479 (1960).

121. Second Extraordinary Session of Ark Gen Assembly of 1958, Act 10. 
timely then, and not earlier, to check the statute's application on strict first amendment grounds. Since, however, the comprehensive disclosure requirement was on its face relatable to at least some few uses that might be entirely proper (for example, some kinds of organizational affiliations or contributions could provide grounds for concern arising from apparent conflicts of interest, or at least furnish reason for inquiry), the teachers could not claim a first amendment right to associational secrecy. For Justice Frankfurter, in brief, the teachers' claims went too far. In defending his position, moreover, Frankfurter also made the following observation: "If I dissent from the Court's disposition in these cases, it is not because I put a low value on academic freedom. . . . It is because that very freedom, in its most creative reaches, is dependent in no small part upon the careful and discriminating selection of teachers." 122 The majority, in reaching the opposite conclusion on the main issue, was not overall at odds with Frankfurter's general view. Rather, the majority emphasized that the lack of any tenure system under Arkansas law put every teacher at fresh risk each year, with no burden on a nonrenewing school to do more than send notice that the services of a given teacher were no longer desired without obligation to say why. Against the factual background of recent massive resistance to desegregation in Arkansas, and the expressed anxiety of the plaintiffs that in these circumstances the disclosure laws would intimidate teachers affected by them to abandon membership and financial support for certain voluntary organizations such as the National Association for the Advancement of Colored People rather than face the risk of covert retaliatory use of the information they would be required to supply, the majority held that the state's interests in forced disclosure were insufficient to sustain the requirement on its face. They regarded the requirement as too indiscriminate. Emphasizing the lack of confidentiality, the lack of procedural protections (that is, tenure), and the general atmosphere of public hostility, and quoting elaborately from Wieman and from Sweezy, the Court struck down the Arkansas statute. Principally, however, the emphasis of the decision is more of a piece with the opinion in Pickering, since its stress is on the rights of those who teach not to be put under duress to forego ordinary political rights of association and citizen speech. Only secondarily is Shelton an academic freedom case.

\section{B. $(1968-1978)$}

Nine cases in the Supreme Court report usages of "academic freedom" in constitutional litigation during the eleven years bounding 1968-1978. As in the preceding section, not all are equally germane. But part of what one gains from an unhurried review is some clearer sense of what counts as an academic freedom interest, as against an ordinary (albeit strong) free speech concern as such. So it is not useless to see some instances of the distinction at work, as in

122. 364 US at 495-96. 
some measure we already have. As we have already had occasion to notice, moreover, there are instances in which both descriptions of the interest at issue may be opposite. ${ }^{123}$

Some of the cases decided during this period are separately interesting, moreover, in reporting constitutional usages of academic freedom entangled with other constitutional clauses and issues. As one example, two cases measure the extent to which conditions of academic freedom or the lack thereof may limit the extent to which church-affiliated schools and universities may or may not receive direct fiscal support disbursed by the state. As a different example, the last case we consider here, Board of Regents of The University of California $v$. Bakke, draws on a claim of academic freedom in attempting to reconcile a state university admissions policy with the fourteenth amendment. The issue addressed by the Court in Bakke is the extent to which public universities may use race as a partial determinant of who shall attend the state university, claiming the power to do so as a valid exercise of academic freedom. But we begin with something much more obviously connected to the first amendment, the Court's 1969 decision in Tinker v. Des Moines School District. ${ }^{124}$ Tinker was a major decision arising under the first amendment, importing free speech rights onto the premises of public schools in a manner and to an extent not previously secured in any decision by the Supreme Court.

At issue in Tinker was a claim brought on behalf of three public high school and junior high school students (respectively sixteen, fifteen, and thirteen years old). Through their parents, who warmly supported their children's actions, they sued in federal court to forestall school penalties from being imposed upon them following their suspension for defiance of a school district rule forbidding armbands from being worn on campus. The plaintiffs' position was that the rule was an unwarranted restriction on their rights of personal and political expression. That the restriction was limited to the premises of the school, they insisted, did not mean that it should therefore be sustained. Rather, plaintiffs argued, absent some justification more compelling than a flat policy preference to disallow such activity on school grounds, the rule ought to be seen as an impermissible prior restraint on their rights of free speech. By a majority of seven to two (Justices Black and Harlan dissenting in separate opinions), the Supreme Court agreed.

Writing for the majority, Justice Fortas held that the first amendment did apply directly to the public school premises, that is, that no cordon sanitaire could be thrown up around it forbidding political expression on the premises by those in attendance during the school day. This first holding was a major step by the Court, quite similar in respect to students, to Sullivan in respect to the press. No previous case had gone so far. Then, advancing to the particular facts of the case, Justice Fortas held that the activities of the students (wearing black armbands on school grounds during the school day as

123. See, for example, note 112 and accompanying text.

124. 393 US 503 (1969). 
a personal, silent expression of reproach of U.S. engagement in Vietnam) were not subject to school restriction beyond that reasonably necessary to keep them from disrupting the program and activities of the school. Justice Fortas concluded that the scanty record did not reveal sufficient evidence of anything the school board might have relied on stronger than an "undifferentiated" 125 anxiety of adverse reaction to the students' behavior, and that this was simply not enough under the circumstances. The lower court decision was reversed.

In practical effect, the Supreme Court granted the plaintiffs a declaratory judgment entitling them to talk politics on their high school or junior high school campus-even by wearing armbands-in the absence of identifiable clear signs of adverse effects that might justify more tailored restrictions by the school administration. ${ }^{126}$ In the course of his wide-ranging opinion (two Justices concurred only narrowly), moreover, Justice Fortas wrote aggressively in criticism of student speech-restrictive public school board policies at large. He prefaced his analysis with the following passages, which came to be much quoted in other cases:

First Amendment rights, applied in light of the special characteristics of the school environment, are available to teachers and students. It can hardly be argued that either students or teachers shed their constitutional rights to freedom of speech or expression at the schoolhouse gate. This has been the unmistakable holding of this Court for almost 50 years. $\left[{ }^{127}\right]$. . . In our system, state operated schools may not be enclaves of totalitarianism. [S]tudents may not be regarded as closed-circuit recipients of only that which the State chooses to communicate. They may not be confined to the expression of those sentiments that are officially approved. ${ }^{128}$

Some of the Court's phrases in these passages fit well with strong academic freedom claims (for example, "[i]n our system, state-operated schools may not be enclaves of totalitarianism . . . students may not be regarded as closedcircuit recipients of only that which the State chooses to communicate"). ${ }^{129}$ They fit well, that is, with several points we have already derived in relating student and faculty academic freedom from Baggett, Keyishian, and cases of a like sort. They match up strongly also with other portions of our general review: that like the post, the state may give up public education when it chooses; but while carrying it on, the state is not sole master of what students are free to learn, whether on their own initiative or in interaction with those free to teach.

125. Id at 508 .

126. It is likely that a restriction on carrying one's political insignia into the classroom might well have been sustained, though a campuswide ban per se fails.

127. This was not entirely true. Indeed, Tinker's significance was that it established for the first time that, in some measure, public school premises cannot be restricted as a forum for political expression by students. Since Tinker there has been some erosion, though Tinker has not been overruled. See, for example, Bethel School District No. 403 v Fraser, 478 US 675 (1986) (student disciplined for off-color remarks as part of campus campaign speech on behalf of another student; Tinker heavily qualified). See also Hazelwood School District v Kuhlmeier, 484 US 260 (1988) (principal's unilateral and substantial censorship of student-managed, faculty-supervised newspaper sustained, 5 to 4$)$.

128. Tinker, 393 US at 506, 511.

129. Id at 511 (emphasis added). 
Still, allowing for all this, Tinker is not focused on academic freedom, ${ }^{130}$ certainly not in the profile that has thus far stretched from Adler through Keyishian, Whitehill, and Baggett. Rather, Tinker represents a strong first amendment judgment by the Court respecting general free speech claims by students during hours of compulsory attendance at publicly run schools, rather than anything more subtle. It is an example of a strong view of general first amendment free speech rights in an open society, but not more. ${ }^{131}$

Four years after Tinker, in 1972, the Court reviewed a related first amendment claim by a group of college students in Healy $v$. James. ${ }^{132}$ A chapter of Students for a Democratic Society ("SDS") had applied for official recognition as a student organization at Central Connecticut State College ("CCSC") in 1969. That status was sought in order to qualify the organization to place announcements of meetings or rallies in the student newspaper, to post notices on campus bulletin boards, and "most importantly"133 (to quote Justice Powell), to use campus facilities for holding meetings. Recognized groups already included the Young Republicans, Young Democrats, Young Americans for Freedom, and the Liberal Party. Despite a six-to-two vote by the college Student Affairs Committee (four students, three faculty, and the dean of students) recommending approval, the college president disapproved the group's application.

The student organizers sued in federal district court to enjoin, on first amendment grounds, the president's refusal. The president defended his decision on the basis that a line should be drawn disallowing campus status "to any group that 'openly repudiates' the College's dedication to academic freedom," 134 which, arguably, SDS did. SDS chapters had been involved in episodes of trashing and disruption at some other colleges. In the SDS view, colleges as well many other social, economic, and political structures in the United States were rigged against the interests of the poor. SDS was itself skeptical and contemptuous of the conventional view of academic freedom, a view they regarded as protecting the status quo. Influenced strongly by Herbert Marcuse's writings (for example, Repressive Tolerance ${ }^{135}$ ), many SDS members believed that prevailing first amendment doctrine was itself vicious

130. The sole actual mention of academic freedom in Tinker is a footnote reference to a law review note, Note, Academic Freedom, 81 Harv L Rev 1045 (1968) (using the phrase in its title). 393 US at $506 \mathrm{n} 2$.

131. The dissenting opinion by Justice Harlan is useful in elaborating this point. Id at 526 . Also, in saying that "teachers [do nol] shed their constitutional rights to freedom of speech . . at the schoolhouse gate," id at 506, Justice Fortas is correct in the sense the Pickering case shows. The dictum may seem to go further, however, and to imply that public school teachers may also use school premises as the students used them, for example, to wear political armbands; but that is doubtful (nor would academic freedom necessarily embrace the idea). Rather, it is likely a public school rule forbidding teachers to wear political armbands or buttons during working hours on school premises or in classrooms would-and should-be sustained.

132. 408 US 169 (1972).

133. Id at 176 .

134. Id.

135. Robert Paul Wolff, Barrington Moore, Jr. \& Herbert Marcuse, A Critique of Pure Tolerance 80117 (Beacon Press, 1969). 
because it enabled entrenched elites to exploit others by perpetuating a myth of an open marketplace of ideas, which the elites dominated for their own ends. SDS did not agree that moral people should tolerate the free circulation of evil ideas; rather, moral people should act to disrupt their presentation when necessary to prove they were no longer acceptable in the classroom or anywhere else.

Despite all this, however, in seeking recognition at CCSC, the SDS chapter had actually filed an unprepossessing statement of educational purposes. When pressed for further information as to whether they might engage in interrupting classes, they replied only that their action would "be dependent upon each issue."136 The president decided that this was not adequate and disapproved their request. After still further campus hearings on the question of recognition (hearings mandated by the district court), the president renewed his disapproval on grounds that recognition of the SDS chapter would be "contrary to ... orderly process[es] of change" and would present a "disruptive influence" to the college. ${ }^{137}$ The district court sustained the president. The court of appeals affirmed the district court. The Supreme Court unanimously reversed in an opinion written by Justice Powell.

In his opinion, Powell quoted Tinker and declared: "At the outset we note that state colleges and universities are not enclaves immune from the sweep of the First Amendment. [W]e break no new constitutional ground in reaffirming this Nation's dedication to safeguarding academic freedom." 138 Then, after noting that the student organization had complied with the college's filing requirements and that the president's adverse decision operated as a prior restraint under the circumstances, Justice Powell placed the burden of justification on the college and held that it had not been met. Any risk of disruption or intimidation was inchoate, not sufficiently clear nor present to justify refusing to allow the chapter to form and meet on campus. The philosophy of the organization, even assuming it countenanced violence and disruption, "affords no reason" for disallowing it to persuade others of the truth of its point of view, so long as it in fact operated on campus in an orderly fashion, even as the Young Democrats or Young Americans for Freedom already did. ${ }^{139}$ Powell's statement was exceedingly strong in applying the first amendment. It virtually repeated the position Holmes and Brandeis had taken a half century earlier as a general first amendment rule: "Whether petitioners did in fact advocate a philosophy of 'destruction' [is] immaterial. The College, acting here as the instrumentality of the State, may not restrict speech or association simply because it finds the views expressed by any group to be abhorrent."'140

136. Healy, 408 US at 173.

137. Id at 179 .

138. Id at 180 (citations omitted).

139. Id at 187 .

140. Id. 
Concern with respect to actual acts of disruption or actual acts of intimidation, or with respect to acts to deprive others of their opportunity to speak or be heard, is entirely proper, Powell declared firmly for the Court. But, quoting from Tinker again, Powell held that definite actions, or at least discernible threats of such actions, must materialize to warrant sanctions by the college, including revocation of recognition. A ban of the organization in advance of any untoward activity or any specific threat could not stand, consistent with the fourteenth amendment's application of the first amendment to the state college.

At the end, Powell hedged only in one respect. The decisions of the lower courts were reversed, but the case was remanded for further proceedings to determine whether the SDS group would express a minimal willingness to be bound by such campus regulations as the Court had already indicated the college might maintain and strictly enforce (against disruption, invasion of classrooms, or interference with other speakers, for example). The Court thus left the possibility open that the group might be banned if, notwithstanding a request to do so, it declined to submit a statement of willingness to be bound by the valid rules that the college maintained for the protection of academic freedom and for general order on campus. ${ }^{141}$

Healy, even more than Tinker, is an exceptionally strong first amendment decision, albeit confined to state colleges (as Tinker is confined to public schools). Neither implies that unaffiliated outside groups may willy-nilly wedge themselves onto public school or state college premises. On the other hand, neither case (certainly, not Healy) permits the college to draw a sharp line according to the ideological auspices of student groups free to claim campus breathing space of their own up to the point of actual threats, acts of intimidation, actual acts of disruption, or interference with the educational program or rights of others on campus, as both cases are at pains to say. A concurring opinion by Justice Douglas carried the point even farther than did that by Justice Powell. Douglas defended the radical heterodoxy of student groups as a check even as to the faculty itself:

141. Extracting such a commitment to observe the rules necessarily puts groups such as SDS under a strain. In the circumstances, the act of making such an affirmative expression is inconsistent with the group's view that such rules are not entitled to respect (because, in SDS's opinion, they constitute a parliamentary façade by means of which dominant classes maintain elite control). It may be argued that refusal to express acceptance of such rules may not be sufficient grounds to ban the group, though enforcement of the rules would be utterly sound. The problem is akin to a pledge of allegiance test. Compare these two statements:

(a) In applying for recognition on campus, we accept and agree to observe all college rules applicable to recognized student organizations;

(b) In applying for recognition on campus, we acknowledge that the College has a set of rules applicable to recognized student organizations, and we understand that we will not be regarded by the College as exempt from them.

The second form effectively records the fact of notice of the rules; it makes clear that recognition in no way implies waiver by the college of its rules. The first form, requiring acceptance of the rules, however, seeks a concession respecting the accepted legitimacy of the rules; somewhat like a "pledge of allegiance," it is more doubtful on that same account. 
Some [of the faculty] have narrow specialities that are hardly relevant to modern times. History has passed others by, leaving them interesting relics of a bygone day. More often than not they represent those who withered under the pressures of McCarthyism or other forces of conformity and represent but a timid replica of those who once brought distinction to the ideal of academic freedom. ${ }^{142}$

At least passingly related to Tinker and to Healy, moreover, is Jones $v$. State Board of Education, ${ }^{143}$ denied review in the Supreme Court in 1970. At issue in the case was a petition for certiorari, brought by a state college student who had been suspended by the college. He claimed it was done solely because he distributed a campus pamphlet for the Student Nonviolent Coordinating Committee ("SNCC"), urging a student registration boycott-an activity he claimed the first amendment protected. After hearing oral argument, the Court dismissed the petition for lack of sufficient evidence in the record regarding the actual basis of the student's suspension (it appeared in the course of oral argument before the Court that he may have been suspended for having lied to the campus disciplinary committee rather than for having distributed the pamphlet). So, technically, the case altogether washed out. But one Justice, Douglas, filed a dissent.

Douglas did not relate the student's actions to academic freedom (the phrase "academic freedom" actually appears solely in the student's pamphlet, reprinted in the case), but his opinion treats those actions as protected by the first amendment nevertheless. That the pamphlet statements may have been "ill-tempered and in bad taste," or "even strongly abusive," 144 Douglas says, may not on those grounds enable the state college to have the pamphleteer suspended or dismissed. On the other hand, Douglas insisted, " $t]$ his does not mean that free speech can be used with impunity as an excuse to break up classrooms, to destroy the quiet and decorum of convocations, or to bar the constitutional privileges of others to meet together in matters of common concern." 145 In brief, the Douglas opinion does not break new ground, but it does represent a very strong view of student-citizen, on-campus free speech.

Tinker, Healy, and Jones are, in sum, strong first amendment cases. All treat students as possessing assertable first amendment rights on campus. All involve student engagement in some conspicuous form of personal political expression. In many respects, their parallelism to Sullivan and Pickering is quite complete: they are animated by a strong first amendment breathing space rationale extended in three dimensions at once.

The first dimension is in the holding that the first amendment disallows public authority to cordon off public school or public college premises by any strict limitation restricting students in attendance to "educationally germane" speech alone; it appears specifically in the Court's express, reiterated proposition that students need not leave their involvement in general political

142. Healy, 408 US at 196-97.

143. 396 US 817, cert dism, 397 US 31 , reh denied 397 US 1018 (1970).

144. 397 US at 33 (Douglas dissenting).

145. Id at 33-34. 
debate at the school gate. ${ }^{146}$ The second dimension of the breathing space rationale is that the extent to which the first proposition holds true is more substantial than one might have supposed, in both a procedural and in a substantive sense. So, the cases suggest, procedural limitations (for example, those generally concerned with time, place, and manner of on-campus expression) must not sweep wider than reasonably warranted in order to avoid material kinds of interference with the orderly campus environment. Both Tinker and Healy (and certainly Douglas's dissent in Jones) strongly so suggest. Substantively, the rules may generally not pick and choose "acceptable" philosophies to be presented on campus through student oncampus expression; nor, evidently, may common forum advantages of operating on campus (for example, as a recognized student group) be withheld because of misgivings associated with a particular group's ideological bent or because of strong public disapproval. Third, these propositions evidently hold, in some degree, even in respect to quite young persons (for example, in Tinker, one of the students was only thirteen). While it may be doubtful whether these first amendment beachheads involve student academic freedom in any ordinary understanding (that is, compare these cases with the academic freedom student claim in Baggett), one may rightly pause in thinking the matter through. They do assure students of some right to fashion what is in some loose sense a constitutionally protected cocurriculum on campus-the teaching agendas and learning experiences of their own actions-carried on in a manner that may well influence the official curriculum as well. Obliquely, therefore, if not directly, they do secure a kind of anarchistic student academic freedom under first amendment auspices one might be mistaken to discount or dismiss.

Two years after the dismissal of certiorari in Jones, the Court denied certiorari in a case in which Justice Douglas again dissented, President's Conncil v. Community School Board.147 The case is an inconclusive forerunner to an address by the full Court of the same issues in 1982, ${ }^{148}$ but Douglas's dissent is noteworthy because it bears intimately on his exceptional views in Healy and Jones. It also virtually completes the twenty-year cycle of Douglas opinions on the larger subject, beginning with his seminal dissent in the 1952 Adler case, the first explicit use of academic freedom in the Supreme Court.

President's Council had been commenced in federal district court by a combination of plaintiffs: a junior high school principal, a librarian from one of the affected schools, and several parents suing for themselves and their children. ${ }^{149}$ Their object was to secure a mandatory injunction ordering the

146. Tinker, 393 US 503.

147. 457 F2d 289 (2d Cir 1972), cert denied, 409 US 998 (1972).

148. Board of Educ., Island Trees v Pico, 457 US 853 (1982); see notes 237-49 and accompanying text.

149. Had the publisher and author joined the case as plaintiffs, the additional issue would have been joined whether their freedom of speech and press interest-to reach willing readers-was violated by the state action interposed by the school board's banishment of the book from public school library shelves. (To frame the issue in this way is not to imply a certain answer, but it may 
school board to return a particular book ${ }^{150}$ to the school library shelves, from which the school board had ordered it removed.

Noting that the book remained available to those students presenting a written request by their parents, the court of appeals (in affirming the district court's dismissal of the case) held that the alleged violation of academic freedom was no more than "miniscule" (sic), if real at all: the court regarded the whole matter to be much too trivial to "elevate this intramural strife to first amendment constitutional proportions." 151 Dissenting from the Supreme Court's subsequent denial of certiorari, however, Douglas strongly disagreed:

Academic freedom has been upheld against attack on various fronts. . . The first amendment is a preferred right and is of great importance in the schools... . Are we sending children to school to be educated by the norms of the School Board or are we educating our youth to shed the prejudices of the past, to explore all forms of thought, and to find solutions to our world's problems? ${ }^{152}$

Douglas left it quite unclear whose academic freedom (presumably that of the students?) had been abridged. We shall see later, in the Court's treatment of the 1982 Pico decision, what became of this species of dispute when it was more fully discussed. The first amendment importance of the dissent is that Douglas regarded the school board action as reviewable at least to see whether the state was acting through its public school system to restrict the availability of ideas out of a community preference for insulating conventional wisdom from critical appraisal (albeit in the form of a particular book on the library shelf rather than in the form of the remarks of a classroom teacher); it is not at all clear that he was wide of the mark in voting to have the Court take a closer look at the case. Indeed, his dissent is related in this respect to a major Supreme Court case of this same period, Epperson v. Arkansas, ${ }^{153}$ decided in 1968.

Epperson was a reprise on Scopes; it dealt with a virtually identical state criminal statute, adopted in Arkansas the year after the Tennessee court had sustained the Tennessee act. Like that act, the Arkansas statute forbade

any teacher . . in any University, College, Normal, Public School, or other institution of the State, which is supported in whole or in part from public funds . . . to teach the theory or doctrine that mankind ascended or descended from a lower order of animals [or to use any textbook] that teaches the [same theory or doctrine]. ${ }^{154}$

Notwithstanding this statute, a public school teacher, Susan Epperson, did assign such a textbook for use in her high school biology class; she sued in state court for a declaratory judgment to determine whether she could use the

provide an additional first amendment link with the other plaintiffs asserting compatible interests in lifting the ban.)

150. Piri Thomas, Down These Mean Streets (Knopf, 1967).

151. 457 F2d 289, 292 (2d Cir 1972).

152. President's Council, 409 US at 999-1000 (Douglas dissenting).

153. 393 US 97 (1968).

154. Ark Stat Ann $\S \S 80-1627$ to 1628 (1960 Repl Vol). Note that just as was true of the Tennessee statute, the restriction also applied at the university level. That being so, any suggestion that the statute merely meant to shield especially young children from emotional conflict (between subjects addressed in school and family loyalties) would seem entirely farfetched. 
textbook without threat of discharge or criminal prosecution. The state chancery court, responding to the numerous U.S. Supreme Court decisions we have previously canvassed, held that the state could not "restrict the freedom to learn, and restrain the freedom to teach" by categorical criminal law censorship of this sort, even within its own schools and colleges. ${ }^{155}$ As it was to turn out, however, only the state chancery court's opinion applied first amendment-academic freedom as the principal basis for decision; somewhat ironically, and altogether anticlimactically, neither the state supreme court nor the U.S. Supreme Court did.

The state supreme court gave the entire case short shrift. In a twosentence per curiam reversal of the chancery court, the state supreme court treated the state as free to set the terms of teaching and learning in public schools and public universities as it wished (just as the Tennessee Supreme Court had done in the 1920s); it peremptorily upheld the restriction as "a valid exercise of the state's power to specify the curriculum in its public schools."156 In brief, the Arkansas Supreme Court treated the teachers as confinable in their classroom coverage exactly as the state legislature preferred; correspondingly, the dependent freedom of the students, in their interactive learning relationships with the teachers, was implicitly cut off as well. Epperson thus went to the Supreme Court as an excellent first amendment academic freedom case. The case was as strong-perhaps stronger-than that joining the issues we noted in Baggett $v$. Bullitt, ${ }^{157}$ albeit drawn in the setting of secondary education, rather than in state colleges and universities.

In the Supreme Court, Justice Fortas (writing for six members of the Court) initially addressed the case in strong first amendment, academic freedom terms. He invoked Keyishian ${ }^{158}$ and Shelton v. Tucker ${ }^{159}$ to settle the full relevance of the first amendment to the classroom. He likewise referred to Meyer, ${ }^{160}$ describing it as a case in which "the Court did not hesitate to condemn under the Due Process Clause 'arbitrary' restrictions upon the freedom of teachers to teach and of students to learn." 161 But, having set up the case in these strong, promising terms, Justice Fortas then deflected the actual decision into a narrower channel. He concluded that it was not necessary to strengthen the constitutional constraint upon the powers of the state government to operate public schools and universities as it wished, even though the state attorney made virtually no effort to defend the law (he more or less desultorily adhered to the state supreme court's view that no defense

155. 393 US at 100 , quoting unreported opinion of Chancery court.

156. 242 Ark 922,416 SW2d 322 (1967).

157. 377 US 360 . See note 115 and accompanying text.

158. 385 US 589 (1967).

159. 364 US 479 (1960).

160. 262 US 390 (1923).

161. Epperson, 393 US at 105. This was, however, slightly careless of Justice Fortas; Meyer, it will be remembered, dealt with an effort to restrict German language instruction in private schools, not (merely) public schools, as here. 
was needed-that is, that the state could do as it liked as to its own schools and colleges-a view clearly incorrect under pre-existing Supreme Court decisions). Rather, Justice Fortas concluded, whatever valid reasons a state might adduce in some circumstances, to justify the way it has allocated scarce educational resources or has taken into account the age of students (for example, the appropriateness of reserving some subjects to higher age groups), no such considerations accounted for the categorical, across-theboard exclusion at issue. Instead, Fortas held, the Arkansas statute had no purpose other than to serve the interests of the dominant religious faith of the region by forbidding public classroom instruction inconsistent with its tenets. ${ }^{162}$ A legislative preference merely to protect a dominant religion is disallowed as contrary to the first amendment's establishment clause. Accordingly, the court struck down the Arkansas statute specifically on that ground. 163

The decision in Epperson, however, was weakened by the surprising concurrence filed by Justice Black (surprising because, along with Justice Douglas, Black had been most forceful in the long list of academic freedom cases and regulations in the 1950s and 1960s). In Justice Black's view, the statute was void only because the state supreme court had left it uncertain whether a teacher was "forbidden to mention Darwin's theory at all or [was forbidden only] from contending that it was true." 164 If the statute meant to prohibit any mention, then, while it might be valid as thus understood, the state court needed to make clear the extent of the statutory prohibition, in order that teachers not be made to guess. For Black, therefore, the vice of the

162. Id at 107. Note, again, that the statute applied uniformly to public higher education as much as to secondary education in Arkansas, thus-on its face-proposing no distinction in respect to secondary education, that is, no basis for crediting a rationale applicable to the one level of schools vis-á-vis the other, since the legislature made no such distinction at all. The foreclosure of any academic presentation respecting evolution of the species (like the equivalent banning of books, journals, or other publications containing like material through the mails) should be the easiest kind of first amendment case under these circumstances. Of course, to the extent that the restriction was also enacted because those having the power to do so wanted the topic and materials suppressed as a set of blasphemous ideas, Fortas was not wrong to fault the statute separately under the establishment clause. (The case is no different in that regard than the use of state power to forbid the publication or republication of Galileo's telescopic evidence tending to confirm Copernican astronomy; that the ban is limited to state-supported educational institutions should make no difference at all.) For a recent and excellent review of blasphemy and the first amendment, see Robert C. Post, Cultural Heterogeneity and Law: Pornography, Blasphemy, and the First Amendment, 76 Calif L Rev 297 (1988).

163. There is and can be no doubt that the First Amendment does not permit the State to require that teaching and learning must be tailored to the principles or prohibitions of any religious sect or dogma. ... In the present case, there can be no doubt that Arkansas has sought to prevent its teachers from discussing the theory of evolution because it is contrary to the belief of some that the Book of Genesis must be the exclusive source of doctrine as to the origin of man. . . . No suggestion has been made that Arkansas' law may be justified by considerations of state policy other than the religious views of some of its citizens. ... The law's effort was... a an attempt to blot out a particular theory because of its supposed conflict with the Biblical account, literally read.

393 US at 106-09. Justice Fortas's sole usage of "academic freedom" appears in footnote citations of law journal titles (id nn10,13).

164. Id at 112 (Black concurring). 
law was its threat of criminal sanctions against one who might guess wrong; putting teachers at risk in that way was unfair-a denial of due process.

At one point, Justice Black made an unexceptionable observation that teachers may not, as a matter of constitutional right, commandeer the classroom in whatever way suits their fancy. ${ }^{165}$ At another point, however, he veered very much in the direction of moving all the way from that undisputed basic proposition virtually to the rhetoric of the right-privilege distinction the Court had long since rejected:

I am ... not ready to hold that a person hired to teach school children takes with him into the classroom a constitutional right to teach sociological, economic, political, or religious subjects that the school's managers do not want discussed. . . I question whether it is absolutely certain, as the Court's opinion indicates, that "academic freedom" permits a teacher to breach his contractual agreement to teach only the subjects designated by the school authorities who hired him. ${ }^{166}$

As though to underscore the extreme implications of Justice Black's view (and to separate himself from them), Justice Stewart authored a separate, onepage concurring opinion. Stewart distanced himself from Justice Black by declaring that he believed it would violate the first amendment's free speech clause (not merely the establishment clause) for a state statute to forbid public school teachers "so much as to mention the very existence of an entire system of respected human thought" (he expressly includes "Darwin's theory"); he then wrote that "since Arkansas may, or may not, have done just that, I conclude the statute before us is so vague as to be invalid under the Fourteenth Amendment." 167 To restate his proposition accurately, had it been clear that the statute did forbid any mention of Darwin's theory in the treatment of subjects to which it would be relevant, Justice Stewart would have held the statute invalid on that account-not for vagueness (Justice Black's sole objection) but for unconstitutional overbreadth (an objection Black evidently would not have endorsed). And that objection, consistent with the pre-existing case law of the Court on academic freedom and the first amendment, certainly seems correct.

Indeed, in a roundabout but nonetheless instructive fashion, two principal cases decided by the Court during this decade strongly confirm Justice Stewart's position in Epperson. The earlier case, Tilton v. Richardson, ${ }^{168}$ was decided in 1971. It reviewed the substantive constitutionality of an act of Congress providing for capital construction grants for which private as well as public colleges and universities were eligible; the grants were targeted for specified kinds of campus buildings and facilities such as classrooms, science laboratories, and libraries. The immediate question was whether religiously affiliated colleges could participate in these grants despite the first amendment provision respecting the separation of church and state. In a closely divided vote, five-to-four, the Supreme Court held that they could.

165. Id at 113 .

166. Id at 113-14.

167. Id at 116 (Stewart concurring).

168. 403 US 672 (1971). 
Significantly, in sustaining the constitutional eligibility of the particular religiously affiliated colleges and universities at risk in the case, Chief Justice Burger, writing for the majority, expressly used academic freedom as the constitutional litmus test: whether despite the formal governance of certain colleges by religious bodies, they were nonetheless "characterized by an atmosphere of academic freedom rather than religious indoctrination" such that they compared favorably with other eligible institutions in that respect and ought not be characterized as primarily agencies of a church. ${ }^{169}$ So, at various points in his opinion, the Chief Justice noted that non-Catholics were admitted as students, ${ }^{170}$ that non-Catholics were members of the faculty, ${ }^{171}$ that the schools "introduced evidence that they made no attempt to indoctrinate students or to proselytize," 172 that none required attendance at religious services, ${ }^{173}$ and that the theology courses "are taught according to the academic requirements of the subject matter and the teacher's concept of professional standards." 174 In elaborating on these observations, he went on:

[T] hese four schools subscribe to a well-established set of principles of academic freedom and nothing in this record shows that these principles are not in fact followed. . . . Although appellants introduced several institutional documents that stated certain religious restrictions on what could be taught, other evidence showed that these restrictions were not in fact enforced and that the schools were characterized by an atmosphere of academic freedom rather than religious indoctrination. All four institutions, for example, subscribe to the 1940 Statement of Principles on Academic Freedom and Tenure endorsed by the American Association of University Professors and the Association of American Colleges. . . . Many churchrelated colleges and universities are characterized by a high degree of academic freedom and seek to evoke free and critical responses from their students. ${ }^{175}$

In the related case decided five years later, Roemer $v$. Maryland Public Works Board, ${ }^{176}$ the same requirement was (nominally) applied. The case involved a taxpayer challenge to a state funding program under which private colleges within the state might apply for state financial aid equal to 15 percent of the per-student amount provided to the state college system. Writing for a plurality of the Court, Justice Blackmun first observed that more than twothirds of the eligible private colleges had no religious affiliation (the point of his observation being, presumably, to negative any suggestion that the program was but a disguised effort to support religious institutions). Then, as to those having such an affiliation, he noted, each was characterized by a "high degree of institutional autonomy," none received funds from or reported to the Catholic Church, and "[e]ach college subscribe[d] to, and abide[d] by, the 1940 Statement of Principles on Academic Freedom of the American Association of University Professors."177 Again, the proposition

\footnotetext{
169. Id at 681 .

170. Id at 686 .

171. Id at 687.

172. Id.

173. Id

174. Id at 686 .

175. Id at $681-82,686$.

176. 426 US 736 (1976).

177. Id at 755-56.
} 
was that these are appropriate expectations a court or a public agency would use to measure the constitutional eligibility for state assistance of private colleges and universities. Moreover, no member of the Court in either case entertained the proposition that state schools, controlled directly by government, could somehow be exempt from these standards of academic freedom when private schools seeking public help would not be. Nor is there any logical reason to explain why state schools should be exempt. In this sense, then, Justice Stewart's view in Epperson also seems entirely sound, even treating Epperson as a straightforward academic freedom case. ${ }^{178}$

As in Tilton and Roemer, express reference to the 1940 Joint Statement of Principles (or, rather, an interpretative report of the 1940 Statement by Committee A) also appeared in an additional Supreme Court case decided during this period (1968-1978), reviewing a faculty member's first and fourteenth amendment claims. The case, Board of Regents $v$. Roth, ${ }^{179}$ was in part a reprise of the Pickering case. As in Pickering, the terminated faculty member sued for reinstatement on grounds that his termination (at the Oshkosh campus of the University of Wisconsin) was prompted by his public criticism of the university administration-criticism that, consistent with the Court's decision in Pickering, he believed could not be used to affect his appointment. The district court concluded that it was unnecessary to reach a decision on that question (unlike Pickering, where the basis for the school board's action was a matter of record, in Roth the regents did not admit that the faculty member's public criticism was a consideration in their decision; the burden thus fell on Roth to show that it was). Rather, the court held, Roth's status on the faculty as a tenure track appointee sufficiently distinguished him from a one year visitor or other kind of ad hoc contract appointee such that some kind of intramural procedure prior to his effective termination was

178. The dissents in Tilton and Roemer did not disagree with the discussion in the text. Rather, the dissents took strong exception to the majority's conclusions respecting the evidence used to describe the private schools as truly satisfying the Court's own criteria. 403 US at 689 (Douglas dissenting); 426 US at 769-72 (Brennan dissenting); id at 772.74 (Stewart dissenting). And, at least in Roemer, the dissents seem to have the better of the argument by far. For example, in Roemer, Justice Stewart noted that in Tilton the Court found from the record positive evidence that "the theology courses were taught as academic subjects," id at 773-74 (emphasis added); no such positive evidence was produced in Roemer; further, in Roemer, all members of the religion or theology faculty at two of the colleges were Catholic clerics-a point making the absence of positive findings (in respect to the teaching of those courses) additionally disturbing. As far back as our discussion of the Adler case, see notes 76-87 and accompanying text, note was taken of different (albeit often related and synergistic) ways in which the state itself might offend the first amendment in respect to faculty staff and academic freedom: not merely by direct command, or by chilling rule, as in Epperson on the one hand and as in Adler on the other hand, but also by preshaping a faculty that is nominally otherwise fully protected in its academic freedom. Stewart correctly identifies this issue, in Roemer, in this way: "Recognition of the academic freedom of these instructors does not necessarily lead to a conclusion that courses in the religion or theology departments at the five defendant [institutions] have no overtones of indoctrination." Id at 774. The point is the obvious one, that is, the staffing criteria of the college may already have done their work.

179. 408 US 564 (1972). See also Perry $v$ Sindermann, 408 US 593 (1972) (Roth applied, faculty member's aprofessional speech activities held to be protected by the first amendment, and case remanded to determine whether quasi-tenure status was sufficient to trigger 14 th amendment fair hearing pretermination due process rights). In Roth, the express, favorable reference to the Committee A Report appears at 408 US 579 n 17 . 
required in order to protect his academic freedom. The case advanced to the Supreme Court to consider the procedural issue separately. The Supreme Court then divided in three ways at once: one Justice (Douglas) agreed with the district judge's reasoning and result; two (Brennan and Marshall) would have gone even further to require hearings; and five voted, instead, to reverse.

In substantially agreeing with the district court, Justice Douglas reached a set of conclusions urged in an amicus brief the AAUP filed in the case. ${ }^{180}$ The brief's emphasis was essentially in two parts. The first part noted the hazard to academic freedom implicit in any peremptory power of the Wisconsin regents to nonrenew a faculty member's appointment without explanation. The second part noted that while tenure track appointees are necessarily at risk in some ways that tenured faculty are not at risk, they are also unlike oneyear visitors or fixed-term contract appointees. Appointment on a tenure track implies a more ongoing relationship than a simple term contract. The vast majority of tenure track first-year appointment contracts are routinely renewed precisely because the relationship is at this stage usually still ongoing; it would be odd if tenure track appointees typically were nonrenewed after a single year. This pattern held within the University of Wisconsin system-almost no one other than Roth on tenure track appointment was nonrenewed as early as he. The AAUP contended that the protection of the academic freedom of these faculty members required that before their tenure track status was ended, some procedural protection should be available, just as the district court had held. ${ }^{181}$ The Douglas opinion agreed. His own emphasis, moreover, was explicitly keyed to substantive first amendment academic freedom concerns. ${ }^{182}$ But the majority reversed the district court, and remanded the case for retrial. ${ }^{183}$

To be sure, the majority in Roth cast no retrospective doubt on its long line of cases protecting academic freedom as a subset of first amendment rights. Nor did it retract anything from its Pickering (free speech) line of cases. Even though Roth's speech may have been more involved with citizen-interest speech than with his teaching, research, or professional participation within the university, the Court left no doubt that insofar as his nonrenewal was improperly based on either sort of consideration, he could prevail in his action, once he proved his claim. But the Court detached that means of protecting his academic freedom-by suing and by proving affirmatively in court the improper basis of the regents' action-from the claim that his tenure track status entitled him to something more from the university than an

180. AAUP's Brief as Amicus Curiae, Board of Regents $v$ Roth, 408 US 564 (1972) (No 71-162).

181. See Procedural Standards in the Renewal or Nonrenewal of Faculty Appointments, 56 AAUP Bull 21 (Spring 1970). See also Roth $v$ Board of Regents, 310 F Supp 972, 979-80 (WD Wis 1970) ("Substantive constitutional protection for a university professor against non-retention in violation of his First Amendment rights . . is useless without procedural safeguards."). (The AAUP position was that such substantive constitutional protection was not "useless," but that it was nonetheless incomplete under the circumstances.)

182. 408 US at 579.84 (Douglas dissenting).

183. Id at 579 . 
unexplained pink slip, if academic freedom was not to be put unfairly at risk for persons in his position. Despite the AAUP's firm agreement with Roth, the Court held that this claim came up short as a matter of fourteenth amendment due process law. Effectively, the Court chose to regard Roth as though he had been a one-year or other term appointee and not on the tenure track at all, who had simply not been asked to stay on, despite the AAUP view that this kind of comparison elides an essential difference and falsifies a critical distinction in status and expectations. ${ }^{184}$

Given the Court's approach in Roth, however, this particular subject remains a significant area of professional concern; the Constitution has come around less than one might have hoped. ${ }^{185}$ Procedurally speaking, academic freedom remains caught in a crevice of vulnerability. To the extent that public sentiment prefers that those who teach shall be appointed only pursuant to an indefinite series of closed-end contracts, each (in theory) entirely new and terminal unto itself, without doubt the effect is necessarily one of inhibiting any professional departure from uncontroversial methods and substance, lest one find oneself out on the street with only a problematic right to sue. Roth, in recognizing no distinction between such appointees and tenure track faculty, widened that crevice even more. Given the commonsense basis on which such faculty might have been distinguished from strict term appointees (from whom they are in fact substantively distinguished in general educational practice), and given also the Court's general express emphasis on academic freedom as a core first amendment concern, Roth

184. In the AAUP view, tenure track appointees are by category and definition differently situated as an ordinary legal matter than closed-term appointees, visitors, or, indeed, faculty at institutions having no tenure system at all (for example, faculty all of whom never have anything more than each annual dead-end contract, regardless of how many such previous dead-end contracts each might already have had). Specifically, one who is appointed to a tenure track position in an institution embracing a tenure system is receiving assurance by the appointment that, absent some perceived deficiency in his or her professional performance, the expectation of appointment renewal and eventual review for tenure is objectively reasonable. This, ordinarily, is what appointment to the full time faculty on the tenure track means. (Exceptions qualifying that understanding are ordinarily few in number, for example, institutionwide financial exigency or a serious decline of enrollment in the department or discipline of one's specialty such that nonrenewal could occur though one's own work was considered to have gone very well.)

185. Despite Roth, moreover, the Court has not applied its logic uniformly since 1972. See, for example, Cleveland Board of Educ. $v$ Loudermill, 470 US 532 (1985); Amett v Kennedy, 416 US 134 (1974). (Both cases are, as noted by the dissents in each, indistinguishable from Roth; the status furnished the public employee was described conterminously with the procedures laid out in advance for ending that status, which procedures the public employer sedulously followed, exactly as in Roth. Nevertheless, in Loudermill and in Amett, the Court declined to treat the due process clause as selfreferentially limited. It held, rather, that whatever due process the due process clause itself would require would have to be provided even if it was more than the state had promised.) Perhaps part of the problem in Roth was the apparent failure of the AAUP adequately to stress to the Court the substantial difference between tenure track and simple term contract academic appointees. Even so, the total case law in this area is simply not consistent, even within itself, since Roth. (For four different discussions, see Richard A. Epstein, Unconstitutional Conditions, State Power, and the Limits of Consent, 102 Harv L Rev 4, 70-73 (1988); Stephen F. Williams, Liberty and Property: The Problem of Government Benefits, 12 J Legal Stud 3, 27 (1983); William W. Van Alstyne, Cracks in "The New Property": Adjudicative Due Process in the Administrative State, 62 Cornell L Rev 445 (1977); Frank I. Michaelman, Formal and Associational Aims in Procedural Due Process, in J. Roland Pennock \& John W. Chapman, eds, Nomos XVIII 126 (New York Univ Press, 1977)). 
remains an anomalous exception in the sweep of the cases we have reviewed. One reasonably could have expected it to come out the other way, even as the district court supposed.

In contrast with Roth and its concern with academic freedom and due process where an individual faculty member's position was in question is Regents of the University of Califormia $v$. Bakke, ${ }^{186}$ a highly publicized case decided in 1978. It is also the last case within the 1968-1978 period of review in which an express usage of "academic freedom" appears. The judgment in the Bakke case was determined by a single Justice, Lewis Powell, in an opinion in which no other member of the Court joined. ${ }^{187}$ At issue in Bakke was an admissions policy at the medical school of the University of California at Davis. Bakke had applied and been refused admission in 1973 and 1974, though his academic qualifications were substantially greater in every objective category than those averaged by thirty-two other students who had been admitted but with whom Bakke was never compared. ${ }^{188}$ Under the policy approved by the medical school faculty, he was not permitted to be compared with any of them for admission only because he was not American Indian, Asian, chicano, or black. The reason for disallowing such direct comparison, moreover, proceeded from the same baseline explanation: few, if any, of those insulated from comparison with Bakke might have been deemed more qualified than he, had direct comparison been made. Since the faculty deemed it unacceptable for Bakke to be considered more qualified, no such direct comparison was to take place. In the faculty's view, it would have undermined its affirmative

186. 438 US 265 (1978).

187. Four members of the Court voted to affirm the entire state supreme court judgment for Bakke and also forbidding the university to consider race or ethnicity in admitting students, under Title VI of the Civil Rights Act of 1964, 42 USC $\$ 2000 \mathrm{a}-3$ (1988). Four other members would have reversed the entire judgment rendered in the California Supreme Court, excluding Bakke from being admitted. Justice Powell alone found that the judgment below was half correct and half incorrect, a position that thus put him in charge of the actual outcome of the case, pursuant to an opinion in which he wrote for no one except himself. (For another rare instance of a 4-1-4 vote, in which the opinion written by the Justice who announced the judgment for the Court also received no concurring votes, see Oregon v Mitchell, 400 US $112(1970)$ (sustaining an act of Congress insofar as it set the minimum voting age for federal elections at 18 , but not sustaining it as applied to eligibility to vote in state or local elections).) (Oregon $v$ Mitchell is separately notable for another reason; it is the only Supreme Court case since 1936 holding an act of Congress unconstitutional for lack of substantive constitutional enacting power, which has not yet been overruled by some other case.)

188. Bakke's science grade-point average ("GPA") was 3.44 and his overall GPA was 3.46. For 1973, the average science GPA of 16 other students was 2.62 and their overall GPA average was 2.88; for 1974, the second year of Bakke's application, the science and overall GPA average of the new group of 16 was even lower, respectively, 2.42 and 2.62. The disparities in the four categories of MCAT scores were still more dramatic: on the verbal component of the MCAT, Bakke was in the 96th percentile, the average for the 16 was in the 46th (1973) and 34th (1974); on the quantitative component, Bakke was in the 94th percentile, the average of the group was in the 24th (1973) and 30th (1974); on the science component, Bakke was in the 97th percentile, the average of the group was in the 35th (1973) and 37th (1974). Bakke did least well on the general information component of the MCAT, placing in the 72nd percentile. But the average of the group was, in respect to the same general information component of the same MCAT each year far below that (the 33rd percentile in 1973, the 18th percentile for 1974). These figures are all taken from a table presented in the Powell opinion in the case. 438 US at $277 \mathrm{n} 7$. 
action plan for Bakke to have been evaluated on the same terms with the other thirty-two students.

Four Justices concluded that this scheme violated Bakke's federal statutory right to equal consideration without regard to race, a statutory right applicable to admission to any program funded in whole in or in part by federal funds. ${ }^{189}$ The fifth, critical, vote was cast by Justice Powell. Unlike the other four Justices, however, Powell rested his decision squarely on the fourteenth amendment and not on the act of Congress alone. Noting that the fourteenth amendment applied directly to the Davis medical school (a state institution), Powell found none of the university's explanations satisfactory to justify its separate racial dual-track admissions practices as against the constitutional guarantee of equal protection of the laws. Accordingly, on that fourteenth amendment basis, he concurred with the four Justices who affirmed the judgment Bakke had received in the California Supreme Court. Allan Bakke's own overall comparative qualifications could not be dismissed by a racially closed system that put so substantial an admissions premium on not being white. The fourteenth amendment would not countenance closed racial reserves. ${ }^{190}$

Even so, in Justice Powell's view, to the extent that the medical school faculty's policy on admissions might rest on a good faith judgment of a professional sort, reflecting the same kind of academic judgment pursuant to which a faculty member might determine how most usefully to address a given subject, or what line of attack to take on a research project, or even which textbook to use, then some judicial deference might, on that ground, be due. In elaborating on his suggestion, Justice Powell's usage of "academic freedom" in the Bakke case was not at all strained; in fact, it was consistent with the Court's own prior usages of academic freedom. ${ }^{191}$ And he developed his point both strongly and well.

Concretely, Justice Powell suggested, if the ethnicity (or the race) of candidates for admission were in the faculty's professional opinion relevant

189. USC $\S \S 2000 \mathrm{a}-3$. (The Act generally forbids racial discrimination in programs assisted by federal funds.)

190. All applicants were eligible for eighty-four places within the regular admissions process under the Davis plan. Assuming, however, one were unsuccessful within that nondiscriminatory pool of applicants, one might nonetheless be eligible for any of sixteen set-aside places, but only if one qualified by a specified racial trait. Within the latter (racially restricted) pool, one would then be compared only with others likewise eligible and not with persons like Bakke. The comparative qualifications of applicants like Bakke would matter only if, once the special, racially restricted process of admission were concluded, one or more of the sixteen places had still not been filled (because too few minimally qualified persons had been within that pool in a given year). Then the other, left-out applicants (such as Bakke) might have some possible second chance. In Powell's view, this racially exclusionary admissions track could not be justified insofar as it discounted Bakke's qualifications down to zero vis-á-vis those considered within that track, though Powell did not hold that race could play no role at all. In the latter respect, he differed from the four Justices who ruled strictly on the basis of Title VI. His reasons for differing, bearing on academic freedom as they do, are provided in the text. See notes 195-99 and accompanying text.

191. The phrase is employed three times in the Powell opinion; the most relevant discussion appears at 438 US at $311-15$, citing and relying on Sweezy and Keyishian as the judicial precedents most forcefully on point. 
simply in the same manner as, say, their place of residence or their difference in undergraduate academic major-as attributes relevant to consider in the dehomogenization of what would otherwise constitute an unduly "look-alike, think-alike" cohort of first-year medical students-its consideration might not be excluded from the admissions process. Indeed, in Powell's view, its unique exclusion as having no constitutionally permissible relevance for academic admission would unnecessarily frustrate a good faith professional resolve to construct a learning, teaching, and research environment in which useful Lehrfreiheit and Lernfreiheit are expected to occur. ${ }^{192}$ Finding no absolute fourteenth amendment requirement for its nonconsideration for any purpose whatever, Powell voted to reverse that portion of the state supreme court's judgment that held that race must be ignored by any public or publicly supported university. Because, on the other hand, Bakke never received any consideration in respect to his comparative attributes, talents, skills, and background vis-á-vis those who were favored by the Davis racial set-aside plan, Justice Powell also voted to affirm that part of the judgment holding that Bakke had been unfairly excluded from such opportunity for comparative consideration. ${ }^{193}$ A proper program "treats each applicant as an individual," consistent with the equal protection clause, Powell insisted, even when it allows proper institutional academic freedom judgments to be given breathing room on their own account:

[An integrated program] treats each applicant as an individual in the admissions process. [Within such an integrated program, t] he applicant who loses out on the last available seat to another candidate receiving a "plus" on the basis of ethnic background will not have been foreclosed from all consideration for that seat simply because he was not the right color or had the wrong surname. It would mean only that his combined qualifications, which may have included similar nonobjective factors, did not outweigh those of the other applicant. His qualifications would have been weighed fairly and competitively, and he would have no basis to complain of unequal treatment under the Fourteenth Amendment. ${ }^{194}$

192. The argument is similar to (but more carefully developed than) that submitted by the AAUP in its amicus brief in the case, which is summarized as follows:

Many institutions of higher education, especially graduate and professional schools, receive more applications from candidates who are qualified, i.e., able to successfully complete the course of study, than the institution can admit. [Under these circumstances] an institution may validly conclude that the quality of the educational experience for all students is enhanced by considering as one factor in the admission process the racial diversity of the class selected. Accordingly, the AAUP will suggest that a faculty, in exercising its experienced judgment, may identify a nontrivial number of qualified minority students for admission to assure the optimal educational experience for the entire class selected.

AAUP's Brief as Amicus Curiae at 2-3, Regents of the University of Califormia $v$ Bakke, 438 US 265 (1978) (No 76-811).

193. Since, moreover, the university was unable to show that Bakke would have failed of admission even had he not been disqualified from comparison with all sixteen of the favored students both in 1973 and in 1974, pursuant to a proper integrated admissions program (which in Powell's view the Davis plan clearly was not), the state court judgment enjoining the school from refusing to enroll him was entirely proper in Justice Powell's view of the case. Accordingly, he voted to affirm this part of what the state supreme court had done. In brief, Bakke prevailed individually and the plan was enjoined.

194. Bakke, 438 US at 318 . 
That the point was a serious point, and not a specious or lightly conceived suggestion, was attested by the strong footnote he added:

The denial to respondent of this right to individualized consideration without regard to his race is the principal evil of petitioner's special admissions program. Nowhere in the opinion of [the four justices voting to sustain the program as it was] is this denial even addressed. ${ }^{195}$

Powell's use of "academic freedom" in Bakke, and his quotation of the dictum by Justice Frankfurter from the Sweezy case, ${ }^{196}$ represent no departure from the usages of academic freedom we have examined. When Powell writes of academic freedom as "long ... viewed as a special concern of the First Amendment," 197 his emphasis remains constant at all times. To gain purchase through the first amendment, the decision in any academic freedom case, whether individual or institutional, must still rest-as Frankfurter noted-on academic and not on some other grounds. It is all the same, moreover, whether the decision pertains to "who may be admitted to study" rather than to "who may teach," or "what may be taught," or "how."

So, for instance, suppose the selection of a given textbook were made by a given teacher or university professor because of a desire to befriend the particular publisher whose text one concedes to be poorer than that provided by other publishers, but whom one nonetheless felt a passionate desire to befriend. ${ }^{198}$ This is not a selection made on academic grounds. Accordingly, it should receive no first amendment academic freedom deference. Rather, one will need a reason of a different sort to defend a given textbook selection ${ }^{199}$ on academic freedom grounds, for example, that one believes the text is superior in some respect over alternative choices (whether or not others agree), or that its presentation is more lucid than that of alternative books (again, whether or not others agree), or, though not necessarily "better" in either of these respects abstractly, its perspective is more illuminating and best fits one's design for the course. Implicitly, Powell is saying all the same things in Bakke. He voted to reverse that part of the state court judgment disallowing any consideration of race in state university admissions practices; he did so on limited first amendment, academic freedom grounds. In limiting the decision, and in tightly circumscribing the university's procedures, he also sought to take due account of Bakke's equal

195. Id at $318 \mathrm{n} 52$.

196. "It is the business of a university to provide that atmosphere which is most conducive to speculation, experiment and creation. It is an atmosphere in which there prevail "the four essential freedoms" of a university-to determine for itself on academic grounds who may teach, what may be taught, how it shall be taught, and who may be admitted to study.' "Id at 312, quoting Sweezy, 354 US at 263 (emphasis added) (see note 101 and accompanying text).

197. Bakke, 438 US at 312 .

198. Perhaps because the publisher had opposed the war in Vietnam and the faculty, or a majority of the faculty, also opposed the war in Vietnam. Perhaps because the publisher had contributed money to a prolife organization or, conversely, to Planned Parenthood, and, again, the faculty also favored that social cause. Perhaps because the author is one's nephew-or niece. The range of nonprofessional (and also of unprofessional) reasons is nearly inexhaustible.

199. -Whether the defense (that is, the explanation) one means to provide is to the institution, to one's students, or, indeed, to the author or publisher of an alternative book. 
protection claims. Whether one thinks the opinion ultimately correct or not, the Powell opinion in Bakke remains to this day one of the most well-disposed treatments of "academic freedom" one can find in the cases that have adverted to that freedom in the Supreme Court.

\section{C. $(1979-1989)$}

In the first of the dozen cases reporting a usage of "academic freedom" in the most recent decade of Supreme Court adjudications, Cannon v. University of Chicago, ${ }^{200}$ the reference to academic freedom also appears in an opinion by Justice Powell. In marked contrast to Bakke, however, Cannon presented no constitutional issue. Rather, the case turned on differences of attitude toward academic freedom in matters of statutory construction and the extent to which concerns for academic freedom may influence the interpretation of a law.

In enacting Title IX of the Education Amendments of 1972, Congress provided that no person could on the basis of sex be "subjected to discrimination under any education program or activity receiving Federal financial assistance."201 The act provided expressly for agency enforcement of this provision. It did not, however, create private causes of action. Nonetheless, a majority of the Court held that such actions, though not given explicit congressional authorization, would be deemed authorized by Title IX. It was on this point that the case had gone to the Supreme Court.

In dissent, Justice White took issue with the majority. In his view, Congress had deliberately chosen not to provide for such private suits but only to require that recipient institutions answer to the appropriate disbursing agency. ${ }^{202}$ Justices Blackmun and Powell joined in Justice White's dissent. Justice Powell, however, wrote an additional thirty-page dissent to underscore the extent of his disagreement with the majority's view, and his dissent expressed concern for academic freedom. ${ }^{203}$ In Powell's view, insofar as universities would now need not only to satisfy government agencies of their compliance with the act (as Congress had intended) but would need also to take care not to invite private suits, they would be under duress to alter standards, not because the standards were inappropriate, but simply in order to forestall such suits. To be sure, Powell did not doubt Congress's power to authorize such suits. However, absent a clear expression from Congress, the Court itself ought not "revise the balance of interests struck by the legislation."'204 To do so was to ignore the costs to academic freedom, for example, by hindering a university's ability to set academic standards in good professional faith, uncompromised by an additional anxiety of threatening suits. ${ }^{205}$

200. 441 US 677 (1979).

201. 20 USC § 1681 (a) (1988); see generally 20 USC $\S \S 1681$ to 1683 (1988).

202. Cannon, 441 US at 718 (White dissenting).

203. Id at 730 (Powell dissenting).

204. Id at $748 \mathrm{n} 19$.

205. May fear of private suits adversely affect one's decisions on the merits of things? Justice Stevens briefly considered and dismissed this concern as "speculation." Id at 709. Compare the 
Powell's concern for academic freedom in Cannon was of a piece with Justice Frankfurter's opinion in Sweezy v. New Hampshire. ${ }^{206}$ An individual teacher (as in Sweezy) or an institution (as in Cannon) can be substantially compromised at the margin of professional judgment when the alternative is to risk an encounter with a very high-voltage fence. If one's sole concern is that the fence stimulate a suitably strong aversive reflex, of course, one will not mind; indeed, one may be inclined to say, "the higher the voltage, the better this fence!" In Powell's view, this was pretty much the majority's approach in Cannon. ${ }^{207}$ But, for Powell, it is just this reasoning that also made the decision even more obviously incorrect. The higher the voltage, the greater the fear and so the greater the loss of the margin of the useful field now newly abandoned nearby the fence. The majority of the Court might see that loss as of little consequence. But so to suppose, and so to decide the case absent a clear congressional requirement to do so was in a larger sense seriously inconsistent with the Court's own prior decisions since 1957. Unavailing in Cannon, Powell's opinion was nevertheless well within the tradition Frankfurter marked out beginning with Sweezy, and influential with the Court in cases such as Keyishian and Bakke as well.

In contrast with Cannon, the issue in Regents of University of Michigan $v$. Ewing ${ }^{208}$ concerned the substantive due process claim of a student dropped in his sixth year from the University of Michigan Medical School and refused readmission on academic grounds after failing a major written examinationa two-day test administered by the National Board of Medical Examiners, successful completion of which was required to receive his degree. The student, Scott Ewing, did not dispute the requirement of the examination nor the requirement of its successful completion to secure a degree. He did not deny that he had failed to achieve the university's minimum passing score for the test. But he observed that others who had failed the same examination

general reflections of Judge Learned Hand: "After now some dozen years of experience I must say that .. I I should dread a lawsuit beyond almost anything else short of sickness and death." Learned Hand, 3 Lectures on Legal Topics, Association of the Bar of the City of New York 106 (Macmillan, 1926). Academics, like others, may do a great deal to avoid sickness or death, nor are they known to be braver than Learned Hand in fearing a lawsuit.

206. Indeed, in his discussion of academic freedom, Powell explicitly drew from and relied upon Frankfurter's opinion in Sweezy. 441 US at 747-48, citing Frankfurter in Sweezy, 354 US 234; see also text accompanying notes 94-101

207. Ten years after Cannon, in University of Pennsylvania v EEOC, $111 \mathrm{~S} \mathrm{Ct} 577$ (1990), the Court also rejected any claim of qualified confidentiality of tenure review files under subpoena demand of the EEOC. The AAUP filed an amicus brief endorsing a qualified privilege, akin to that generally recognized when grand juries subpoena a reporter's notes, and relying on Sweezy. AAUP's Brief as Amicus Curiae, University of Pennsylvania v EEOC, $110 \mathrm{~S}$ C 577(1990) (No 88-493). Two federal courts of appeal had agreed (although two others had not), and each had directed federal district courts to review EEOC subpoenas of academic tenure review files of confidential peer review materials by standards of scrutiny derived from Frankfurter's opinion in Sweezy. Purporting to distinguish Sweezy on the basis that the inquiry in that case went to the content of teaching, whereas here it went to the determination of professional qualification (though why that difference should be thought to matter is nowhere explained), the Court rejected the claim. University of Pennsyluania, 110 $\mathrm{S} \mathrm{Cl}$ at 585-87. The tenor and decision in University of Pennsylvania are more at odds with Sweezy than any other single case to come from the Supreme Court during the past thirty-five years.

208. 474 US 214 (1985). 
had been permitted to retake the examination rather than being dropped. Indeed, it appeared that he was the first student ever to be dropped rather than being permitted to try again. To be sure, his scores were the lowest in the history of the program, and the medical school had provided a hearing that reviewed his whole academic career and not simply his examination score. (From any point of view, therefore, procedural due process was easily satisfied in the medical school's handling of his case. ${ }^{209}$ ) But in Ewing's view-and in the view of the federal court of appeals that reviewed the trial record of the case in the district court-there was nothing in the record that provided any reasonable basis for the apparent harshness of discontinuing Ewing's medical school career. On that basis, the court of appeals had reversed the district court's dismissal of his case. ${ }^{210}$

The Supreme Court unanimously disagreed with this disposition. In respect to substantive academic judgments within universities, the Court declared:

When judges are asked to review the substance of a genuinely academic decision ... they may not override it unless it is such a substantial departure from accepted academic norms as to demonstrate that the person or committee responsible did not actually exercise professional judgment .... Added to our concern for lack of standards (there are none obviously provided by the Constitution or elsewhere according to which judges or juries can say what norms of academic competence are suitable or unsuitable for any university as such) is a reluctance to trench on the prerogatives of . . . educational institutions and our responsibility to safeguard their academic freedom, "a special concern of the First Amendment."211

Only where the faculty can be shown to have abdicated its responsibility to make judgments on academic grounds (that is, only when it does "not actually exercise professional judgment") does it forfeit the protection the first amendment provides. ${ }^{212}$ Ewing, with Keyishian, Frankfurter's opinion in

209. Whether the school might have been faulted had it not provided such a hearing incident to a student's dismissal for academic (rather than disciplinary) reasons was thus not at issue in Ewing. In all likelihood, however, no particular kind of intramural review of the kind provided Scott Ewing would be held to be required as a matter of constitutional right. (In an earlier case, the Supreme Court expressed substantial reservations on the point. See Board of Curators, University of Missouriv Horowitz, 435 US 78 (1978).) Where, in contrast, a student's standing in a public university is put in jeopardy because of an infraction of the rules (such as stealing, harassment, drinking, plagiarism, or campus disruption), predecisional intramural procedural due process is much more likely to be deemed constitutionally required. See, for example, Dixon v Alabama State Board of Educ, 294 F2d 150 (5th Cir 1961).

210. In conventional 14th amendment constitutional terms, Ewing's complaint was one of substantive due process, that is, the alleged lack of any sufficient substantive reason for depriving him of his "property" interest in his status as a student in good standing in a state university. Of course, the case may also be seen as one affecting a student's substantive academic freedom in the same sense as discussed in Baggett v Bullitt, 377 US 360, that is, the continuing freedom of one within the university to continue to study, to learn, and to interact with the faculty, assuming satisfactory work as determined in good professional faith. See, for example, 1967 Statement at 142: Appendix C, 53 L \& Contemp Probs at 412 (cited in note 7) ("Student performance should be evaluated solely on an academic basis, not on opinions or conduct in matters unrelated to academic standards.").

211. Ewing, 474 US at 225-26. The standard adopted and applied by the Court in Euing was put forward in virtually the same terms in the amicus brief of the AAUP. AAUP's Brief as Amicus Curiae, Regents of Eniversity of Michigan v Ezing, 474 US 214 (1985) (No 84-1273).

212. See also Justice Powell's strongly supportive view adopting essentially the same standard on matters of evaluating persons for appointment or tenure, in Hishon "King 8 Spalding, 467 US 69, 80 
Sweezy, and Justice Powell's opinion in Bakke, is among the Court's strongest first amendment-based decisions articulating the meaning of academic freedom in higher education.

With two exceptions, both addressed to the scope of academic freedom in public secondary education, the balance of decisions reporting a usage of "academic freedom" in the Supreme Court during this most recent decade are but slight refinements on earlier themes.

Such a refinement is furnished by Widmar $v$. Vincent, ${ }^{213}$ decided by the Court in 1981. Widmar provided a reprise on Healy $v$. James ${ }^{214}$ and raised anew the scope of constitutional protection afforded student groups on public university campuses. Unlike Healy, however, Widmar did not involve a refusal to "recognize" a particular student organization, such as a refusal to permit it to meet on campus, post notices, solicit members, and have the same oncampus privileges as any other student organization could claim. At issue, rather, was a board of curators rule forbidding a particular use of university buildings or university grounds regardless of what group might be involved. The use of such buildings or grounds for "religious worship or religious teaching" was forbidden, and the board of curators believed this restriction was required by a clause of the Missouri Constitution. ${ }^{215}$ Cornerstone, a student organization of evangelical Christian students from various denominational backgrounds at the University of Missouri at Kansas City, found itself altogether frustrated by this use restriction. Effectively, the restriction denied them any use of university buildings for the very sort of meetings and activities they were most committed to provide as a group. ${ }^{216}$ Lacking any other recourse against the rule, Clark Vincent and other student

n4 (1983) ("Courts of Appeals generally have acknowledged that respect for academic freedom requires some deference to the judgment of schools and universities as to the qualifications of professors, particularly those considered for tenured positions."). See generally Judith Jarvis Thomson, Ideology and Faculty Selection, 53 L \& Contemp Probs 155 (Summer 1990).

213. 454 US $263(1981)$.

214. 408 US 169 .

215. Widmar, 454 US at 263. The Missouri constitutional provision was worded similarly to, but somewhat more far-reachingly than, the provision in the first amendment that forbids any act of Congress "respecting an establishment of religion." Mo Const, Art I $\$ \S 6,7$; Art IX $\$ 8$. In McCollum v Board of Educ., 333 US 203 (1948), the Supreme Court had held that this clause in the first amendment was equally applicable to the states through the 14 th amendment and was violated by a religious "released-time program" in a public school, which co-ordinated religious instruction by religious teachers using school classrooms during the regular school hours. (The fact that students were nominally not compelled to attend, but might instead remain in a regular classroom while the released-time religious classes met, was held to be of insufficient significance.) Compare Zorach $v$ Clauson, 343 US 306 (1952) (similar plan sustained, five-to-four, when the released students met religious classes off school premises, even if those not opting into the program were kept in a study hall at the public school). In llidmar, even supposing that the 14 th amendment might not bar a state university from permitting sectarian religious activities on campus when sponsored by a student group permitted use of campus facilities on the same terms as every other student group, the board of curators believed that the Missouri Constitution nonetheless forbade such use of public facilities. 454 US at 265.

216. "A typical Cornerstone meeting included prayer, hymns, Bible commentary, and discussion of religious views and experiences." Id at $265 \mathrm{n} 2$. The meetings were also generally open to other students to attend, part of the purpose being to win adherents to Cornerstone's religious commitments. Id. 
members of Cornerstone sued to enjoin Gary Widmar (the dean of students) and the university's board of curators from enforcing the rule against them. In the Supreme Court, as well as in the court of appeals, their claim prevailed on first amendment grounds. Justice Powell, writing for the Court in Widmar, said that even supposing that Cornerstone sought "to win . . converts" 217 in its meetings on campus (as well as to realize its members' shared religious enthusiasms), the point provided no sensible distinction from what the Court had already decided in Healy and Tinker. Common rules of time, place, and manner governing on-campus facilities, consistent with standards reviewed in Healy, would apply to Cornerstone as to any other on-campus group, ${ }^{218}$ but not a content-censoring restriction, which, in the Court's view, the curator's rule, even if adopted under requirement of the state Constitution, obviously was. Widmar, moreover, is not reasoned on the basis of the free exercise clause but on more generalized freedom of speech principles. Widmar is thus of a piece with the strong holding in Tinker, Powell's holding in Healy, and Justice Douglas' opinion in Jones v. Board of Education. 219

A concurring opinion in Widmar by Justice Stevens ${ }^{220}$ makes a point not in disagreement with Powell's majority opinion, but qualifying it in a manner anticipating his own applied usage of "academic freedom" in Ewing. Stevens expressly referred to "academic freedom" to disallow intrusive judicial review of institutional procedures for handling disputes in allocating university space. In Stevens' view, the first amendment may shelter on-campus free speech and meeting rights of students at public institutions. Even so, he insisted, where such groups seek use of facilities, the first amendment does not require suspension of institutional opinion respecting their relative academic worthiness-at least in mediating competing demands, if not in judging their general "right" to be on campus. Rather, the first amendment specifically protects academic value judgments reflected in institutional mechanisms established to determine priorities of use where not all requests can simultaneously be granted. In Stevens' view, institutional discretion of this sort is not different in kind than the sort Powell embraced for the Court in the Bakke case. It is correspondingly entitled to a strong measure of academic freedom respect in the courts.

Stevens offered an example: suppose one group requests use of a room to show Disney films, and another requests its use to present Hamlet. Must the conflict be resolved by, say, flipping a coin or by some other equally

217. Id at $269-70 \mathrm{n} 6$.

218. See id at 276. An additional cautionary note is sounded in regard to student activities otherwise protected by the first amendment when conducted in ways that "substantially interfere with the opportunity of other students to obtain an education." Id at 277. But allowable regulations of this sort are themselves merely an example of uniform rules of time, place, and manner (for example, rules suitably drawn to avoid harassment of others by regulating the time, place, and manner of holding one's meetings or otherwise seeking to win support for one's general views), and not a ban based on the unwelcomeness of certain ideas.

219. Jones, 397 US 31. See also 1967 Statement at Part IV; Appendix C, 53 L \& Contemp Probs at 413-15 (cited in noce 7).

220. 454 US 277, 278-80. 
impersonal mechanism, lest some other basis be thought to infringe on the first amendment claims of both groups? Stevens suggests not. If the decision is to prefer Disney to Hamlet (Stevens uses this contrast deliberately), and for the reason that Hamlet is already well covered in standard courses whereas "the genius of Walt Disney" has not previously been given any airing at all, then, though the decision is made on this basis of comparative academic worth rather than some other more "neutral" basis (for example, as to who applied first), the first amendment shifts its center of gravity to protect the decision from intrusive judicial review. ${ }^{221}$ In this respect, the usage of "academic freedom" reflected in Stevens' concurrence in Widmar is of a piece with the position he reflected in Ewing as well. ${ }^{222}$

In a case arising between Widmar and Ewing, involving faculty rather than students, ${ }^{223}$ a different usage of "academic freedom" appears. A Minnesota law imposed an obligation on the state board governing the state community college system to "meet and confer" from time to time with faculty on matters of educational policy. It imposed a similar obligation equally on the administration of each college. At the same time, however, the same law also forbade either the state board or any community college administration to permit any faculty member to appear in such meetings other than as a designee of whatever professional association (that is, union) had gained exclusive representation rights for collective bargaining purposes, even though these meetings were in no sense collective bargaining sessions but were meant to address other kinds of issues. The effect of the law, combined with the practice of the faculty union, was altogether to exclude nonunion

221. See id at 278-79 (Stevens concurring) ("Judgments of this kind should be made by academicians, not by federal judges ...."), citing Sweezy, 354 US at 261 (Frankfurter concurring), and Bakke, 438 US at 312 , and repeating the quotation that "[a]cademic freedom, though not a specifically enumerated constitutional right, long has been viewed as a special concern of the First Amendment." 454 US at 279.

222. Yet despite Justice Stevens' insightful and supportive endorsement of academic freedom in this usage, that is, protecting such allocative decisions from judicial review, one may doubt that the analogy to Bakke or Ewing properly holds in cases of this sort. Why? Because in respect to these groups, each involving no institutional endorsement or sponsorship (Widmar and Cornerstone is an example), their presence on campus owes nothing to judgments of academic connection: accordingly, neither should their requests about times and places to meet. Consider a case similar to that which Justice Stevens proposed. Suppose it is not a case where a student group rehearsal of Hamlet (for its own amusement) competes for reservation of an unused room with a student group request to reserve the same room to view Disney films (for its own amusement). Rather, a reservation request by the Federalist Society is followed later the same day by a competing request for the same room at the same time by the Student Gay-Lesbian Alliance. On Justice Stevens' view, the latter request, though second-arriving, may be given priority if done on the basis of an academic (rather than a political) judgment. What would such a judgment consist of? Presumably it might be merely a judgment of just the kind Stevens used: federalism perspectives are already well covered in the standard curriculum, whereas gay-lesbian perspectives have not been equally featured. From the decision-maker's position, this may seem reasonable enough. From the perspective of the rejected group, however, it seems supererogatory (as well as suspect). Losing the room on such grounds to some university event or university sponsored activity is one thing. Losing it to another group no different from itself (in that it is equally an unsponsored group and, like this group, merely pursuing its own agenda on campus) on some notion of superior academic timeliness about the other group's agenda, is another. It puts the university's thumb on a scale where arguably it does not belong at all.

223. Minnesota State Board for Community Colleges v Knight, 465 US 271 (1984). 
faculty members who wished also to be heard on matters of educational policy (for example, what should be taught). Such faculty might still attempt to communicate their views informally - by writing personal letters ${ }^{224}$ - but they were barred from speaking in the only formally required regular meetings. Several of the adversely affected faculty sued to enjoin this restriction on first amendment grounds. The federal district court held that this restriction, running as it did to these overall "meet and confer" meetings and not more narrowly (for example, to specific collective bargaining negotiations alone), unfairly curtailed the first amendment academic freedom of those faculty members not electing to be union members to be heard on matters of equal professional concern to them as academics. ${ }^{225}$ However, the Supreme Court reversed, albeit in a closely divided vote.

Writing for the Court over a dissent by Justices Powell, Stevens, and Brennan, and a partial dissent by Justice Marshall, Justice O'Connor put the decision reversing the lower court principally on the basis that, had there been no state law requiring such meet and confer sessions, plaintiffs could not have compelled the holding of such meetings. This being so, in her view, they had no better basis for complaint here. Insofar as the state wished to provide for such meetings by way of an extended opportunity for the union to communicate its concerns on general matters (leaving others to the informal recourse they already enjoyed), there could be no sensible constitutional objection. Going beyond the needs of the immediate case, however, O'Connor also added the following passages, at once both clear and bleak in rejecting an entire category of professional academic freedom first amendment claims:

To be sure, there is a strong, if not universal or uniform, tradition of faculty participation in school governance, and there are numerous policy arguments to support such participation. See American Association of Higher Education-National Education Association, Faculty Participation in Academic Governance (1967); Brief for American Association of University Professors as Amicus Curiae 3-10. But this Court has never recognized a constitutional right of faculty to participate in policymaking in academic institutions. . . . Even assuming that speech rights guaranteed by the First Amendment take on a special meaning in an academic setting ... there is no constitutional right to participate in academic governance. ${ }^{226}$

Though concurring in the particular judgment in the case, Justice Marshall expressly disassociated himself from this part of the Court's majority opinion. ${ }^{227}$ Writing separately in dissent, Brennan explained for himself,

224. Id at $277 \mathrm{n} 4$.

225. Knight v Minnesota Community College Faculty Ass n, 571 F Supp 1, 7-12 (D Minn 1982). In an amicus brief, the AAUP agreed with this view. AAUP's Brief as Amicus Curiae, Minnesota State Board for Community Colleges v Knight, 465 US 271 (1984) (Nos 82-898 and 82-977). See also Madison Joint School Dist. $v$ Wisconsin Employment Relations Comm in, 429 US 167 (1976) (holding that a state law effectively forbidding a nonunion teacher to address an elected school board in a general meeting of the school board open to the public, without the union's permission to do so, violated the silenced teacher's personal first amendment rights; AAUP amicus brief supporting the claim on first amendment-academic freedom grounds).

226. Knight, 465 US at 287-88.

227. Id at 293 (Marshall concurring) ("Such participation is . . essential if our academic institutions are to fulfill their dual responsibility to advance the frontiers of knowledge through 
"why, irrespective of other grounds, principles of academic freedom require affirmance of the District Court's holding," 228 namely that in his view:

[The f]irst amendment freedom to explore novel or controversial ideas in the classroom is closely linked to the freedom of faculty members to express their views to the administration concerning matters of academic governance. . . . The freedom to teach without inhibition may be jeopardized just as gravely by a restriction on the faculty's ability to speak out on such matters as by the more direct restrictions struck down in Keyishian and in Epperson. In my view, therefore, a direct prohibition of some identified faculty group from submitting their views concerning academic policy questions for consideration by college administrators would plainly violate the principles of academic freedom enshrined in the First Amendment. ${ }^{229}$

An additional dissent separately added by Stevens (and joined by Justices Brennan and Powell) strongly endorsed Brennan's perspective. As a consequence, the contrast within the Supreme Court in Knight could not have been more pronounced. The majority saw the case as simply a matter of meetings that need not have been provided for in any event, and insofar as they were provided they furnished an opportunity for substantial faculty representation albeit limited to designees of the faculty's own professional group. The dissent viewed the same statute, however, as working a serious and unwarranted restriction on some faculty members' opportunities to be heard on matters of academic substance as part and parcel of their own academic freedom, disadvantaging them solely on the basis of their individual decisions not to become union members although still obliged to pay full dues. Unaffected by the Court's decision in Knight are such meetings as are required to be held for general public purposes. ${ }^{230}$ Unaffected, too, may be the assurance that faculty submitting professional concerns through correspondence and other channels may still claim a strong measure of first amendment academic freedom protection. Still, the majority's dicta as well as its holding in Knight significantly diminish a university faculty because of the distinctly managerial view of academic institutions to which the O'Connor opinion strongly yields. Among decisions of the past decade, Knight is one of two $^{231}$ that have leaned against the course Justice Frankfurter originally set for the Court in Sweezy, three decades ago.

Knight is nonetheless also a useful transitional case in moving to the last three decisions completing this unhurried review of usages of academic freedom and the first amendment in the Supreme Court. What makes it so is the character of the colleges engaged in the litigation. Knight concerned twoyear community colleges, which are not quite four-year public baccalaureate degree institutions nor advanced degree research universities on the one hand, nor public primary or secondary schools on the other. We have not

unfettered inquiry and debate ... and to produce a citizenry willing and able to involve itself in the governance of the polity. ....) (citation omitted).

228. Id at 295 (Brennan dissenting).

229. Id at 296-97.

230. See Madison Joint School Dist., 429 US 167.

231. The other is limiversity of Pennsylvania, $110 \mathrm{~S} \mathrm{Ci} 577$. 
hitherto noticed a great deal turning on such matters, ${ }^{232}$ but the distinction becomes more important as our review nears its end. ${ }^{233}$

Some of "the functions of educational institutions in our national life" to which Justice Frankfurter made reference in Wieman $v$. Updegraff ${ }^{234}$ are of a sort more easily associated with universities than with public schools, for example, functions of critical scholarship and research. The tasks of primary and secondary schools are at once much more mixed and substantially more instrumental than those of colleges or universities. The age of the student, the requirement of attendance, the standardization of teacher credentialing, the structured inculcation of basic skills, and other factors describe a very different milieu. The importance of these schools is not diminished by these observations. Far from it. ${ }^{235}$ They nonetheless serve in a cautionary fashion, distancing the environment of public schools from universities. Academic freedom plays out somewhat differently in the milieu of primary and secondary public education. ${ }^{236}$ It is drawn in principally as a constitutional check against state tendencies to misuse powers of educational command to censor materials or instruction, but it plays out much more ambiguously and without the same breadth of reach.

An example of the difference is offered by the 1982 decision of the Supreme Court in Board of Education $v$ Pico ${ }^{237}$ The case arose after a local

232. For example, although Sweezy involved a state university (rather than a community college or a local public school), the strong statement by Frankfurter emphasized "the nature of the teacher's role" and the importance of disallowing "unwarranted inhibition upon the free spirit of teachers" (that is, it was not limited to "professors" or to those with doctorates). Moreover, several of the more significant cases were public school rather than higher education cases (for example, Adler (disqualification from public school teaching of persons with certain political affiliations), Pickering (public expression by teachers), Scopes (public school course content restrictions) and Epperson (same)).

233. See, for example, DiBona v Matthews, 220 Cal App 3d 1329, 269 Cal Rptr 882 (1990), cert denied, 59 USLW 3402 (1990) (community college administration's cancellation of drama class held to violate first amendment, suit brought by the drama instructor and an enrolled student; court rejected the comparison of community college with high schools in measuring the protected range of drama instructor's professional discretion to determine course content, locating it more closely in keeping with the fuller range of academic freedom in colleges (than in high schools) and noting: "Defendants have cited no authority - and we are aware of none-which would allow a college or university to censor instructor-selected curriculum materials because they contain 'indecent' language or deal with 'offensive' topics." Id at 1346-47, 269 Cal Rptr at 893).

234. 344 US at 197; see notes 88-92 and accompanying text.

235. Indeed, it is primary and secondary education (not universities) that was the immediate reference of the Warren Court when it noted: "In these days, it is doubtful that any child may reasonably be expected to succeed in life if he is denied the opportunity of an education." The quotation is, of course, from Brown v Board of Educ., 347 US 483, 493 (1954).

236. In West Virginia State Board of Educ. v Barnette, 319 US 624 (1943), the Supreme Court struck down a state law requiring public school children to participate in daily pledges of allegiance to the American flag. It did so on the ground that such compulsory expression of political belief under state direction was inconsistent with the broad protection afforded by the first amendment from forced recitation of political beliefs one may not share, and that even grade school children may constitutionally resist such exercises despite the ambitions of the state (including a democratic state) to inculcate patriotism by this means. Id at 634-42. Perhaps surprisingly, Justice Frankfurter dissented. Id at 646. Plainly, his views on the "functions" of public schools, and his views of the "functions" of universities, were not all the same. For a recent thoughtful review of such matters more generally, see Amy Gutmann, Democratic Education (Princeton Univ Press, 1987).

237. Board of Educ., Island Trees v Pico, 457 US 853 (1982). 
elected school board in Island Trees, New York, ordered the removal of nine specified books from all high school and junior high school libraries in the district. Suit was brought in federal district court on behalf of several students. On first amendment grounds they sought an injunction against the school board's removal decree insofar as it affected the libraries at the schools in which they were enrolled. But the constitutional basis for their suit was far from compelling. ${ }^{238}$ Some of the books were seriously controversial; their suitability for youngsters (in comparison with university students ${ }^{299}$ or community college students) was by no means obvious. Nor could it easily be argued that, even so, they might well serve to cultivate values of tolerance and a mutual appreciation of positive differences in a free democratic societythemes the Court had stressed as consistent with the proper educational function of public schools. To the contrary, the books might be thought to convey destructive images and crude, offensive stereotypes. ${ }^{240}$ To be sure, the first amendment might well not permit a general ban on the availability of such books to minors merely on that account, but no restriction on what these students could buy, read at home, or borrow from a public library was involved here. Nonetheless, the students prevailed, at least partially. On first

238. Since only students were suing (no teacher, librarian, book publisher, or author claimed ground for relief), the case shaped up quite unpromisingly, as a claim asserted by public school students to have their first amendment view of material suitable for a school library prevail in opposition to the view of the school board of the district in which they resided. Viewed this way, the case seemed weak. The district court granted summary judgment to the school board. $474 \mathrm{~F} \mathrm{Supp}$ 387 (ED NY 1979). Fortunately for the plaintiffs, however, the board had acted against recommendations of its own appointed parent-teacher book review committee in respect to seven of the nine books it ordered removed. In rejecting the committee's recommendations, moreover, the board had declined even to say why. Portions of the plurality opinion for the Supreme Court substantially relied on these facts in determining what deference was due the judgment of the school board. 457 U.S. at 874-75. Additionally, as the case proceeded in the courts, the action seeking reinstatement, or reshelving, of the books was strongly supported in amicus briefs filed on behalf of the National Education Association, the American Library Association, the Authors League of America, and P.E.N. American Center. See id at 855. So the actual array of interested parties in securing first amendment limits on school library book-removal practices by politicized school boards was in fact very substantial, putting the case in a stronger light.

239. A critical first amendment distinction of this kind is made in the dissent illustrating the constitutional difference (of role and function) members of the Court tend to attribute to universities as distinct from public schools. See id at 915 (Rehnquist dissenting) (expressly distinguishing universities from public schools in just this way). See also note 236 (views of Justice Frankfurter on the same point).

240. By way of example, Justice Powell provided seven pages of excerpts from some of the books as an Appendix to his dissent, $457 \mathrm{US}$ at 897-904. They included such passages as these: "There are white men who will pay you to fuck their wives. They approach you and say, 'How would you like to fuck a white woman?' 'What is this?' you ask. 'On the up-and-up,' he assures you. 'It's all right. She's my wife. She needs black rod, is all. She has to have it. It's like a medicine or drug to her. I'll pay you.", Eldridge Cleaver, Soul on Ice (quoted at id at 897); "What do you think goes on in the wagon at night: Are the drivers on their knees fucking their mothers? . . . 'Who else would do anything like that but a mother-fucking Zhid?' . . . 'No more noise out of you or I'll shoot your Jew cock off.'

'You cocksucker Zhid, I ought to make you lick it up off the floor.' " Bernard Malmud, The Fixer (id at 898-99); "'I wonder if sex without acid could be so exciting, so wonderful, so indescribable.' ... Another day, another blow job . . . . If I don't give Big Ass a blow he'll cut off my supply." Anonymous, Go Ask Alice (id at 899). 
amendment grounds, albeit on a close five-to-four vote, ${ }^{241}$ the Court granted them an opportunity to put the school board's actions on trial in federal district court, with a fair possibility of getting some of the books put back.

The success of the case essentially turned on evidence in the record that at least some of the books ${ }^{242}$ had been removed because of a desire to suppress information and perspectives reflected in these books not supportive of political and social doctrines the board members and their most active constituents sought personally to advance through their control of public schools. Removal of the books from all of the district's public school libraries may have been ordered, in short, " "not in the interests of the children's wellbeing' " but rather for the purpose of establishing those political views " 'as the correct and orthodox ones for all purposes in the particular community.","243 The strategy was to "contract the spectrum of available knowledge" 244 by banning books presenting views other than those the board members wanted to prevail in the larger community. ${ }^{245}$ There being evidence of this design in the record of the case, then, as the court of appeals had held, the plaintiffs " "should have ... been offered an opportunity to persuade a

241. The case utterly divided the Supreme Court, producing seven separate opinions, and a majority on no opinion. Id at 899 . See the description provided in the Supreme Court Reporter's remarkable headnote to the case:

BRENNAN, J., announced the judgment of the Court and delivered an opinion, in which MARSHALL and STEVENS, JJ., joined and in all but Part II-A(1) of which BLACKMUN, J., joined. BLACKMUN, J., filed an opinion concurring in part and concurring in the judgment, post, p. 875. WHITE, J., filed an opinion concurring in the judgment, post, p. 883. BURGER, C.J., filed a dissenting opinion, in which POWELL, REHNQUIST, and O'CONNOR, IJ., joined, post, p. 885. POWELL, J., filed a dissenting opinion, post, p. 893. REHNQUIST, J., filed a dissenting opinion, in which BURGER, C.J., and POWELL, J., joined, post, p. 904. O'CONNOR, J., filed a dissenting opinion, post, p. 921.

Id at 854-55.

242. Among the nine books targeted for removal from the high school library were Kurt Vonnegut, Jr.'s Slaughterhouse-Five, Desmond Morris's The Naked Ape, and Langston Hughes, ed, Best Short Stories of Negro Writers. Id at $856 \mathrm{n} 3$. All have figured prominently in pubiic school bookbanning litigation. See, for example, Parducci v Rutland, 316 F Supp 352 (MD Ala 1970) (reinstating a high school $1 \mathrm{lth}$ grade English teacher after dismissal for insubordination in refusing to discontinue use of Vonnegut's Welcome to the Monkey House). This case is especially noteworthy insofar as the federal judge, Frank Johnson, wrote explicitly that the teacher's professional interest was that of "academic freedom," as a first amendment-protected freedom, and held that the action of the school principal and school board "constituted an unwarranted invasion of her First Amendment right to academic freedom." Id at 356.

243. Pico, 457 US at $860-61$ nl6, quoting opinion of Judge Sifton, 638 F2d 404, 417 (2d Cir 1980) (reversing the grant of summary judgment in favor of the board). By way of example, the Court quoted from statements made by several board members such as this: " II am basically a conservative in my general philosophy .... I feel that it is my duty to apply my conservative principles to the decision/s]. . . in which I am involved as a board member and I have done so with regard to . . curriculum formation and content and other educational matters." "Id at 872-73 n24 (emphasis added). A deposition of another board member acknowledged that he voted to remove one of the books because of its "anti-Americanism," such as the failure of the book to omit mention that George Washington was a slaveholder. Id at 873 n25. "That [including mention that Washington did own slaves] is one example of what I would consider anti-American," the board member said. Id.

244. Id at 866, quoting Justice Douglas in Griswold $v$ Connecticut, 381 US 479, 482 (1965).

245. See discussion and examples in notes $240,243$. 
finder of fact that the ostensible justifications for [the school board's] actions ... were simply pretexts." "'246

Pico was, by any fair judgment, an important first amendment (and academic freedom ${ }^{247}$ ) decision, albeit perhaps less so for the decision it reached than for the decision it avoided. Decided on the grounds identified by the Court, it stands for an orthodox general first amendment principle, in no way peculiar to public education: public agencies, local school boards not excepted, may not attempt to "contract the spectrum of available knowledge" when the object to be served is to try to restrict freedom of information just because the information is of a kind others might draw upon to question or to dissent from the views that that public agency ${ }^{248}$ thinks it best for the public, or some subset of the public, to entertain. Understood this way, there is really nothing extraordinary here. Justice Robert Jackson put the basic relevant proposition quite well half a century ago, and probably no one has much improved upon it since:

The Fourteenth Amendment, as now applied to the States, protects the citizen against the State itself and all of its creatures-Boards of Education not excepted. These have, of course, important, delicate, and highly discretionary functions, but none that they may not perform within the limits of the Bill of Rights. That they are educating the young for citizenship is reason for scrupulous protection of Constitutional freedoms of the individual, if we are not to strangle the free mind at its source and teach youth to discount important principles of our government as mere platitudes. ${ }^{249}$

Indeed, not the worst way of testing Pico's own limited holding is to ask what one would say had the Court decided the case in favor of the school board. Were a school board to be regarded as unreviewable in designating only such books as it approved as "suitable" for public school library use, how could

246. 457 US at 860 , quoting (with approval) the approach reflected in the court of appeals, 638 F2d at 417 . Pico thus had a strong, direct link to Ewing, reviewed in the text accompanying notes 20812. Here, in contrast to Ewing, there was strong evidence that the board was not actually exercising a good faith judgment at all. Moreover, so far as there had been a review of the particular books on general grounds of educational suitability (a review that appeared to have been made in good faith), that review had reached much different conclusions as to most of the books. See note 238 .

247. And Pico is an "academic freedom" case, reaching (as it does) the conditions inside educational institutions, the contents of their libraries, student opportunity of access, and professional staff judgment in their selection and use, albeit decided on limited first amendment grounds. In Pico itself, moreover, faculty academic freedom was also implicated directly and not merely indirectly by the school board's directive ordering removal of the books, especially since the directive also forbade any curricular use of the same books. See Pico, 457 US at 858 ("As a result [of the board's actions], the nine removed books could not be assigned or suggested to students in connection with school work."). Among the plaintiffs' complaints in the case was a complaint quite the same as that which we examined originally in Baggett, 377 US at 360, that the school board action infringed on the range of the student's own educational interaction, because the restrictions on those who taught affected as well those who wished to learn. See Pico, 457 US at $862 \mathrm{n} 18$ (describing the board actions as "restrictions upon [the teachers'] ability to function as teachers in violation of principles of academic freedom.").

248. Or, rather, those politically able to dominate that agency, which must then merely stimulate competition among community groups, in turn, as to whose views shall control. Compare the opinion of Justice Jackson in Barnette, 319 US at 641: "It seems trite but necessary to say that the First Amendment to our Constitution was designed to avoid these ends by avoiding these beginnings."

249. Id at 637 . 
one reconcile that rule of law with the first amendment or with any genuine academic freedom in public schools, and what kind of rule of law would such a rule be? This is, however, roughly the alternative the majority of the Court in Pico believed it was confronted with, given evidence in the record of the assumptions the school board entertained of its prerogatives as well as how it acted on those assumptions. There is little reason to suggest that the Court was anything other than correct.

Although Pico dealt with a removal of books from public school libraries, it is strongly of a piece with cases such as Epperson v. Arkansas and Scopes v. Tennessee, though Epperson and Scopes were instances of classroom rather than library censorship. In each, political decisions were at work deliberately to "contract the spectrum of available knowledge" within the public school. In each instance, the restriction was sought in order to insulate the ideological status quo from the distress that is always at risk when academic freedom is tolerated at any level of education, whether it is applied to certain subjects, to certain books, or to certain teachers. Scopes and Epperson merely furnished clear examples. But Pico was also, as the Court properly reviewed it, essentially the same sort of restriction one step removed.

Scopes and Epperson had dealt with efforts not to ban academic access to books by modern social anti-establishmentarians such as Kurt Vonnegut or Langston Hughes, but rather to suppress teaching of Charles Darwin's workeven a century after his original field studies had taken place. And, quite remarkably, soon after Pico the Supreme Court made still another return to Charles Darwin and academic freedom in public schools. It did so in 1987, a date coincidentally marking the bicentennial of the Constitution, twenty years after Epperson, decided in 1968 . The case providing the occasion for a further review of this seemingly endless feud between science and religion is Edwards $v$. Aguillard. ${ }^{250}$ With Scopes having served as the beginning of our unhurried review, it is altogether fitting that Edwards $v$. Aguillard should itself serve as our end. ${ }^{251}$

250. 482 US 578 (1987).

251. For the sake of completeness (that is, in reporting usages of "academic freedom" in the Supreme Court), however, mention should be made of one other case in the Supreme Court adverting to academic freedom during this most recent decade, Memphis Community School Dist. $v$ Stachura, 477 US 299 (1986). Stachura was a private civil action brought in federal court by a public school teacher of life sciences after she was suspended by a local school board without a hearing (albeit with pay). The board had suspended her in hasty response to a local uproar based on inaccurate reports about two films she had used in her seventh-grade class on human growth and sexuality. Both films in fact had been provided by the local health department and approved by the high school principal; so, as it happened-unsurprisingly when due process is ignored-the teacher was suspended even while conducting her class altogether unexceptionably, that is, exactly in the manner she was authorized to do. Stachura was hastily reinstated the following fall semester albeit only after she had filed suit against the school board and its members. Though reinstatement was thus no longer at issue, she pressed forward with claims for money damages and fared quite well at trial; the jury awarded her $\$ 275,000$ in compensatory damages and $\$ 46,000$ in punitive damages. Significantly for our purposes, in sustaining her claims as stating proper causes of action, the federal district court described her first claim as a claim seeking damages for the violation of her right to 
The original legislative anathematizing of Darwin from all of public education in Tennessee, we recall, was sustained in 1927 on the masterservant view of teachers in public schools. Indeed, in Scopes, the Tennessee Supreme Court held that in respect to tax-supported publicly administered schools and universities ${ }^{252}$ the state was simply "unhampered" by the fourteenth amendment in deciding what was to be taught by those whom it paid. By 1968 and Epperson, however, as we have already noted, the decisional law of the first amendment had dramatically changed. The strong protection of professional academic freedom within public universities and also in some measure in ordinary public schools had come to be accepted in the Court, reported in its own usages of academic freedom beginning in the 1950s, in the course of holding invalid a large number of state restrictions chilling professional teaching and research. Epperson itself vindicated that freedom in assuring a high school biology teacher that she could address Darwin in her classroom, despite the state's legislated ban. ${ }^{253}$

Even so, despite the Court's decision in Epperson, the ancient contest had not yet run its course. In 1982, the Louisiana legislature enacted a true Hobson's choice. If natural science were taught, then the teacher must teach "creation-science" 254 as well. Teachers could be relieved of the duty to

\footnotetext{
"academic freedom." (Her other claim sought damages for a violation of her right to due process, that is, for failure to provide a fair hearing before the complaints against her were acted upon.) The court of appeals agreed and likewise described the school board's action as one violating her "academic freedom." Stachura v Truszkowski, 763 F2d 211, 215 (6th Cir 1985). It is just this point that makes the case appropriately mentionable here: the Supreme Court also used the same term unexceptionably in describing her right. See, for example, id at 302, 309 (use of the term "academic freedom"). Stachura is thus a helpful case, marking the identification of teaching freedom-academic freedom-in first amendment law.

But the matter is not dwelt upon here, because the case was accepted for review in the Supreme Court only to consider a different point: not to decide whether Stachura's academic freedom was protected by the first amendment, but, granting that it was, to determine how damages were to be measured when it is violated by a local school board and its members. The Court agreed that every form of damage to Stachura (including mental anguish, damage to reputation, lost income and/or lost teaching opportunities) could figure in the jury's award, including punitive damages as well. It rejected the idea, however, that additional damages could be awarded on some jury divination of the intrinsic money worth of a constitutional right per se, an award the district court had allowed. The case, though a fair argument can be made that such an award is not inappropriate, is nonetheless unremarkable in its treatment of that feature of claiming damages.

252. Recall that the Tennessee statute involved in Scopes and the Arkansas statute involved in Epperson applied to all public colleges and state supported universities as well as to public schools. See notes $14-18$ and accompanying text.

253. As we observed, see notes 153-67 and accompanying text, the Court held that insofar as the banishment of Darwin from the public school (or university) was done to serve interests of a dominant religion, it was invalid under the first amendment on that account. Nevertheless, Epperson also stood for a stronger rationale. The concurring opinion by Justice Stewart, as we noted, was not restricted to a limited establishment clause rationale. In Pico, moreover, Epperson was identified with Keyishian and other academic freedom cases in the Supreme Court. See, for example, 457 US at 853. Justice Brennan also described Epperson as a case affirming the duty of courts to intervene where "essential to safeguard the fundamental values of freedom of speech and inquiry." Pico, id at 870 , quoting Epperson, 393 US at 104.

254. "Creation-science" was defined in the statute itself as a belief regarding origins, whether of chemical elements, galaxies, organisms, species (including man) and all else, that they "were created ex nihilo and fixed by God." See Creationism Act, La Rev Stat Ann § 17:286.1-286.7 (West 1982). See also Aguillard, 482 US at 596 ("“T] he largest proportion of superintendents interpreted creation science, as defined by the Act, to mean the literal interpretation of the Book of Genesis.").
} 
provide instruction in "creation-science," that is, only by abstaining from teaching what the legislature called "evolution-science." The choice, therefore, was to teach each with the same vigor and attention as the other, or to teach neither.

The case challenging the Louisiana act was brought in federal district court by a coalition of teachers, parents, and students. That court, as well as the court of appeals, meticulously reviewed the legislation, and both concluded that the actual point of the act was to regulate public school curricula strictly in behalf of religious interests. The act plainly meant to compel teachers either to stay away from discussing evolution ${ }^{255}$ or, failing that, to offer Bible explanations (called "creationism") as part of ordinary science, to be inculcated as of equal validity. The court of appeals struck the act on the same basis as the Arkansas statute had been held invalid in Epperson, that is, as a violation of the establishment clause. The Supreme Court agreed. ${ }^{256}$ In doing so, it added that nothing in its decision should be taken to "imply that a legislature could never require that scientific critiques of prevailing scientific theories be taught." 257 But it also registered its firm agreement with the lower courts that this act was not an act of that permissible sort.

In deciding Aguillard as it did, moreover, the Court also expressly addressed the meaning of academic freedom in public education. It undertook to do so because the Louisiana act purported on its face to have been enacted not to restrict but rather to protect academic freedom-the academic freedom of students. ${ }^{258}$ In response, noting how the act was meant to work concretely, and agreeing with the elaborate court of appeals' review of the very question of how academic freedom would in fact be affected, Justice Brennan quite unremarkably concluded: "The Act actually serves to diminish academic freedom by removing the flexibility to teach evolution without also teaching creation-science even if teachers determine that such curriculum

255. The principal sponsor of the law expressly stated as his own strong preference that teachers say nothing, thus achieving the effect of the law that was invalidated in Epperson. See references and quotations at 482 US at 587.

256. Aguillard $v$ Treen, 634 F Supp 426, 428 (ED La 1985) aff d, Aguillard v Edwards, 765 F2d 1251 , 1257-58 (5th Cir 1985); see 482 US at 593-94 (discussion by Justice Brennan). See also 482 US at 602 (Powell concurring, noting that the material expected to be used in teaching "creation-science" was expected to come essentially from the Bible as the written word of God, and from materials supplied by "research" centers in which membership itself, however, required that "a member must accept 'that the account of origins in Genesis is a factual presentation of simple historical truth.' "); id at 609 (White concurring) ("[T]he teaching of evolution was conditioned on the teaching of a religious belief. Both courts concluded that the state legislature's primary purpose was to advance religion and that the statute was therefore unconstitutional under the Establishment Clause.").

257. Id at 593 .

258. The effort of the Louisiana legislature to describe the act in these terms, moreover, is itself extremely instructive of the extent to which the legislature was aware how much conditions had changed since Scopes. Sixty years earlier, there would have been no need at all to explain or to account for whatever the legislature decided on such matters. (That, after all, was the essence of Scopes.) Now, however, given the changes in constitutional doctrine and the virtual certainly of a first amendment challenge, there was felt need to say something to put a proper face on the matter at hand. Choosing the explanation of solicitude for "student academic freedom" (learning freedom) was the best thought the legislature had. 
results in less effective and comprehensive science instruction."259 The court of appeals had taken the same approach, namely that "[a]cademic freedom embodies the principal that individual instructors are at liberty to teach that which they deem to be appropriate in the exercise of their professional judgment. . . Although states may prescribe public school curriculum concerning science instruction ... the compulsion inherent in the Balanced Treatment Act is, on its face, inconsistent with the idea of academic freedom as it is universally understood." 260 The Act, in brief, actually denied one kind of academic freedom to students insofar as it denied them learning freedom in the specific sense of access to and the benefit of each teacher's best professional, good faith judgment, understanding, and skills. It operated in its own way as the Act reviewed and held invalid in Baggett $v$. Bullitt. ${ }^{261}$ It also operated in the same manner here as another statute would operate were it to require that one teaching astronomy either propose no science descriptions at all or propose Ptolemaic (earth-centered) models as viable science alternatives to Copernican ideas, that is, to require "balanced treatment" of earth-centered astronomy for the same reason as "creation-science" was required here (to confirm "God's plan" according to the Bible).

To be sure, Aguillard was not unanimous and it did divide the Supreme Court, albeit not by any very close vote. What is more useful about Aguillard, as a fair way of completing this unhurried review of academic freedom and the first amendment, however, is not anything in the division of the Court. ${ }^{262}$ Nor is it anything that separates it or its useful observations on the meaning and content of academic freedom from its discussion and decisions in Sweezy, Baggett, Keyishian, Ewing, Pico and others that lend strong encouragement and support to academic freedom, whether in universities or in public schools. It is useful, rather, because overall its treatment of that freedom is in keeping with these other cases and because it, too, tends to report a far better understanding of the first amendment imperatives for academic freedom than characterized the empty doctrines of American constitutional law when Scopes was a teacher in Tennessee. Today, on the 50th anniversary of the Joint Statement of Principles and the 200th anniversary of the Bill of Rights, despite Aguillard, it would still be quite incorrect to suggest that the protection of academic freedom is now reasonably secure. Assuredly it is not. Still, a

259. 482 US at $586 \mathrm{n} 6$. See also discussion, id at 588-89. The court of appeals had taken the same approach, namely, that

[a]cademic freedom embodies the principle that individual instructors are at liberty to teach that which they deem to be appropriate in the exercise of their professional judgment. . . Although states may prescribe public school curriculum concerning science instruction ... the compulsion inherent in the Balanced Treatment Act is, on its face, inconsistent with the idea of academic freedom as it is universally understood.

$765 \mathrm{~F} 2 \mathrm{~d}$ at 1257.

260. 765 F2d at 1257.

261. 377 US 360; see notes 115-19 and accompanying text.

262. The case came into court untested in actual application, enabling Scalia (for himself and Chief Justice Rehnquist) to suggest possibilities of legislative face-saving interpretation, that is, interpretations as might not impose more than trivially upon those subject to its "balanced treatment" provisions, according to which it could then be sustained. 
[Vol. 53: No. 3

number of things have come out nearly right, and the jurisprudence of the first amendment is vastly better than it once was. 